\title{
“Zorlayıcı Diplomasi”nin İzleri: Osmanlı Devleti’nin Makedonya'da Uluslararası Bir Malî Kontrol Mekanizması Kabul Etmeye Zorlanması (1905)
}

\section{Traces of Coercive Diplomacy: Forcing The Ottoman Empire to Accept an International Machinary of Financial Control in Macedonia (1905)}

\section{Metin Ünver* (1)}

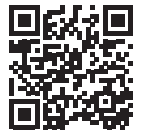

"Doç. Dr., İstanbul Üniversitesi, Edebiyat Fakültesi, Tarih Bölümü, İstanbul, Türkiye

\section{ORCID: M.Ü. 0000-0001-7417-3404}

Sorumlu yazar/Corresponding author: Metin Ünver,

İstanbul Üniversitesi, Edebiyat Fakültesi, Tarih Bölümü, İstanbul, Türkiye

E-posta/E-mail: munver@istanbul.edu.tr

Başvuru/Submitted: 08.07.2020

Revizyon Talebi/Revision Requested:

15.07.2020

Son Revizyon/Last Revision Received:

20.07.2020

Kabul/Accepted: 20.07 .2020

\section{Atıf/Citation:}

Unver, Metin. "'Zorlayıcı Diplomasi"nin İleri: Osmanlı Devleti'nin Makedonya'da Uluslararası Bir Malî Kontrol Mekanizması Kabul Etmeye Zorlanması (1905)." Tarih Dergisi - Turkish Journal of History, 71 (2020): 347-406.

https://doi.org/10.26650/TurkJHist.2020.018
ÖZ

Osmanlı Rumeli'sindeki Selanik, Manastır ve Kosova vilayetlerinde, Avusturya ve Rusya'nın denetiminde uygulamaya konulan reform programlarının başarısız olduğunu düşünen İngiltere'nin başını çektiği Büyük Devletler içinden bir grup, bu başarısızlığın öncelikle malînedenlerden kaynaklandığına inanıyordu. Bundan dolayı Makedonya olarak bilinen bölgede uluslararası bir malîkontrol mekanizması kurulmasını gündeme getirmişlerdi. Osmanlı Devleti yabancı uzmanlardan oluşan bir Maliye Komisyonu şeklinde düşünülen bu uygulamaya, bağımsızlık ve hükümranlığı zarar gördüğü gerekçesiyle uzun süre ve kararlı bir şekilde karşı çıkmıştır. Bu makalede, Makedonya'da kurulmak istenilen uluslararası malî kontrolü kabul ettirebilmek için, Büyük Güçlerin Osmanlı Devleti'ne uyguladıkları zorlayıcı diplomasinin izleri aranmakta ve konu bu pencereden ele alınmaktadır.

Anahtar sözcükler: Zorlayııı Diplomasi, Makedonya Meselesi, Osmanlı Devleti, Bahriye Nümayiş̧i, Uluslararası Mali Kontrol, Büyük Güçler

\section{ABSTRACT}

A group among the Great Powers leaded by England considered that the failure of the reform programs that were implemented under Russian and Austrian control in the provinces of Thessaloniki, Bitola and Kosovo in the Ottoman Rumelia stemmed from the financial reasons. Therefore, they came up with the idea that there should be installed an international machinery of financial control in the Macedonia region. For this purpose, it was envisioned a Financial Commission consisting of foreign experts to be founded. Ottoman Empire firmly resisted this demand for a relatively long time arguing it impaired her independence and sovereignty. In order to persuade the Ottoman government means of coercive diplomacy was applied. This article looks for the traces of coercive diplomacy utilized against the Ottoman Empire in order to persuade her to accept the establishment of an international financial control and deals the subject in this perspective.

Keywords: Coercive Diplomacy, Macedonian Problem, Ottoman Empire, Naval Demonstration, Great Powers, International Financial Control 
Son dönem Osmanlı tarihinin ciddi bir anlaşmazlık ve istikrarsızlık kaynağı olan Balkanlarda, neredeyse her milletin elde etmek için silaha başvurduğu üç Osmanlı vilayetini içine alan Makedonya, 1905 yılında bir kez daha uluslararası kamuoyunun ilk gündem maddeleri arasında yer almıştır. Bölgede uzun süredir uygulanmakta olan, Avusturya ve Rusya'nın belirleyici olduğu reformları yetersiz gören İngiltere'nin başını çektiği bir grup ülke, ardı ardına uygulamaya konulan reform programlarının başarısızlığının arkasında malî sorunlar olduğunu ileri sürerek, bölgenin maliyesinin yabancı memurların kontrolüne verilmesi teklifinde bulunmuşlardı. Osmanlı Devleti egemenlik ve hukuk açısından kabul edilemez olarak nitelediği bu teklifi reddedince uzun soluklu ve sert bir diplomatik mücadele başlamıştı. Bu mücadelenin son aşamasında ise taleplerini kabul ettirmek isteyen Büyük Güçler, Osmanlı Devleti'nin diplomatik olarak zorlanması gerektiğini, bunun da en güçlü şekilde bir bahriye nümayişi (donanma gösterisi) yapılarak mümkün olacağını düşünmüşlerdi. Geçmişteki benzer tecrübeler bu düşüncelerinin isabetli olduğuna inanmaları için önemli göstergelerdi.

Bu çalışmada ilk olarak zorlayıcı diplomasinin tanımı, dönemin uluslararası ilişkiler ve hukuk anlayışına göre sınırları ve içeriği üzerinde durulacak, akabinde Makedonya meselesi genel hatlarıyla verilerek, bölgenin üyelerini Büyük Güçlerin atayacağı bir malî komisyonun kontrolüne sokulmasını kabul ettirmek için Osmanlı Devleti'ne uygulanan diplomatik baskı ve tarafların savunduğu argümanlar üzerinde durulacaktır. Sonuç kısmında ise söz konusu baskının içerik, gelişim süreci ve uygulama bakımından teorik çerçevesi modern zamanlarda çizilmiş olan zorlayıcı diplomasinin unsurlarıyla ne derece örtüştüğü değerlendirilecektir.

\section{Zorlayıcı Diplomasi}

Uluslararası ilişsilerde güç, karşı tarafın politikasını değiştirmek, onu bir karar almaya veya sunulan şartları kabule zorlamak için, diplomasinin ikna edici bir eklentisi olarak görülmektedir. Rakibin iş birliğine yatkınlığını artırmayı amaçlayan zorlayıcı diplomasinin (coercive diplomacy) iki önemli bileşeni tehdit ve sınırlı güç kullanımıdır ${ }^{1}$. Bu bakımdan zorlayıcı diplomasi askerî değil diplomatik bir stratejidir².

Zorlayıcı diplomasinin esasında sınırlı gücün kullanılması değil, kullanılabileceğinin gösterilmesi suretiyle oluşturulan tehditten yararlanarak, karşı tarafın ikna edilmesi yer almaktadır³. Soğuk savaş döneminde geliştirilen bu teori Alexander L. George tarafından kavramsallaştırılmıştır ${ }^{4}$. George'a göre tehdit, zorlayıcı diplomasi fikrinin

1 G. R. Berridge - Alan James, A Dictionary of Diplomacy, Palgrave Macmillan, New York 2001 (2. Bask1), s. 40.

2 Christer Jönsson, "Coercive Diplomacy", The Encyclopedia of Empire, Online kullanım (https://onlinelibrary. wiley.com/doi/epdf/10.1002/9781118885154.dip10402), s. 1.

3 Fuat Aksu, Türk Dış Politikasında Zorlayıcı Diplomasi, Bağlam Yayınları, İstanbul 2008, s. 22.

4 Jack S. Levy, "Deterremce and Coercive Diplomacy: The Contributions of Alexander George", Political Psychology, XXIX/4 (2008), s. 537-552. 
önemli bir unsurudur. $\mathrm{Bu}$ bakımdan rakibin kendisinden istenileni yerine getirmediği için cezalandırılacağına ikna edilmesi önemlidir. Zorlayıcı diplomasi işte bu ikna sürecinde inandırıcı ve etkili bir destek sağlar. Süreç içinde diplomatik kanalların açık olması, bilgi akışının devam etmesi, verilmek istenilen mesajın rakip tarafından alınarak, rasyonel bir bakış açısıyla doğru bir şekilde değerlendirilmesi, tehdidin etkisi ve inandırıcılığı hakkında doğru kararlar alarak, kendisinden istenileni yerine getirmenin çıkarlarına en uygun davranış olacağını görmesi zorlayıcı diplomasi kavramımın soyut çerçevesini oluşturmaktadır5.

$\mathrm{Bu}$ stratejiyi uygulayanların rakipten ne talep edileceği, talebe uyulması için bir aciliyet hissinin yaratıp yaratılmaması ve bunun nasıl olacağı, talebin yerine getirilmemesi durumunda tehdit olarak ileri sürülecek ceza türü ve bunun ikna edici, inandırıcı kılınması, yalnızca ceza tehdidine mi dayanılacağı yoksa ayrıca olumlu şartlı teşviklerin sunulup sunulmayacağı konularında karar vermesi gerekmektedir. Eğer bu son yola başvurulacaksa nasıl bir mükafat verileceğinin, talebi kabul ettirmek için nasıl bir ceza uygulanacağının da belirlenmesi lazımdır6.

George, zorlayıcı diplomasinin aslında devlet yönetiminde asırlık bir strateji olduğunu ancak daha önce sistematikleştirilmediğini vurgulamıştır. Bu bakımdan uygulanabilir bir zorlayıcı diplomasi teorisi ortaya koymak istemiştir. Böylece tehdit, ikna, olumlu teşvik ve uzlaşmanın birleştiği bir pazarlık stratejisi geliştirerek, savaşa veya kesin şekilde zorlayıcı askerî stratejilere bir alternatif oluşturmayı amaçlamıştır? ${ }^{7}$ Uygulayan tarafın çıkarlarına yönelik tehdit/eylem başladıktan sonra veya henüz tamamlanmadan hayata geçirilen zorlayıcı diplomasi, bu özelliğiyle caydırıcılıktan (deterrence) farklıdır. Zira caydırıcılıkta eylem/tehdit henüz gerçekleşmemiştir. Bununla birlikte zorlayıcı diplomasinin hedefinde karşı tarafın eylemini durdurmak veya onu eylemden vazgeçmeye ikna etmek yer alır ${ }^{8}$.

Zorlayıcı diplomaside güç kullanımı üç aşamalı olarak değerlendirilmektedir. Birinci aşama güç kullanımına yönelik bir tehdit, ikinci aşama gösteri boyutlu bir güç kullanımı, üçüncü aşama ise tam kuvvet kullanımı veya savaş olup zorlayıcı diplomasi bu aşamalardan sadece ilk ikisini kapsar. Eğer güce başvurulacaksa sınırlı sayıda, ibret verici ölçüde olması esastır. Tekrar etmek gerekirse zorlayıcı diplomasinin temelinde kuvvet kullanma tehdidiyle rakibi bir şeye ikna etmek yer alır. Tam da bu nedenle uyarılarda bulunmak, pazarlık ve müzakereler yapmak zorlayıcı diplomasinin önemli boyutlarıdır. Nota veya ültimatom vermek zorlayıcı devletin hedef devlete yönelik güç kullanma tehdidinin en ciddi ifade şeklidir 9 .

5 Aksu, Türk Dış Politikasında Zorlayıcı Diplomasi, s. 27.

6 Jönsson, "Coercive Diplomacy", s. 2.

7 Levy, "Deterremce and Coercive Diplomacy", s. 539.

8 Aksu, Türk Dış Politikasında Zorlayıcı Diplomasi, s. 24.

9 Bunun yanında zımni ültimatom, dene ve gör ve baskının aşamalı olarak artırılması zorlayıcı diplomasinin diğer stratejileridir. Aksu, Türk Dış Politikasında Zorlayıcı Diplomasi, s. 28-31. 
Zorlayıcı diplomasi stratejisinde gösteri boyutlu güç kullanımının iki şekilde olabileceği ifade edilmektedir. Bunlardan ilki ibretlik bir şekilde güce başvurulmasıdır. Bu tek seferlik veya birkaç defalık bir uygulama olup, güç kullanımı tehdit ile hayata geçirilme arasında bir seviyede tutulur. Sınırlı güç kullanımı ise bundan sonraki bir aşamadır. Tehdit ve ibretlik güç kullanımıyla verilen mesajı almadığı ifade edilerek, daha ikna edici olmak adına, talepleri yerine getirmemesi durumunda hangi sonuçlara maruz kalacağını rakibe göstermeyi hedefler. İlkinden daha fazla güç kullanılmakla birlikte ilişkiler savaş boyutuna varmaz ${ }^{10}$.

Zorlayıcı diplomasinin başarılı olma ihtimali konusunda George iki temel değişkene işaret etmiştir. Bunlar baskı uygulayan tarafın ne talep ettiği, baskı gören tarafın ise bunu kabul etmeme temayülünün ne kadar yüksek olduğudur. Bu iki değişken birbirine bağlı olup mütevazi bir talebin rakibe baskı uygulamayı kolaylaştıracağı, buna karşılık kapsamı geniş olan bir talebin rakibin direncini güçlendirerek, baskı yoluyla ikna edilmesini zorlaştıracağ söylenmektedir. Başka bir ifadeyle eğer baskının sebebi olan talep, baskıya maruz kalandan ziyade baskıyı uygulayan için daha önemliyse, baskıyı uygulayanın şansı daha fazladır. Tersi bir durumda yani talep baskıya maruz kalanın hayati bir çıkarını ihlal ediyorsa o zaman zorlayıcı diplomasinin başarılı bir şekilde uygulanması zorlaşacaktır. Bir de eğer işin başında ortaya atılan tehdit rakipte şartların kendisinden talep edilene boyun eğmesinden daha kötüye gideceği şeklinde bir korkuya yol açarsa diplomatik zorlama tesirini artıracaktır ${ }^{11}$.

\section{Osmanlı Devleti’ne Uygulanan Baskılar ve Bahriye Nümayişleri}

Osmanlı Devleti'ne karşı, erken dönemlerde savaş sırasında başvurulan bir strateji olarak devleti barışa zorlamak, lojistik ikmal hatlarını kesmek ve gemi trafiğini önlemek gibi değişen amaçlarla rakip devletler Doğu Akdeniz ve Ege Adaları'nı içine alan Boğazlara kadar olan bölgede ${ }^{12}$ çeşitli işgal ve ablukalar gerçekleştirmişlerdir. Geçmişteki bu örnekler, 19. yüzyılda uygulanan bahriye nümayişlerinin sınırları konusunda adeta rehberlik etmiştir. En önemli fark son dönemdeki uygulamaların savaş hali dışında gerçekleştirilmiş olmasıdır. Geçmişte daha çok Çanakkale Boğazı girişinde bulunan adaları veya Osmanlı sahil şehirlerini hedef alan işgal girişimi ve Boğazın ablukaya alınmasıyla İstanbul üzerinde kurulan askerî baskı ve tehdit ${ }^{13} 19$. yüzyılın özellikle ikinci yarısından itibaren, çoğunlukla yine aynı mevkileri

10 Jönsson, "Coercive Diplomacy", s. 6.

11 Jönsson, "Coercive Diplomacy", s. 3-4.

12 Değişik bir örnek olarak Koalisyon Savaşları sırasında, Osmanlı Devleti'ni Fransa’ya karşı oluşturulan ittifaka yeniden dahil edip, Rusya'ya ilan ettiği savaşa son verilmesini sağlamak isteyen İngiltere'nin İstanbul sefiri Arburthnot'un teşvikleriyle 1807 'de girişilen ve İngilizler açısından başarısızlıkla sonuçlanan İstanbul'u topa tutma hadisesinin detaylı ve heyecanlı bir anlatımı için bkz. Fatih Yeşil, "İstanbul Önlerinde Bir İngiliz Filosu: Uluslararası Bir Krizin Siyasî ve Askerî Anatomisi”, Nizâm-ı Kadîm 'den Nizâm-ı Cedîd'e III. Selim ve Dönemi, ed. Seyfi Kenan, İSAM Yayınları, İstanbul 2010, s. 391-493.

13 Girit'in Osmanlı Devleti tarafından fethi sırasında Venediklilerin Bozcaada ve Limni’yi işgal ederek boğazı ablukaya almaları hakkında bkz. Ersin Gülsoy, Girit'in Fethi ve Osmanlı İdaresinin Kurulmasl (1645-1670), Tarih ve Tabiat Vakfi Yayınları, İstanbul 2004, s. 109-119. 
hedef almakla birlikte askerî araçların fiilî silahlı çatışma olmadan kullanıldığı diplomatik bir baskı ve tehdide dönüşmüştür. Devlet güçlü olduğu dönemlerde bu tehdit ve saldırılara askerî olarak karşılık vermişken, denizlerde gücünü kaybettiği son dönemlerdeki tepkisi daha çok maruz kaldığı eylemin hukuksuzluğuna vurgu yapılan protestolarla sınırlı kalmıştır. Osmanlı Devleti'nin maruz kaldığı bu tür müdahalelere yönelik geliştirdiği hukuk odaklı savunma mekanizması ve itirazların nasıl bir karşılık bulduğu 1905 yılında Makedonya'da yaşanan gelişmeler örneğinde aşağıda ele alınacaktır.

19. yüzyıl boyunca Avrupalı büyük devletlerin yaşanan birtakım gelişmeler karşısında, kendi siyasî, ekonomik ve askerî çıkarlarını korumak adına başvurdukları zorlayıcı diplomasiye en çok maruz kalan devletlerden biri Osmanlı Devleti’ydi. Özellikle bu yüzyılın sonlarından itibaren artan emperyalist rekabete rağmen, özellikle Osmanlı Devleti'ni ilgilendiren meselelerde, Büyük Güçlerin Avrupa barışının devamı uğruna aralarındaki uyumun (concert) devamına büyük oranda riayet ettikleri görülmektedir. Avrupa uyumu nedeniyle zor durumda kalan Osmanlı Devleti bir taraftan kararlı bir duruş göstererek daha büyük yaptırımların önüne geçmeye çalışmış, diğer taraftan büyük devletler arasındaki uyumu bozmak için içlerinden birini yanına çekmeye çalışmıştır.

Büyük Güçlerin Osmanlı karasularında gerçekleştirdikleri bahriye nümayişleri Fransa'nın 1901'de Midilli Adası'nı işgali sonrası yeni ve öncekilerden çok farklı bir boyut kazanmıştır ${ }^{14}$. Akabinde beş büyük devletin savaş gemilerinden oluşan müttefik donanmanın 1905 y1lında gerçekleştirdikleri bahriye nümayişi konunun Osmanlı Devleti açısından geldiği endişe verici boyutu göstermektedir. Endişe vericidir, çünkü büyük devletler artık istedikleri tavizleri alamayıp, hoşlarına gitmeyen bir direnç veya tavırla karşılaştıklarında, kendi lehlerine olmak üzere empoze ettikleri şartları kabul ettirebilmek için Osmanlı Devleti’ne planlı ve organize bir baskı uygulamaya başlamışlardır. Osmanlı devlet adamları üzerindeki baskının artırılarak ileri sürülen şartları kabul etmelerinin hızlandırılması istendiği zamanlarda bahriye nümayişleri İstanbul'un kapısı konumundaki Boğazlara doğru genişletilmiştir.

Osmanlı devlet adamları, 19. yüzyıla girilirken Avrupa'da gelişmekte olan uluslararası hukuk konseptinden haberdardılar ve kendilerini bu hukukun bir tarafı olarak görmekteydiler. Bunun bir anlamı Avrupa ile olan ilişkilerin artık bu çerçevede şekilleneceğinin kabulü ve Avrupa tarafından yapılan fiili müdahalelerde söz konusu hukukun korumasına sığınmaya başlanmasıydı. Uluslararası hukuk bu erken dönemde Osmanlı Devleti için toprak bütünlüğünün ve varlığının bir teminatı olarak görülüyordu ${ }^{15}$.

14 Metin Ünver - Murat Hulkiender, II. Abdülhamid Dönemi Osmanlı Fransız İlişkilerinde Krizler ve Çatışmalar 1901 Hadisesi (Lorando-Tubini Meselesi), İlgi Kültür Sanat Yayınları, İstanbul 2018.

15 Mustafa Serdar Palabıyı,, "The Emergence of the Idea of 'International Law' in the Ottoman Empire before the Treaty of Paris (1856)", Middle Eastern Studies, L/2 (2014), s. 240-241. 
Zaman içinde yaşanan siyasî gelişmeler uluslararası hukuka Osmanlı bakışını değiştirecektir. Osmanlı hukukçuları yüzyılın sonlarında kaleme aldıkları devletlerarası hukuka dair eserlerde, bir devletin iç işlerine her ne bahane ile olursa olsun müdahale edilemeyeceğini açık bir dille ifade etmişlerdir. Bunun nazariyatta kesin bir esas olduğunu, ancak fiiliyatta bu esasa uygun şekilde davranıldığının iddia edilemeyeceğini de eklemişlerdir. Son dönem Osmanlı tarihinin önemli hukukçularından, Mülkiye ve Hukuk Mektebinde hocalık yapmış Ali Şehbaz Efendi ${ }^{16}$ bazı nazariyatçıların, güç sahibi devletlerin zaaf halinde bulunan devletlere taarruz etmesini meşru göstermek için birtakım mahirane mütalaalar ileri sürdüklerini, bazı durumlarda bir devletin içişlerine müdahalenin caiz olduğunu ispata kalkıştıklarından şikâyet etmiştir. Sonrasında diplomatik ve askerî olmak üzere ikiye ayırdığı müdahalenin (intervention) devletin bağımsızlık hakkına saldırı olduğunu ve siyasî veya silahlı hiçbir müdahalenin caiz olmadığını bir kez daha vurgulamıştır. Bu teorik ifadelerin fiiliyatta bir ehemmiyeti olmadığını itiraf eden Ali Şehbaz Efendi, bunun sebebi olarak devletler arasındaki muamele ve ilişkilerde hiçbir zaman kesin kaidelerinin olmamasını göstermekteydi ${ }^{17}$. Bu konu karşısında Osmanlı hukukçularının durumu ile devlet adamlarının durumu farklı değildir. Bu dönemde Osmanlı Devleti'ne yönelik müdahaleleri bir hükümranlık hakkı ihlali olarak gören Osmanlı devlet adamlarının bu itirazlarına hak veren muhataplar bulduklarını söylemek zordur.

Modern uluslararası hukuk mekanizmalarının gelişmesinden önceki dönemde Büyük Güçler (Düvel-i Muazzama) kendilerini cezalandırıcı bir üst otorite olarak görmekteydiler. Henüz bir uluslararası hukuk mekanizmasının bulunmadığı bu zamanda, uluslararası düzenin tesisini onlar üstlenmişti ${ }^{18}$. Dolayısıyla uluslararası bir problemde zorlayıcı bir unsur olarak diğer devletlere yönelik güç kullanılmasına karar veriyorlar; uygulamada bazen müstakil bazen müşterek harekete geçiyorlard1 ${ }^{19}$. 19. yüzyılda zorlayıcı diplomatik baskı değişik şekillerde hayata geçirilmekteydi. Bahriye nümayişi (naval demonstration) daha sık, blokaj ise çeşitli durumlarda sıkça başvurulan iki yöntemdi. Bu tür müdahalelerde günümüzdeki gibi belirlenmiş gerekçeler ve uluslararası hukuk normları 19. yüzyıl için söz konusu değildi. Uluslararası ilişkiler bakımından müdahalede bulunan devletler için bu yüzyılda gözetilmesi gereken en önemli nokta büyük devletler arasındaki güç dengesini bozacak sonuçlara yol

16 Mehmed Zeki Pakalın, Sicill-i Osmanî Zeyli, yay. haz. Gülbadi Alan, TTK Yayınları, Ankara 2008, III, s. 3338 .

17 Mufassal Hukuk-ı Düvel, Merhum Ali Şehbaz Efendi Hazretlerinin Takrir-i Âlileridir, Naşiri Mehmed Arif, İstanbul 1324, s. 187-190.

18 Yüzyıldan fazla devam eden bu uluslararası sistemin kuruluş süreci ve felsefesi hakkında bkz. Henry Kissenger, A World Restored: Metternich, Castlereagh, and the Problem of Peace, 1812-1822, Friedland Books 2017.

191856 y1lında İngiltere'nin Çin'e karşı ve 1902'de İngiltere, Almanya ve İtalya'nın Venezuela'ya karșı uyguladığı baskı hakkında bkz. Cristopher Meyer, Getting Our Way, 500 Years of Adventure and Intrigue: the Inside Story of British Diplomacy, Weidenfeld and Nicolson, London 2009, s. 124-144; Brain Stuart Mcbeth, Gunboat, Corruption, and Claims: Foreign Intervention in Venezuela, 1899-1908, Greenwood Press, Connecticut-London 2001. 
açmamaktı. Zira denge ilkesi, dönemin uluslararası politikasının adeta üzerinde tartışılamaz bir doğmasıydi ${ }^{20}$.

Yirminci yüzyıl başında bahriye nümayişlerini devletler hukuku açısından haklı bir müdahale şekli olarak gören bir anlayış gelişmiştir. Genel menfaatin korunması adına birçok devlet tarafından ortaklaşa gerçekleştirildiğine vurgu yapılarak, bu tür nümayişlerin artık devletler hukuku bakımından tamamen kabul gördüğü ileri sürülmüştür. Bu arada konunun geçmişinden bahsederken 19. yüzyılda Osmanlı Devleti'nin kendisinden ayrılarak bağımsızlığını kazanmış devletlerle olan ilişkilerde ikincisi lehine yapılan müdahalelere özellikle atıf yapıldığı görülmektedir. Bu müdahaleler bahriye nümayişlerine yol açmış, uygulamada bazen Osmanlı sahillerinin bir bölümü işgal edilmiş, zaman zaman şehirler bombalanmış ve deniz harekâtı uygulanmıştır ${ }^{21}$.

Osmanlı Devleti'ne uygulanan zorlayıcı diplomasi, tehdit eden devlet(ler)in hedef devletle çatışma riskinden değil dönemin gergin ve çok bileşenli, kutuplaşmış uluslararası düzeni nedeniyle büyük devletler arasında fazlasıyla mevcut bir çatışma riskini ortadan kaldırmak adına tercih sebebidir. Bu yüzden diplomasi taraflar arasında sonuna kadar kullanılan en önemli araç olmuştur. 19. yüzyılın son çeyreğinden itibaren uluslararası kamuoyunu meşgul etmeye başlayan Makedonya meselesi merkezinde sadece çeteler ve çatışmaların yer aldığı silahlı mücadelenin değil aynı zamanda bir diplomatik mücadelenin de konusu olmuştur.

\section{Genel Hatlariyla Makedonya Meselesi}

Makedonya Osmanlı Rumeli'sinde Selanik, Manastır ve Kosova vilayetlerinden meydana gelen bir coğrafî bölgedir. Osmanlı Devleti tarafından resmen Vilâyât-i Selâse olarak isimlendirilmiştir. Bölge etnik bakımdan Türk, Rum, Arnavut, Sırp, Ulah ve Yahudilerden meydana gelen, oldukça çeşitli bir etnik yapıya sahipti. Özellikle 1870 yılında Bulgar Kilisesi’nin Ortodoks Rum Kilisesi’nden ayrılması sonrasında Makedonya'da yoğun bir Bulgar-Rum mücadelesi başlamıştır. Makedonya’ya yönelik emelleri olan üçüncü bir devlet ise Sırbistan idi. Berlin Kongresi ve ardından yapılan sınır düzenlemeleriyle Teselya'nın Yunanistan'a verilmesi üzerine Yunanlılar, Sırplar ve Bulgarların Makedonya'ya yönelik iddiaları başlamış, üç devlet de bölgeyi topraklarına katmak için harekete geçmiştir ${ }^{22}$. Ayrıca bölgede yaşayan Ulahlardan dolayı Romanya da zaman zaman Makedonya meselesine müdahil olmuştur ${ }^{23}$.

20 Melda Sur, Uluslararası Hukukun Esasları, Beta, İstanbul 2014 (8. Baskı), s. 5.

21 Viyana merkezli Neue Freie Presse'te yayınlanan bir makalenin Osmanlı Devleti'yle alakalı olan bölümü alınarak Tanin gazetesinde çevirisi yapılmıştır. "Bahrî Nümayişlerin Tarihçesi”, Tanin, nr. 1564, 3 Ca. 1331 (10 Nisan 1913), s. 3.

22 Douglas Dakin, The Unification of Greece, 1770-1923, New York 1972, s. 160; Kemal Beydilli, "II. Abdülhamid Devrinde Makedonya Meselesine Dair”, Osmanlı Araştırmaları, IX, İstanbul 1989, s. 78.

23 Gül Tokay, Makedonya Sorunu. Jön Türk İhtilalinin Kökenleri (1903-1908), Afa Yayınları, İstanbul 1996, s. 6768; Vemund Aarbakke, Ethnic Rivalry and the Quest for Macedonia, 1870-1913, East European Monographs Distributed by Columbia University Press, New York 2003, s. 136-138. 
Daha önce Ayestafanos Antlaşması'nın Bulgaristan'a bıraktığı Makedonya'nın bir kısmı, reform yapılmak kaydıyla Berlin'de Osmanlı Devleti'ne iade olunmuştur. Berlin Antlaşması ile vilayet statüsünde düzenlenen özerk Doğu Rumeli 1885 yılında Bulgaristan tarafından ilhak edilmiştir ${ }^{24}$. Bu gelişme Makedonya'ya yönelik benzer planları olanları da cesaretlendirmiştir. Böylece Bulgaristan ile Makedonya sınır komşusu oluyordu. Bölge üzerinde hak iddia eden üç devletin aralarındaki rekabetin sonucu olan Makedonya Meselesi'nin ilk döneminde devletler eğitime, dinî ve kültürel faaliyetlere çok önem vererek, nüfuz ve propagandalarını bu şekilde yaymaya çalışmışlardı ${ }^{25}$. Bulgarlar kurdukları birçok hayır dernekleri ve kiliseler, okullaşma çalışmaları ve eksarhlık aracılığı ile bölgede etkili olmaya çalışıyorlardı. Yunanistan bir taraftan Atina'da, Helenizmin Makedonya'da yayılmasına hizmet etmek üzere kurulan birtakım dernekler, bölgedeki Yunan konsolosluğu ve Ortodoks Patrikliği üzerinden çıkarlarına uygun bir siyaset takip etmeye çalışıyordu. Aynı şekilde, özellikle Doğu Rumeli-Bulgaristan birleşmesine karşı silaha sarılan Sırbistan, bu savaştan mağlup çıkması sonrasında Makedonya'daki menfaatlerini Yunan ve Bulgar örneklerinde olduğu üzere kurduğu birtakım eğitim ve yardım dernekleri üzerinden savunmaya yönelmiştir ${ }^{26}$. Büyük Güçler olarak adlandırılan dönemin Avrupalı devletleri de kendi menfaatleri çerçevesinde bu devletleri destekliyorlardı.

Bir süre sonra, bölgeyi kendi topraklarına katmak isteyen güçler arasındaki mücadele Makedonya içinde iddia sahibi her bir devlet tarafından organize ve finanse edilmekte olan çete savaşlarına dönüşmüştür ${ }^{27}$. Bu doğrultuda Bulgarlar tarafından Makedonya'da otonom bir idare elde etmek için 1893 'te Makedonya İhtilal Örgütü (İç Örgüt) ve 1895'te Yüksek Makedonya Komitesi (Haricî Cemiyet) kurulmuştu ${ }^{28}$. İç Örgüt 1898 y1lından itibaren çetecilik faaliyetlerine başlamıştı ${ }^{29}$. Özellikle Ağustos 1903 'te İç Örgüt tarafindan gerçekleştirilen ayaklanma ${ }^{30}$ Makedonya'da inisiyatifi kaybetmekte olduğunu düşünen Yunanlıları tedirgin etmişti. Bundan sonra Yunan Hükümeti de bölgeye çeteler sevk ederek, Bulgarlara karş1 silahlı mücadeleye başlayacaktı ${ }^{31}$. Sırp, Müslüman ve Arnavut çetelerin de silahlı mücadeleye

24 İşgalin gelişimi ve sonuçları hakkında geniş bilgi için bkz. Mahir Aydın, Şarkî Rumeli Vilayeti, Türk Tarih Kurumu Yayınları, Ankara 1992, s. 255-290.

25 Fikret Adanır, Makedonya Sorunu, Tarih Vakfi Yurt Yayınları, İstanbul 1996, s. 108-113.

26 Aarbakke, Ethnic Rivalry and the Quest for Macedonia, s. 61-95; Mehmet Hacısalihoğlu, Jön Türkler ve Makedonya Sorunu (1890-1918), Tarih Vakfi Yurt Yayınları, İstanbul 2008, s. 44-45.

27 Dakin, The Unification of Greece, s. 159-170; Adanır, Makedonya Sorunu, s. 118-144; Hasip Saygil1, "Rumeli Müfettişliği Döneminde (1902-1908) Makedonya'da Yunan Komitecileri ve Osmanlı Devleti”, Güvenlik Stratejileri, 21, İstanbul 2015, s. 147-183.

28 Adanır, Makedonya Sorunu, s. 118-123; Mahir Aydın, "Arşiv Belgeleriyle Makedonya'da Bulgar Çete Faaliyetleri”, Osmanlı Araşttrmaları, IX, İstanbul 1989, s. 209-234.

29 Hacısalihoğlu, Jön Türkler ve Makedonya Sorunu, s. 52.

30 Ayaklanma için bkz. Adanır, Makedonya Sorunu, s. 192-213.

31 İpek Yosmaoğlu-Turner, The Priest's Robe and the Rebel's Rifle: Communal Conflict and the Construction of National Identity in Ottoman Macedonia 1878-1908, Princton Üniversitesi Yayımlanmamış Doktora Tezi, 2005, s. 56; Dakin, The Unification of Greece, s. 166-167. 
dahil olmasıyla bölgede sürekli bir çatışma ortamı ve terör havası hakim olmaya başlamıştır. Makedonya'da alan genişletmek isteyen Yunanistan'ın, Ulahları Ortodoks Patrikliği içinde asimile etme çabasına bir reaksiyon olarak Ulahların Bulgar Eksarhlığı'na yakınlaşması kiliseler arasında ciddi bir çatışmaya neden olmuş, bir süre sonra Rum baskıları karşısında kendilerini savunmak isteyen Ulahların da komiteler kurmasıyla sonuçlanmıştır.

Komitelerin silahlı eylemleri yüzünden bölgede tırmanan tansiyon ve istikrarsızlık meseleyi sık sık uluslararası kamuoyunun gündemine getirmekteydi. Böyle bir sürece girilmesinde özellikle 1901 yılında Amerikalı bir rahibin ve asistanının kaçırılmas1 ${ }^{32}$ ve 1902 sonbaharında Makedonya'nın doğusunda çıkan bir isyan etkili olmuştu ${ }^{33}$. Berlin Antlaşması'na taraf olan devletler Osmanlı Devleti'ni bölgede reform yapması konusunda sıkıştırmaktaydılar. Bu bakış açısına göre hayata geçirilecek reformlar bölgedeki şiddet ve terör eylemlerini azaltabilirdi. Nitekim Osmanlı Devleti bölgede yeni bir mülkî yapılanmaya giderek, Selanik, Kosova ve Manastır'ın Vilâyât-i Selâse adı altında organize edilmesine karar vermiştir ${ }^{34}$.

Berlin Antlaşması'nın 23. maddesinde, Osmanlı Devleti'ne iade edilen Makedonya bölgesinde reform yapılması kabul edilmişti. Söz konusu 1slahatta Girit Adası örnek alınacakt ${ }^{35}$. Nitekim Avusturya ve Rusya Makedonya'da reform yapılması için harekete geçmişlerdir. Onlardan önce II. Abdülhamid bölgeye yönelik reformlar yapılması için bir komisyon kurulmasını emretmişti. Osmanlı Devleti’nin öngördüğü iyileştirmeler sadece Selanik, Kosova ve Manastır'ı değil, Yanya, İşkodra ve Edirne'yi de içine alacak şekilde Rumeli'deki tüm topraklara yani, başına Hüseyin Hilmi Paşa'nın getirildiği Rumeli Genel Müfettişliği'ne dahil edilen tüm bölgeye yönelik olarak düşünülmüştü ${ }^{36}$. Programın tüm Rumeli'de uygulanmak istenmesi Bulgarların muhalefetine ve tekliflere karşı çıkmalarına yol açmıştır ${ }^{37}$. Bunun üzerine Rus ve Avusturya sefirleri Osmanlı reform programına bazı eklemeler yaparak, Viyana Reform Programı olarak bilinen öneriyi Şubat 1903'te Osmanlı Devleti'ne sunmuşlardır.

32 Mahir Aydın, "Makedonya Meselesi ve Amerikalı Rahibenin Kaçırılması", Osmanlı Araştırmalarl, XIII, İstanbul 1998, s. 239-258.

33 Julian Brooks, “A “Tranquilizing” Influence? British "Proto-Peacekeeping” in Ottoman Macedonia 19041905”, Peace and Change, XXXVI/2 (2011), s. 173.

34 Stanford J. Shaw - Ezel Kural Shaw, History of the Ottoman Empire and Modern Turkey, II, Cambridge University Press, London-New York-Melbourne 1977, s. 209-210.

35 Beydilli, "Makedonya Meselesine Dair", s. 81; Kaya Bayraktar, Makedonya Sorunu ve Uluslararası Malî Komisyon (1902-1909), Birleşik Yayınevi, Ankara 2011, s. 23.

36 Adanır, Makedonya Sorunu, s. 167-169; Yosmaoğlu-Turner, The Priest's Robe and the Rebel's Rifle, s. 49; Emin İsmail Altınkaya, Hüseyin Hilmi Paşa'nın Hayatı ve Devlet Adamlı̆̆l (1855-1923), Akdeniz Üniversitesi Sosyal Bilimler Enstitüsü Yayımlanmamış Doktora Tezi, Antalya 2018, s. 83.

37 Osmanlı Devleti tarafından teklif edilen programın detayları için bkz. Beydilli, "Makedonya Meselesine Dair", s. 86-87; Yosmaoğlu-Turner, The Priest's Robe and the Rebel's Rifle, s. 49-50; Altınkaya, Hüseyin Hilmi Paşa, s. $86-89$. 
Viyana Programı Makedonya’yı oluşturan Selanik, Kosova ve Manastır vilayetlerine bir genel müfettiş atanması, bölgedeki jandarma ve polis kuvvetlerine Hristiyanların da kabul edilmesi ve yabancı uzmanların istihdamı, bütçede ve hukukî sahada 1slahat yapılması ve genel af ilan edilmesi maddelerini içermekteydi. Nitekim kısa bir süre içinde bu programın başarısız olduğu görülecekti ${ }^{38}$. Bulgar İç Örgüt'ü tarafindan 2 Ağustos 1903 'te Manastır'da başlatılan ve İlinden İsyanı olarak bilinen terör olaylarından en çok zararı örgütün kendisi görmüş ve ciddi oranda güç kaybetmişti ${ }^{39}$. Daha da önemlisi, her ne kadar İlinden İsyanı Avrupa kamuoyunda Makedonya'daki gelişmelere yönelik sempati uyandırmış ve bunun neticesinde bölgeye yardım komiteleri gönderilmiş ise de isyancıların beklediği gibi bölgeye otonomi verilmesi için uluslararası bir müdahaleye yol açmamıştı. Ancak yapılan reformların yetersiz olduğu yönünde bir görüş oluşarak, yine Avusturya ve Rusya'nın öncülüğünde olmak üzere yeni bir reform programı teklif edilmiştir ${ }^{40}$. Osmanlı Devleti, ilk başta reddettiği reform programını baskılar üzerine 1903 Kasım'ında kabul etmek zorunda kalmıştı ${ }^{41}$.

Mürzsteg Programı'nın Viyana Programı'ndan farklı olarak getirdiği en önemli yenilik, Avusturya-Macaristan ve Rusya'ya programının gidişatını tayin edecekleri sivil memur vasıtasıyla doğrudan gözlemleme imkanı sağlamasıydı2 ${ }^{42}$ Berlin Antlaşması'nı imzalamış olan diğer devletler de söz konusu uygulamaya katılmaya davet edilmişler ve kısa sürede Makedonya'nın çeşitli bölgeleri söz konusu devletlerin denetimine bırakılmıştı ${ }^{43}$. Kendilerine ayrılan bölgelerde jandarma kuvvetlerinin eğitimi ve bölgedeki siyasî ve askerî gelişmeleri izlemekle yükümlü olan devletlerden İtalya Manastır'1, Avusturya Üsküp'ü, Rusya Selanik'i, Fransa Serez'i ve İngiltere Drama Sancağı'nı denetleyecekti. Almanlar ise sadece Selanik polis okuluna bir subay göndermişlerdi ${ }^{44}$. Bu şekliyle Mürzsteg Programı’nın önceliğini bölgede istikrar ve güvenliğin sağlanması oluşturuyordu.

Bu dönemde Rumeli’nin malî durumu oldukça kötüydü. Bölgede sürekli hale gelen asayişsizlik ve karışıklıklar nedeniyle hazırda çok sayıda asker bulundurulması, ayrıca

38 Aarbakke, Ethnic Rivalry and the Quest for Macedonia, s. 105-107; Yosmaoğlu-Turner, The Priest's Robe and the Rebel's Rifle, s. 50-51; Mufassal Osmanl Tarihi, VI, metin ve ilaveler: Midhat Sertoğlu, İstanbul 1972, s. 3392; Bayraktar, Makedonya Sorunu, s. 64-68.

39 Hacısalihoğlu, Jön Türkler ve Makedonya Sorunu, s. 116. İsyan hakkında geniş bilgi için bkz. Adanır, Makedonya Sorunu, s. 172-213.

40 Tokay, Makedonya Sorunu, s. 46-48.

41 Adanır, Makedonya Sorunu, s. 216-217; Julian Brooks, Managing Macedonia: British Statecraft, Intervention, and 'Proto-peacekeeping' in Ottoman Macedonia, 1902-1905, Simon Fraser University, Faculty of Arts and Social Sciences, Department of History, Yayımlanmamıs Doktora Tezi, British Columbia (Kanada), 2014, s. 567.

42 Aarbakke, Ethnic Rivalry and the Quest for Macedonia, s. 114; Hacisalihoğlu, Jön Türkler ve Makedonya Sorunu, s. 109.

43 Bu çerçevede Drama İngilizlerin kontrolüne verilmiş ve 1904 ilkbaharından itibaren burada bir taraftan yerel jandarma kuvvetlerini eğitirken diğer yandan siyasî ve askerî gelişmeleri gözetlemişlerdir. İngilizlerin Drama'daki faaliyetleri için bkz. Brooks, "British "Proto-Peacekeeping"”, s. 172-190.

44 Brooks, "British Proto-Peacekeeping", s. 175; Aarbakke, Ethnic Rivalry and the Quest for Macedonia, s. 117; Mufassal Osmanlı Tarihi, VI, s. 3393. 
vergilerin tam olarak tahsil olunamaması gibi sebeplerden ötürü Selanik, Kosova ve Manastır vilayetleri sadece kendi gelirleriyle, bölgede görevli mülkî-askerî personelin maaş ve diğer giderlerini karşılayacak durumda değildi. Bunun haricinde redif taburlarının da silahaltında bulunması ödenen maaş miktarını yüksek meblağlara çıkarmaktaydı ${ }^{45}$. Bu arada Mürzsteg Programı, Osmanlı Devleti'ne birtakım malî yükümlülükler getiriyordu. Bunlar göç etmiş Hristiyanların eski yerlerine tekrar iskanı, isyanda zarara uğramış Hristiyanlara tazminat ödenmesi, zarar görmüş köy, ev ve kiliselerin tamir ve yeniden inşası, ayrıca tahrip olan yerlerin Hristiyan sakinlerine bir sene vergi muafiyeti tanınmasıyd $1^{46}$.

\section{İngiltere’nin Makedonya’ya Yönelik Siyasi Tavrını Değiştirmesi}

İngiltere'de kamuoyu hükümetlerin başka birçok konuda olduğu gibi Osmanlı Devleti'ne dair meselelerdeki karar alma süreçlerinde de belirleyici olmuştur. Bununla birlikte zamanla karş1lıklı bir ilişki gelişmiştir. Aşağıda bahsedilecek olan Balkan Komitesi ve diğer bazı sivil toplum hareketleri İngiliz hükümetinin Balkan politikasını desteklemeyi bir vazife sayarken, İngiliz hükümeti de değişik zamanlarda Makedonya reformları konusundaki faaliyetlerini uygulamaya koyma noktasında kamuoyunun desteğini aramıştır. İhtiyaç duyduğu durumlarda hükümet, ülkedeki çeşitli sivil toplum kuruluşlarını ve diğer kamuoyu araçlarını Türklerin "kötü yönetimi, uygulamaları ve zulümlerine" karşı protestolarda bulunmak üzere harekete geçirmiştir. Özellikle Henry Charles Keith Petty-Fitzmaurice veya daha bilinen adıyla Lord Henry Lansdowne’un 1905 yılı sonuna kadar Dışişleri Bakanı olduğu Arthur James Balfour'un başbakanlığındaki Muhafazakar hükümet döneminde takip edilen daha faal diplomasi sırasında bu durum bariz bir hal almıştır ${ }^{47}$.

20. yüzyıla girilirken Balkan Komitesi İngiltere'nin Balkanlar politikasının şekillenmesinde ağırlığını giderek artıran önemli bir kuruluştur. Balkan Komitesi'ni belki de en iyi tanıyan, Komitenin iddialarına karşı birçok reddiye yazmış Halil Halid Bey’dir. Ona göre Balkan Komitesi Makedonya'daki karışıklıklar alevlendiği sırada ortaya çıkmış, ara sıra Anadolu'daki Ermenilere teveccüh gösterir gibi olmakla beraber asıl faaliyetlerini Balkan hükümetlerinin yararına ve Osmanlı ülkesinin aleyhine yoğunlaştırmıştır ${ }^{48} .1903$ yazında

45 Maliye Nezareti'nin 7 Ocak 1903 tarihli hesaplarına göre Rumeli vilayetlerinin senelik maaş giderleri yaklaşı iki milyon lira tutmaktaydı. 13 Şubat 1904 tarihli hesaplara göre Manastır, Selanik ve Kosova vilayetlerinin maaş ve mahalli harcamalarından dolayı açığı sekiz yüz bin liranın üzerinde gerçekleşmekteydi. Bir yıl sonra 8 Şubat 1905 tarihinde üç vilayetin bütçe açığı beş yüz altmış bin liranın üzerindeydi. Beydilli, "Makedonya Meselesine Dair", s. 88-89, 99. Ayrica bkz. Steven W. Sowards, Austria's Policy of Macedonian Reform, Columbia University Press, New York 1989, s. 51.

46 Beydilli, "Makedonya Meselesine Dair", s. 96; Bayraktar, Makedonya Sorunu, s. 74-77.

47 Bozhidar Samardjiev, "On the Role of Public Opinion in Great Britain Regarding the Reforms in European Turkey and the Idea of Autonomy of Macedonia in British Middle East Policy (1903-1908)", Etudes Balkaniques, 2002/2, Sofia 2002, s. 16.

48 Halil Halid, "İngiltere'de Balkan Komitesi ve Meslek, Mazi ve Müstakbeli”, Strat-ı Müstakim, nr. 99 (15 Temmuz 1326), s. 360. 
kurulmuş olan ve İngiliz hükümetinin genel itibariyle Balkanlar, özelde ise Makedonya politikasının şekillenmesinde büyük etkileri görülen Balkan Komitesi'nin üyeleri arasında oldukça önemli siyasetçiler, yazarlar, aktivistler, gazeteciler kısacası İngiliz siyaset mahfillerinde söz sahibi birçok isim yer alıyordu. Bunlardan Noel and Charles Buxton kardeşler, H. N. Brailsford, James Bauchier ve G. Evans Komitenin kurulmasında başat bir rol oynamışlardır. Bu kurucu ekibin istekleri sonucunda önemli politikacı Lord James Bryce Komitenin başkanlığını üstlenmiştir. Onun başkanlığı sayesinde Balkan Komitesi liberal isimlerin, devlet adamlarının, gazeteci, yazar, tarihçi ve din adamlarının ilgisini kazanmıştı ${ }^{49}$.

Balkanlarda özellikle Makedonya'ya ait meseleler 1897 y1lından beri Avusturya-Rusya tarafindan belirlenen politikalar etrafinda şekillenmekteydi. Yukarıda bahsedildiği üzere, esaslarını bu iki devletin oluşturduğu ve uygulamasını takip ettikleri 1903 tarihli Mürzsteg Reform Programı'nın başarısından İngiltere'de ciddi şekilde şüphe duyan bir kesim vardı ${ }^{50}$. Dahası, İstanbul'daki İngiliz diplomatları söz konusu reform programını Balkanlarda bir süre sorun çıkmasını istemeyen Rusya'nın palyatif bir adımı olarak görüyor, bölgenin gelişimine gerçek bir katkı sağlamayacağını düşünüyorlardı ${ }^{51}$. Bu bakımdan İngilizler, muhafazakar veya statükonun korunmasına yönelik olarak niteledikleri Avusturya-Rusya liderliğindeki reform projesi yerine, artan kamuoyu baskısının da etkisiyle, bu yıllarda daha radikal bir program uygulanmasını savunmaya başlamışlardı. Gül Tokay "her şeye rağmen" Avusturya-Rusya ittifakının reform programının uygulanması konusunda diğer Büyük Güçler tarafından, 1903-1905 yılları arasında serbest bırakıldığını belirtmiş; ancak özellikle Japonya ile olan savaşta Rusya'nın aldığı ciddi mağlubiyeti ve 1904 yılında varılan İngiliz-Fransız İttifakını, bölgeye yönelik İngiliz politikasının ciddi bir şekilde değişmesine yol açan önemli iki gelişme olarak nitelemiştir ${ }^{52}$.

İngiltere'nin Makedonya'ya yönelik reformlar konusunda özellikle Eylül 1903'ten itibaren köklü şekilde değişmeye başlayan bakış açısı, kamuoyunda ve yönetim çevrelerinde 1904 yılında artık ciddi bir kanaate dönüşmüştü. İngiliz hükümetinin daha faal bir rol üstlenmesi ve örneğin bölgenin özerkliğine dönük etkili adımlar atılması gibi tartışmalar sıkça ve yönetimin üst kademelerinde gerçekleştirilmekteydi ${ }^{53}$.

Viyana Reform Programı Avusturya sefiri tarafindan 17 Şubat 1903'te kendisine sunulduğunda İngiltere Dışişleri Bakanı Lord Lansdowne, programın detaylarını incelemek

49 Samardjiev, "On the Role of Public Opinion", s. 17.

50 BOA, Y.A.HUS, 486/45.

51 T. G. Otte, The Foreign Office Mind. The Making of British Foreign Office Policy, 1865-1914, Cambridge University Press, 2011, s. 279-280.

52 Tokay, Makedonya Sorunu, s. 74-75. Diğer taraftan İngiltere'nin 1899-1902 yılları arasında Güney Afrika’ya yoğunlaşması da Balkanlardan bu süre zarfında uzak kalmasının sebepleri arasında gösterilmektedir. Bayraktar, Makedonya Sorunu, s. 36.

53 Samardjiev, "On the Role of Public Opinion", s. 22-23. Bu dönemde Makedonya'da müdahale edilmesi için İngiltere hükümeti üzerinde basın faaliyetleri ve Balkan Komitesi’nin çalışmalarının detaylı ve duygusal bir anlatımı için bkz. Brooks, Managing Macedonia, s. 395-414. 
için yeterli zamanın olmadığını ileri sürerek, reformlar konusunda ileride bazı teklifler ve taleplerde bulunabileceğine işaret eden yedi maddeden oluşan yazılı bir cevap vermişti ${ }^{54}$. $\mathrm{Bu}$ yaklaşımıyla İngiltere bir taraftan reformlara bağlı olduğunu göstermiş diğer taraftan bunun şartlı olduğunu hissettirmiştir. Kısa bir süre sonra hayata geçirilen Mürzsteg Programı konusunda da böyle bir algı söz konusuydu. Yani İngiliz siyasî çevrelerinde Avusturya ve Rusya’ya söz konusu programlar dahilinde belirli süreler için yetki verildiği düşünülüyordu.

Balkan Komitesi yaptığı açıklamalarla kamuoyunda Avusturya ve Rusya'nın uzun süredir diğer devletlerden aldığ 1 vekaletle Rumeli'de giriştiği reformların başarısız olduğuna, bu iki devlete fazla kontrol verildiğine ve İtalya, Fransa ve İngiltere'nin tekrar konuya dahil olarak, bölgede daha sert yöntemlere başvurmaları gerektiğine dair kamuoyunda bir kanaat oluşturmaya çalış1yordu ${ }^{55}$.

Osmanlı Hariciyesi Rumeli 1slahatı konusunda İngiltere'de yaşanan tartışmaları hem İngiliz parlamentosu hem de basını özelinde yakından takip ve İstanbul'a rapor ediyordu. Konu hakkında sert bir tavır takınılarak İngiliz hükümetinin tek başına hareket etmesini savunan grup yanında, diğer Büyük Devletlerle birlikte hareket edilmesini, reformların devamını ve Osmanlı Devleti'ne süre verilmesini savunan bir grup da vard1 ${ }^{56}$. Sertlik taraftarları zaman zaman Osmanlı Rumeli'sine bir Hristiyan vali veya valiler tayin edilmesinin sağlanmasını İngiliz Parlamentosunun gündemine de getiriyorlard $1^{57}$.

Hükümet ise halka Makedonya meselesinde İngiltere'nin etkisinin azalmadığını anlatmak istiyordu. Tam da bu dönemde Makedonya hakkında yayınlanmış Mavi Kitap bir yönüyle bu amaca matuftur ${ }^{58}$. Dolayısıyla İngiliz kamuoyunda artık Makedonya'daki reformların başarısının Avrupa himayesine bağlı olduğuna, bölgedeki reformların ancak bir dış müdahale ile hayata geçirilebileceğine yönelik etraflıca fikirler oluşup, sistematik bir şekilde dolaşıma sokulmuştur. Bu görüşlerde Türk idaresinin reform konusuna yatkın olmadığına, Türklerin bölgedeki suiistimallerine ve kötü yönetimine, Hristiyanların çektiği çileye aşırı bir vurgu vardı. Buna mukabil Fransa, İngiltere ve İtalya'dan oluşan Batılı Güçlerin acil görülen eyleme geçme konusunda liderlik etmeleri ve bu konuda Avrupa uyumunun mutlaka sağlanması gerektiği savunulmuştu ${ }^{59}$. Böylece uzun süredir Avusturya ve Rusya'nın kontrolünde

54 Brooks, Managing Macedonia, s. 233. Söz konusu yedi madde için bkz. s. 741.

55 BOA, Y.A.HUS, 477/115, Lef 3, Londra Sefareti'nden 9 Ağustos 1904 tarihinde Hariciye Nezareti'ne gönderilen tahriratın tercümesi.

56 BOA, Y.A.HUS, 485/124.

57 BOA, Y.A.HUS, 485/15.

58 Documents Diplomatiques Français (1871-1914), 2. Série (1901-1911), Tome VIII (29 Septembre 1905-15 Janvier 1906), Paris: Ministère des Affaires Étrangères. Commission de Publication des Documents Relatifs aux Origines de la Guerre de 1914, s. 12-13; Brooks, Managing Macedonia, s. 444.

59 Arthur Ponsonby, "The Execution of Reforms: A Plea for A British Policy", The Balkan Question. The Present Condition of the Balkans and of European Responsibilities by Various Writers, ed. Luigi Villari, London 1905, s. 331-350. 
gelişen Balkan politikasının Büyük Güçlerin tamamının katılımıyla belirlenip yürütülmesi İngiltere'nin öncelikli hedefi olmuştur.

\section{Uluslararası Malî Komisyon Kurulması Teklifi ve Osmanlı Devleti’nin Kararlı Duruşu}

Osmanlı Devleti'nin uluslararası bir bahriye nümayişine maruz kalacağı gelişmeler esas itibariyle bölgenin malî sorunlarının giderilmesiyle reformların daha iyi sonuç vereceği düşüncesine sahip devletlerin, doğrudan delege tayin edecekleri bir komisyon kurarak, Makedonya üzerinde malî bir kontrol oluşturmak istemeleriyle başlamıştır.

Bu konuda ilk teklif 17 Ocak 1905'te Avusturya ve Rusya'dan gelmiştir. İki müttefik güç Osmanlı Devleti'nden Rumeli'deki üç vilayetin malî işlerinin Osmanlı Bankası'na bırakılmasını, sancak ve kaza bazında ayrı bütçeler yapılmasını istemiştir. Bölgenin maliyesi, görevlendirilecek altı müfettiş tarafından idare edilecekti. Müfettişler Osmanlı Bankası, Rumeli Genel Müfettişi ve Avusturyalı ve Rus ajan sivillerin kontrolünde olacaktı ${ }^{60}$.

Ekonomik sıkıntılar reform paketinde öngörülen, jandarma kuvvetlerinin yeniden organizasyonu gibi birçok konunun hayata geçirilmesine gerçekten bir engel teşkil etmekteydi. Osmanlı Devleti buna bir çözüm olarak Makedonya'da öngörülen reformların finansmanı için gümrük vergisinin $\% 8$ 'den $\% 11$ 'e çıkarılarak, elde edilecek gelir fazlasının kullanılmasını 15 Şubat'ta resmen teklif etmişti ${ }^{61}$.

Büyük devletlerin tamamı bölgede gerçekleştirilecek reformların maliyetini karşılamak için kaynak yaratılması konusunda hemfikir olmakla beraber, yöntem konusunda fikir birliğine sahip değillerdi. Sadece İngiltere Osmanlı Devleti’nin istediği şekliyle gümrük vergilerinin oranında bir artışa, reform sürecinin çıkmaza girmesi pahasına, karşı çıkmaktaydı. Avusturya ve Rusya, bazı şartlar dahilinde Babıali'nin teklifine sıcak bakıyordu. İki devletin bakış açısının merkezinde, sağlanacak gelir artışının tamamen Makedonya'daki reformların gerçekleştirilmesinde kullanılması yer alıyordu. Osmanlı Devleti, bağımsızlığının sınırlanması olarak değerlendirdiği bu yaklaşımı kabul etmemiştir.

Şüphesiz diğer devletlerin de bu noktada çeşitli talepleri vardı. Bunlar İstanbul'da ilgili devletlerin sefirlerinin kendi aralarında yaptığı toplantılarda değerlendirilmiştir. Diğer dört devlet gerek Berlin Antlaşması gerekse gümrük antlaşmalarına dayanarak böyle bir konuyu sadece Avusturya ve Rusya'nın kontrolüne bırakmak istememişlerdir. Ancak bölgenin malî işlerinin yürütülmesinde Osmanlı Bankası'nın mı yoksa Düyûn-1 Umumiye'nin mi seçilmesi gerektiği konusunda uzlaşamamışlardır. Akabinde Fransa'nın İstanbul'daki sefiri Ernest

60 Bayraktar, Makedonya Sorunu, s. 102-103; Abdulhamit Kırmızı, Avlonyalı Ferid Paşa. Bir Ömür Devlet, Klasik Yayınları, İstanbul 2014, s. 259.

61 Bayraktar, Makedonya Sorunu, s. 94-95. 
Constans İtalya ve İngiltere tarafından da desteklenen bir teklif sunmuştur. Bölgeye dair siyasî ve idarî konular yine Avusturya ve Rusya'nın ortak sorumluluğunda kalmak kaydıyla, maliye işleri için diğer dört devletin her biri özel ajanlar tayin edecekti. Avusturya Dışişleri Bakanı Aehrenthal teklife son halini vermiştir. Buna göre dört devlet tarafindan maliye delegesi unvanıyla tayin edilecek görevliler, konumları Mürzsteg Programı'nda belirlenmiş olup Avusturya ve Rusya tarafından daha önce atanmış ajan siviller ile birlikte bölgenin maliyesinin düzenli bir şekilde işlemesini kontrol edeceklerdi ${ }^{62}$. Nitekim Almanya, İngiltere, Fransa ve İtalya verdikleri ortak nota ile konuyu Osmanlı Devleti'ne bildirmişlerdir (8 Mayıs 1905).

Osmanlı Devleti büyük devletlerin Rumeli'deki üç vilayetin maliyesinin kontrolüne yönelik girişimine karşı, 18 maddeden oluşan bir Talimatname hazırlamıştır. Bölgenin malî işlerinin Osmanlı Bankası üzerinden yürütülmesine, maaş ve diğer ödemelerin Banka üzerinden yapılmasına imkan sağlayan düzenleme ayrıca, ihtiyaç halinde Bankanın ödemelerde yüz bin liraya kadar avans sağlamasını da getiriyordu ${ }^{63}$. Bu konuda Osmanlı Bankası ile bir anlaşma yapılmıştı. 1 Mart 1905 'te çıkan iradeyle onaylanan Talimat 14 Mart’tan itibaren uygulamaya girmiştir.

Diğer taraftan Babıali'nin herhangi bir cevap vermediği dört devlet bölgeye malî delege atama isteklerini bir adım daha ileri götürerek, bu delegeleri tayin ettiklerini haber vermişler ancak bu da reddedilmişti (29 Ağustos 1905). Babıali’nin kararlı tavrına rağmen devletlerin İstanbul'daki sefirleri, atanmış olan maliye memurlarına 1905 yılı Ekim ayı başında Selanik'te toplanma emri vermişstir. Buna dair 19 Eylül'de Babıali'ye sundukları ortak notada, devletlerin tekliflerini kabulünde yaşanan gecikmenin Selanik, Kosova ve Manastır vilayetlerinde vahim sonuçlara yol açacağını belirtmişlerdir ${ }^{64}$. Bu aslında üstü kapalı bir tehditti. Hariciye Nezareti maliye memurlarının bölgeye gönderilmesine engel olmak için yurt dışındaki diplomatik temsilciliklerine büyük devletlerin dışişleri bakanlarını ikna etmelerine dair talimat göndererek, Rumeli'de kurulması teklif olunan malî denetime karşı duruşundan geri adım atmayacağının altını çizmiştir ${ }^{65}$.

Büyük devletlerin İstanbul'daki sefirlerine 30 Eylül'de verilen aynı içerikli takrirlerde konu hakkındaki bakış açısını etraflıca ortaya koyan Osmanlı Hükümeti, Kosova, Selanik ve Manastır vilayetlerinde gerçekleştirilen malî düzenlemelerin önemini hiçbir zaman göz ardı etmediğini savunmuştu. Osmanlı Bankası ile söz konusu üç vilayetin malî işlerine dair imzalanan anlaşma bunun en açık delili idi. Yabancı malî memurlar tayinine ise iç işlerini ilgilendiren bir konuya doğrudan doğruya bir müdahale olmasından ve altı büyük devletin

62 Sowards, Austria's Policy of Macedonian Reform, s. 53-57.

63 Bayraktar, Makedonya Sorunu, s. 92-93.

64 BOA, Y.A.HUS, 493/74, Lef 3.

65 BOA, Y.A.HUS, 493/94, Lef 4. 
riayet edeceklerini resmen ve defalarca taahhüt ettikleri saltanatın hukuku ve bağımsızlığına en ağır şekilde zarar vermesi yüzünden karşı çıkmaktaydı. O zamana kadar alınmış olan tedbirler her türlü ihtiyacı karşılamaya yetmiş ve güzel sonuçlar vermiş olup, üç vilayette karışıklık çıkacağına dair endişeleri de ortadan kaldıracak mahiyetteydi. Bu nedenle Osmanlı Devleti, büyük devletlerin sefirlerinin bu türden ihtimallere dayanarak, devleti Mürzsteg Programı'nda bile açık olmayan bir tedbiri kabule zorlanmalarının sebebini hiçbir şekilde anlayamıyordu ${ }^{66}$.

Bütün bunlara rağmen, İngiltere, Fransa, İtalya ve Almanya malî temsilcileri Üsküp’e gitmek için yola çıkardıklarını Osmanlı Devleti'ne 6 Ekim tarihli ortak nota ile haber vermişlerdi $^{67}$. Babıali, bu adımı protesto ederek, bu kişileri tanımadığını ilan ve geri çağrılmalarını talep etmiştir. Diplomatik baskılar karşısında yayınladığı notada Babıali, Mürzsteg Programı'nda yer alan hükümlerin getirdiği yükümlülüklerin tamamını yerine getirdiğini, Osmanlı hükümeti için kabul edilmesi hiçbir şekilde mümkün olmayan bir proje üzerinde 1 srar edilmemesini istemiştir ${ }^{68}$. Notada Osmanlı hükümeti daha önce tayinleri prensipte kabul edilerek, görev süreleri ortaklaşa kararlaştırılmış olan mevcut ajan siviller dışında yeniden memur gönderilmesinin yapılan anlaşmalara ve devletin istiklal ve hukukuna uygun olmadığının altını bir kez daha çizmiştir ${ }^{69}$. Bu nokta, bahis konusu anlaşmazlık sürecinde Osmanlı Devleti'nin tekrar tekrar hatırlattığ gerekçedir. Encümen-i Mahsus'taki görüşmelerde bölgenin malî işlerinin Osmanlı Bankası ile yapılan mukaveleye uygun bir şekilde yürütülmekte olduğuna dikkat çekilmiştir. Bu doğrultuda gelecek senelerde karşı karşıya kalınacak masraf açığının önünü alacak tedbirler hayata geçirilecek, anlaşmanın gelecek senelerde de yürürlükte kalması için çalışılacaktı ${ }^{70}$. Anlaşıldığ1 üzere Osmanlı hükümeti kendi geliştirdiği malî uygulamaya dikkat çekerek, bunu devam ettireceği mesajını veriyordu.

Yukarıda görüldüğü üzere, büyük devletlerin bir oldubittiye getirerek, seçtikleri maliye memurlarını Üsküp'e gönderme kararına güçlü bir şekilde karşı çıkan Osmanlı Devleti, yurt dışındaki diplomatik temsilciliklerinden bulundukları ülkelerin dışişleri bakanlıkları nezdinde teşebbüste bulunmalarını istemiştir. Gelen ilk bilgilere göre bu meselede öncü bir rol üstlenmeyi arzu etmeyen Fransa, daha önce yaptığı şekilde Avusturya ve Rusya'yı takip edecektir $^{71}$.

66 "Hükûmet-i seniyye esbâb-l mesrûdeye mebnî bu meseledeki sûret-i fikr ü nazarından asla inhirâf etmemeğe kat'iyyen azm etmiş olduğundan bu bâbdaki takrîr-i sabıkasının netâyic-i muhteviyâtında sebattan gayri bir şey yapamaz ve binaen-aleyh Osmanlı memûrlarının asla tanımaya yetkili olmadıklart maliye delegelerinin Selanik'e izâmından sarf-ı nazar etmelerini sefirler hazeratından rica eyler": BOA, Y.A.HUS, 493/94, Lef 7.

67 BOA, Y.A.HUS, 494/7, Lef 3.

68 Babıali’nin sefirlere verdiği cevabî notasının Fransızca orijinali ve İngilizce tercümesi: Turkey. No. 1 (1906). Further Correspondence Respecting the Affairs of South-eastern Europe, 1906 [Cd. 2816], nr. 96, s. 61-62.

69 BOA, Y.A.HUS, 494/13, Lef 7.

70 BOA, Y.A.HUS, 494/13, Lef 1. 9 Şaban 1323 (9 Ekim 1905) tarihli sadaret tezkiresi.

71 BOA, Y.A.HUS, 493/125, Lef 2. Paris’teki Osmanlı Sefaretinin 4 Ekim 1905 tarihli telgrafi. 
Rumeli'de kurulması teklif olunan malî kontrol konusunda Büyük Güçlerin takip ettikleri politikaya dair alınmış bir mütalaa, Osmanlı Devleti'nin bu tarihlerde karşı strateji geliştirmek için çalıştığını ve farklı kaynaklara yöneldiğini düşündürmektedir. Değerlendirmeler Rumeli'de bulunan üç vilayetteki gelişmeleri takip eden ve sefïlerin düşüncelerine vakıf olan yabancı bir siyasetçiye aittir ${ }^{72}$. Bununla birlikte, ilgili belgede ismi veya imzası yer almadığından kimliği tespit edilememiştir. Bu değerlendirme baştan aşağı incelendiğinde Osmanlı Devleti'nin uygulanan diplomatik baskıya karşı takip ettiği politikayla genel itibariyle örtüştüğü görülmektedir. Konuyu çıkış noktasından itibaren ele alan mütalaada en baştan Avusturya ve Rusya'nın böyle bir malî kontrol mekanizması önerdiklerini, işin şeklinin değiştiğini anlayan Avrupa devletlerinin, konunun bu iki devletin inhisarında kalmasını uygun bulmayarak, meseleye dahil olduklarını açıklamıştır. Bu safhada mütalaa sahibi ilk iddiasını ortaya koymuştur. Avusturya ve Rusya diğer devletlerin işe karışmasını kendi menfaatleri açısından uygun bulmamış, ancak bunu da ifade edememişti. Bu bakımdan devletler dışarıdan ittifak halinde görülseler bile arka planda aralarında bir rekabet ve görüş ayrılığı bulunmaktaydı.

$\mathrm{Bu}$ iddiasını ispat etmeye çalışan mütalaa sahibine göre, Avusturya İtalya'nın bu meselede rol oynamasından memnun değildi. Aynı şekilde Rusya da İngiltere'nin öncü rolünden hoşlanmıyordu. Bu düşüncelerini açıkça ortaya koymayı kendi çıkarlarına uygun bulmayarak, söz konusu devletleri destekleme yoluna gitmişlerdi. Malî kontrol işine öncülük eden İngiltere İtalya'yı da arkasından sürükleyerek, konunun Babıli'ye kolay bir biçimde kabul ettirilebileceğini söylemişti. Almanya, Avrupa uyumunu bozmuş olmamak için bir komiser ile sürece dahil olmuştu. Keza Fransa da aynı şekilde hareket etmiştir. Hiçbiri, özellikle İngiltere ve İtalya'nın konunun basit olduğuna dair teminatlarına ciddi bir mukavemet göstermeyi uygun bulmamışlardı. Bu yüzden, önerilere Osmanlı Devleti tarafından gösterilecek beklenmedik bir mukavemet karşısında İngiliz sefiri O’Conor ve İtalya sefiri Imperiali şaşırıp kalacaktır. Zaten her iki sefirin de devletleri nezdinde çok fazla kredisi bulunmamaktadır.

Mütalaa sahibi bir de faraziye ortaya koymuştur. Malî kontrolün Osmanlı hükümetine kabul ettirilebilmesi için güce başvurmaya mecbur oldukları konusunda, bahsi geçen devletlerin aralarında bir ittifak sağlanması, ancak birçok çatışmadan sonra mümkün olabilecektir. Bu gerçekleşse bile bugünkü tekliflerinin Osmanlı Devleti tarafından kabul edilmesinden daha zararlı bir sonuç ortaya çıkmayacaktır. Hatta daha az zararlı olacaktır. Çünkü Avrupa Devletleri birkaç nota vererek bu tür tekliflerini kabul ettirebileceklerine kani olurlarsa, içlerinden biri ileride kendi çıkarı olan konulardan Osmanlı Devleti’nin bütünlüğü ve istiklaline tamamen

72 "Rumeli Vilayât-ı Şâhâne-i Selasesinin Umûrunu Ta 'kīb Eden ve Süferânın Efkârına Vâkıf Olan Ecnebi Ricâl-l Siyasiyyesinden Birinin Vilâyât-ı Selase Maliye Kontrolü Hakkındaki Beyânât ve Mütâla'âtının Harfiyyen Tercümesidir": BOA, Y.PRK.TKM, 49/35. 
dokunur istekler dayatabilecektir. Diğer devletlerin buna yönelik itirazlarının hükümsüz kalacağı da açıktır. Söz konusu devlet diğerlerinden Avrupa uyumuna ve çıkarlarını korumaya katılmalarını isteyebilecektir. Bu bakımdan, Rumeli’nin malî kontrolü hakkındaki isteklerini birçok zahmet sonunda sadece zorlayıcı bir güç kullanarak elde edecek olurlarsa, yeni taleplerde bulunmadan önce epey düşüneceklerdir. Osmanlı Devleti'nin bekasını arzu eden devletler de gösterilen bu mukavemete dayanarak, ileride gündeme gelebilecek böyle bir teşebbüse katılmaktan kaçınmak için söyleyecek söze sahip olacaklardı.

Mütalaa sahibi burada muhtemel bir soruyu daha ortaya atmıştır. Devletleri tehdide başvurmaya mecbur bırakmak, taleplerini genişletmelerine yol açabilir miydi? Kendisi bu sorunun da boş olduğunu düşünmektedir. Zira böyle küçük bir madde üzerinde ittifak kuramayan Avrupa, daha büyük konularda nasıl bir araya gelebilecekti. Böyle bir ihtimal olsaydı şimdiye kadar zaten beklenilmezdi. Zaten kendi dahili işleriyle fazlasıyla meşgul Rusya ve Avusturya diğer konularla uğraşmayı hiçbir şekilde istemezdi. Bundan dolayı, büyük ihtimalle çok ciddi bir mukavemet görmeleri durumunda, ilk kontrol projesinden feragat ettikleri gibi bu işten de feragat edeceklerdir. Mütalaa sahibi özellikle Osmanlı Devleti’nin ödemelere dair Osmanlı Bankası ile yaptı̆̆ı mukaveleyi muhafaza etmesi gerektiğine de dikkat çekmiştir.

Bu uzun mütalaada özetle, Rumeli'de bir malî kontrol mekanizması kurmak isteyen devletlerin esasında kendi aralarında tam bir ittifakın bulunmadığından hareketle, bu konuda ileri sürdükleri taleplerine kararlı bir şekilde karşı çıkılması gerektiği, böylece gelecekte bu tür taleplerin sonraki yıllarda kolayca gündeme getirilmesinin önüne geçilebileceği savunuluyordu. Bir kararlı duruş karşısında büyük devletlerin güç kullanma ihtimali de dikkate alınmıştı. Böyle bir ihtimal gerçekleşse bile doğacak zarar devletin kendisine yapılan teklifi kolayca kabul etmesi durumunda, daha uzun vadede maruz kalacağından daha az olacaktı. Sonuç itibariyle devletin bütünlüğü ve hukukunun her durumda sonuna kadar müdafaası öneriliyordu. Mütalaa sahibinin atladığı bir noktayı hatırlatmak gerekir. Bu dönemde büyük devletler, görüş ayrılığına sahip oldukları çeşitli konularda dahi daha büyük çatışmalardan kaçınmak adına, güçler arasındaki uyumu bozmamak için birlikte hareket etmeye özen göstermekteydiler.

\section{Osmanlı Devleti’ne Karşı Bahriye Nümayişinin Gündeme Gelmesi}

Osmanlı Hükümetine Maliye Komisyonu konusundaki isteklerini kabul ettirmekte ciddi sıkıntıya düşen büyük devletler, bir taraftan verdikleri notalarla Babıali üzerindeki diplomatik baskıyı artırıyor, diğer taraftan da sonuç almayı hızlandıracak alternatif yollar arıyorlardı.

Bu kapsamda İngiltere Dışişleri Bakanı Lansdowne 18 Ekim 1905 tarihinde bir dizi görüşme gerçekleştirmiştir. Öncelikle Fransa'nın Londra sefíri Paul Cambon’a Osmanlı sultanını malî 
delegeleri kabule zorlamak için atılacak adımlara dair Fransa'nın pozisyonunu sormuştur. Cambon'a Büyük Güçlerin Sultanın ret yanıtını kabul etmelerinin mümkün olmadığını söyleyen Lansdowne; buna karşılık Sultanın kafasındaki gibi büyük devletlerin aralarında bölünmüş olduğu izlenimi yaratacak bir eylemde bulunmamayı da samimi olarak istediklerini; eğer diğer tüm yöntemler başarısız olursa, baskıya başvurmak için birleşmeleri gerektiğini ifade etmiştir. Bakan, bu baskının da hassasça belirlenmiş bir yerde donanma gösterisi şeklinde olabileceğini düşünmekteydi. Cambon da işin nihayetinde birtakım önlemler alınmasını kaçınılmaz görüyordu, ancak öncelikle Büyük Güçler arasında bir ön uzlaşma sağlanmalıydı ${ }^{73}$.

Lansdowne aynı konuda müracaat ettiği Londra'daki Almanya sefiri Count Metternich ve Avusturya-Macaristan sefiri Mensdorff'un ülkelerinden henüz bir talimat alınmadıklarını öğrenmişti. Lansdowne, Mensdorff'a Avusturya ve Rusya'nın Makedonya sorununa yönelik sahip oldukları özel ilgiyi büyük devletlerin her zaman kabule hazır olduklarını gösterdiklerini, bu nedenle bu bölgenin geleceği için çok önemli olan şu dakikada takip edilecek politikanın işaretleri için söz konusu iki ülkeye bakmanın anormal olmayacağını söylemiştir. Ayrıca İngiliz hükümeti olarak Babıali üzerinde baskı kurulması için atılacak her türlü aleni adımda diğer devletlerle birlikte hareket etmeye hazır olduklarını ilan etmiştir. Mensdorff'un, kafasındaki adımların neler olduğunu sorması üzerine Lansdowne, Büyük Güçlerin taleplerine muvafakat elde etmek istediklerinde donanma gösterisine başvurmuş olduklarını, düşüncesine göre benzer bir tedbire başvurmaya mecbur kalabileceklerini belirtmiştir. Böyle bir durumda donanma gösterisinin İstanbul'da gerçekleşmesi gerekliydi. Lansdowne, Rus Sefiri ile de görüşmüş, onunla da aynı içerikli bir konuşma yapmıştır. Bu kapsamda görüştüğü İtalya'nın Londra sefiri M. Pansa'ya da İngiliz hükümetinin Türk hükümetinin "dikkafalılığının" (recalcitrance) devam etmesi durumunda atılacak adımlarda diğer güçlerle beraber hareket etmeyi arzuladığını söylemiştir ${ }^{74}$.

Görüldüğü üzere İngiltere “dikkafalı” Osmanlı Devleti’nin dize getirilmesi için güce başvurularak, bir donanma gösterisinde bulunulmasını teklif etmiştir. Sonraki gün İngiltere'nin İstanbul sefiri O'Conor Dışişleri Bakanı Lansdowne'a Rus ve Avusturya sefirlerinin hükümetlerinden talimat aldıklarını, eğer Osmanlı Devleti böyle cebrî bir müdahale olmadan malî delegelerin atanmasını kabul etmeyecekse donanma gösterisinde bulunmaya hazır olduklarını bildirmişti. Ayrıca iki ülke sefiri, İstanbul'daki mevkidaşlarına Sultan ile ortak bir mülakatta bulunarak, eğer Sultan talepleri kabul etmezse hükümetlerinin bu türden zorlayıcı önlemlere başvuracaklarını ilan etmeyi gündeme getirmişti ${ }^{75}$.

Aslında bu tarihten neredeyse altı ay kadar önce, henüz malî delegeler konusu gündemde bile değilken, İngiltere'nin Selanik'e bir donanma göndererek Rumeli Vilayeti’nde ortak

73 Documents Diplomatiques Français (1871-1914), 2. Série (1901-1911), s. 73.

74 Further Correspondence Respecting the Affairs of South-eastern Europe, nr. 86-90, s. 58-59.

75 Further Correspondence Respecting the Affairs of South-eastern Europe, nr. 91, s. 59. 
bir idare mekanizması kurulmasını isteyeceği yönündeki bir ihbar üzerine II. Abdülhamid böyle bir teklifin gerçekleşmesine kesinlikle meydan verilmemesini Sadrazam Ferid Paşa'dan istemişti. “İngiltere Hükûmetinin bağteten Selanik’e donanma irsâli ve Rumeli vilâyât-1 şâhânesi için müşterek bir usûl-i idâre teklîfi yolunda bir teşebbüs ve hareket-i münferidede bulunması ahvâl-i hazıra-i siyâsiyenin ahenk-i umûmisine nazaran melhûz olmayıp" bu rivayetin uydurma olduğu cevabını veren Ferid Paşa yine de böyle bir teklifin meydana gelmemesi ve Osmanlı saltanatının hukukunu her şekilde muhafazası için elinden geleni yapacağını vurgulamıştır ${ }^{76}$. Bundan bir ay sonra Sultan II. Abdülhamid Sadrazam ve Hariciye Nazırını, Rumeli'de Osmanlı Devleti'nin uygulamaya karar verdiğinin ötesinde birtakım taleplerde bulunulmasına Avusturya ve Rusya'nın onay verdiği yönünde bir istihbarattan haberdar ediyordu. Bu iki devletin, daha önce kararlaştırılmış olanların ötesinde, birtakım tekliflerde bulunması görevlilerce gerekli savunmanın yapılmadığı ve ciddiyetin gösterilmediği anlamına gelecekti. Avusturya ve diğer devletlerin Osmanlı Devleti'nin hukuku ve menfaatlerine aykırı olarak ileri sürdükleri şeyler asla kabul edilemeyeceğinden, kendilerinden devlete olan sadakatlerinin gereği olarak vaktiyle ve layıkıyla müdafaada bulunmalarını, devlet ve memleketin zarar görmesine meydan bırakmamalarını istemişti ${ }^{77}$.

Ferid Paşa'nın Mart 1905'teki siyasî ortam içinde İngiltere'nin tek başına gerçekleştirmesini mümkün görmediği bir donanma operasyonu, Osmanlı makamlarının dikkatle takip ettikleri bir konuydu. Öte yandan İngiliz Dışişleri Bakanı Lansdowne Ağustos 1905 başında kendisine parlamentoda malî delegeler atanması teklifine dair bir soruya, büyük devletlerin bu konudaki taleplerini kabul ettirebilmek için gerekli tedbirlere kesinlikle başvurmak niyetinde oldukları cevabını vermişti ${ }^{78}$. Görüldüğü üzere Ağustos 1905 'te en azından İngiliz siyasî çevrelerinde tedbir içerikli çeşitli konuşmalar yapılmaya başlanmıştı. $\mathrm{Bu}$ ise aslında zorlayıcı diplomasinin erken işaretleri olarak değerlendirilebilir.

Bu arada İngiliz The Times gazetesi konu hakkında dikkat çekici bir haber yayınlamıştır. Buna göre, Makedonya'da kurulması düşünülen Avrupa malî kontrolüne dair tekliflerine bir kez daha Osmanlı hükümetinden ret cevabı alan Büyük Güçler, sadece taleplerini sürekli tekrar etmekle bir sonuç elde edemeyeceklerdi. Osmanlı hükümetine verilecek sonraki notada artık devletlerin zorlayıcı tedbirlere başvurma eğiliminde oldukları bildirilecekti. Alınacak önlemlerin mahiyeti hakkında ise ülkeler arasında görüşmeler yapılmaktaydı. Babıali'nin bu beklenmeyen inadı birtakım zorluklara sebep olmuştu ancak Avrupa uyumu bozulmamıştı, her bir devlet aynı tavrı takınıyordu. Sultanın danışmanları, Avusturya ve Rusya'nın bölgedeki ajan sivillerin yanında diğer devletlerce tayin edilecek maliye memurlarını görmek istemeyeceklerine inanıyorlardı ve gösterdikleri direnç bu inanca dayanıyordu. Bunun

76 BOA, Y.A.HUS, 484/138, Lef 1, 30 Zilhicce 1322 (7 Mart 1905).

77 BOA, Y.PRK.BŞK, 73/122. Yıldız Sarayı Başkitabet Dairesi'nden Sadarete, 13 Zilhicce 1322 (18 Nisan 1905).

78 BOA, Y.A.HUS, 492/43. Londra Sefareti'nden 11 Ağustos 1905 tarihinde Hariciye Nezareti'ne gelen telgraf. 
doğru olmadığına ikna edildikleri anda direnmekten vazgeçeceklerdi. Haberde Osmanlı hükümetinin bu inancından kısmen Avusturya ve Rusya devletlerinin sorumlu olduğu dile getiriliyordu. Adı geçen iki devletin bu tavrı İngiltere'de "Türkleri İngiliz sopasıyla dövmek" olarak niteleniyordu. Yani söz konusu iki devlet Türklere reformları kabul ettirmeye çalışırken; eğer ılımlı Avusturya-Rusya reform programını kabul etmezlerse İngiltere'nin kesinlikle daha sert bir teklif ile ortaya çıkacağını söylüyorlardı. Bunun sonucunda Babıali reformlar konusundaki tüm inisiyatifin İngiltere'den geldiğini, diğer devletlerin yarı gönüllü olduğunu düşünüyordu ${ }^{79}$.

Avusturya ve Rusya'nın haberde ifade edilen tutumunu arşiv belgelerinden de teyit etmek mümkündür ${ }^{80}$. Örneğin Sadrazam Ferid Paşa ile olan bir görüşmesinde Rusya Sefiri Zinovieff tam da Times gazetesinin yukarıdaki haberinde bahsedildiği gibi bir dil kullanmıştı. Avusturya ve Rusya hükümetlerinin sahip olduğu somut delillere göre Rumeli'deki üç vilayetin idare şekli hakkında İngiltere'nin bazı uygunsuz niyet ve tekliflerinin olduğu, bunların önüne geçilebilmek için Osmanlı Devleti'nin Rumeli'nin maliyesine ve asayişine dair sslahat programını hayata geçirmeye özen göstermesi gerektiğini söylemişti ${ }^{81}$. Diğer taraftan Rumeli'deki vilayetlere Avrupalı bir vali atanmasının İngiltere tarafından gündeme getirileceğine dair gazete haberleri ${ }^{82}$ Zinovieff'in İngiltere'ye dair yukarıda bahsedilen iddialarının gerçekliği konusunda Osmanlı hükümetinin kanaatini etkilemiş olmalıdır.

\section{Sefirlerin II. Abdülhamid ile Toplu Görüşme Girişiminde Bulunmaları}

Malî Komisyonun kabul edilmesi konusunda kararlı ve hemfikir olduklarını göstermek isteyen büyük devletler, İstanbul'daki sefirlerinin II. Abdülhamid ile toplu bir görüşme yapması için harekete geçmişlerdir. Avusturya ve Rusya sefïlerine göre Osmanlı sultanı malî delegelere dair talepler karşısında direniyordu çünkü devletler arasında Mürzsteg Programı konusunda tam bir ittifak sağlanamadığını görmüştü. İki ülke sefiri diğer devletlerden bu konuda yeterince yardım göremediklerinden yakınmıştır. Bu nedenle Sultana Büyük Güçlerin birlikte ve uyum içinde hareket ettiklerini ve niyetleri konusunda yanılgıya düştüguünü göstermek istiyorlardı. Hükümetlerinden aldıkları talimat sonrası, gerekli adımları atmak üzere harekete geçen Avusturya Sefiri Baron Heinrich von Calice ve Rusya Sefiri Ivan Zinovieff ortak bir nota hazırlamıştı.

79 The Times, 18 October 1905, s. 3.

80 BOA, Y.A.HUS, 482/54.

81 BOA, Y.A.HUS, 483/125. Sadrazam Ferid Paşa'dan Mabeyn'e, 15 Zilkade 1322 (31 Ocak 1905) tarihli tezkire.

82 The Times gazetesinde yer alan özellikle Balkan Komitesi’nin bu yönde İngiliz hükümetine yaptığı teklif ve baskılara dair haberler Osmanlı hariciyesi tarafından yakından takip ediliyordu. BOA, Y.A.HUS, 486/45, Lef 3. Londra Sefaretinden Hariciye Nezaretine gönderilen 1 Nisan 1905 tarihli telgraf. Bu düşünce birkaç seneden beri İngiliz basınında çıkan çeşitli haberlerde dile getirilmekteydi. Brooks, Managing Macedonia, s. 406, 432. 
19 Ekim 1905'te diğer Büyük Güçlerin İstanbul'daki temsilcileriyle paylaştıkları bu notaya göre iki ülke sefiri, Osmanlı hükümetinin yapılan tekliflere karşı direncinin kırılmasını sağlayacak önlemler konusunda diğer meslektaşlarıyla mutabakat sağlamayı amaçlamıştır. Babıali'nin tüm Büyük Güçlerin ittifak halinde olduğunu ve amaçlarına ulaşmak için zorlayıcı tedbirler almaktan çekinmeyeceklerini görene kadar direncini devam ettireceği varsayan Avusturya ve Rusya sefirleri bir modus procedendi önermişlerdir. Buna göre Hariciye Nezareti vasıtasıyla sultan ile toplu olarak görüşülecek, teklifleri kabul etmesi için zorlanacak, direnmeye devam edilirse Büyük Güçlerin şartların gerektirdiği önlemleri almak zorunda kalacağı ifade edilecekti. Eğer bu yöntem işe yaramazsa altı devletin sefirleri hükümetlerine başvurarak, zorlayıcı tedbirler konusunda ortak bir öneri sunacaklardı. İngiliz Sefiri O’Conor sultan ile görüşmenin toplu olarak değil de diplomatlar arasında en kıdemlisi tarafından yapılmasının doğru olacağına işaret etmiştir. Bununla birlikte, diğer devletler kabul ederse o da teklif olunan modus procedendiyi kabul edecekti. Bu arada Avusturya ve Rusya sefirlerinin tekliflerini duyan İtalya'nın İstanbul sefiri Guglielmo Imperiali, bu iki ülkenin Makedonya maliyesi konusunda inisiyatifi ellerine almalarına şaşırmıştı. Almanya'nın İstanbul' daki sefiri Baron Marschall von Bieberstein ise teklifi onaylamış ancak Makedonya'da malî kontrol kurulduktan sonra, adlî reformlardan konuşmaya başlamadan önce Osmanlı Sultanına itiraz etmesi için biraz süre tanınması gerektiğini söylemiştir. Avusturya Sefiri Baron Calice, Almanya sefirinin desteğinden emindi ancak bir bahriye nümayişi gerekli görülürse, sefaretlerin yürüttüğü sürece şimdiki gibi bağlı kalmayarak, bu nümayişe katılmayacağına inanıyordu ${ }^{83}$.

Dışişleri Bakanı Lansdowne, 20 Ekim'de O’Conor'a gönderdiği telgrafta, o sabah görüştüğü Avusturya-Macaristan sefiri Mensdorff'un Sultan ile toplu bir mülakatta bulunulması teklifini kendisine de ilettiğini haber veriyordu. Avusturya ve Rusya bu mülakattan istenilen sonucun elde edilmemesi durumunda atılacak adımları tartışmaktaydılar. O'Conor'un da alınacak herhangi bir tedbire katılmaya yetkili olacağını söyleyen Lansdowne, Babıali'nin Maliye Komisyonu hakkındaki olumsuz tavrını devam ettirmesi durumunda Büyük Güçlerin taleplerinin infazı yoluna gitmekten geri durmayacaklarını belirgin bir biçimde ortaya koymaları için sefirlere talimat verilmesi fikrindeydi. Bunu ifade ederek Mansdorff' $u$ cesaretlendirmişti ${ }^{84}$.

İngiliz Dışişleri Bakanı Lansdowne, bir taraftan Makedonya'da asayiş ve güvenliğin sağlanması için ihtiyaç duyulan reformların hayata geçirilebilmesinin önünde adeta bir engel gibi gösterilen malî denetim meselesinin Babıali’ye kabul ettirilmesinde, gerekirse kuvvet kullanılmasına yönelik olarak ciddi bir çaba içindeyken, diğer taraftan Makedonya sorununa

83 Documents Diplomatiques Français (1871-1914), 2. Série (1901-1911), s. 87-89. İstanbul'daki Fransa Maslahatgüzarı Boppe’tan Dışişleri Bakanı Rouvier'e, 20 Ekim 1905.

84 Further Correspondence Respecting the Affairs of South-eastern Europe, nr. 92, s. 60. 
yönelik sahip oldukları özel ilgiyi büyük devletlerin her zaman kabule hazır oldukları şeklindeki değerlendirmeleriyle Avusturya ve Rusya’yı teşvik ediyordu.

Osmanlı Devleti, artık Üsküp’te toplanmış bulunan Maliye Komisyonu'nu tanıması için diplomatik bir kıskaca alınmıştı. İstanbul'daki Avusturya ve Rusya sefirleri meslektaşlarını II. Abdülhamid ile toplu bir mülakatta bulunma fikrine ikna etmekte büyük ölçüde başarılı olmuşlardı. İki müttefik, büyük devletlerin bir ret cevabına hazır olması ve bir çeşit zorlayıcı yöntemleri içeren plan ile beklemeleri gerektiğini düşünüyordu. Onlara göre en etkili adım Türk kıyılarına yönelik bir donanma gösterisi yapılması olacaktı. Bu tür bir gösteri için gerekli hazırlıklar konusunda sefirler tarafından ön çalışılma yapılmasını teklif etmişlerdir. İngiltere Dışişleri Bakanı Lansdowne Londra'daki Rus sefirine, beklendiği gibi İngiliz Hükümetinin Büyük Güçlerle ortak hareket edeceğini ve Sir O'Conor'a da gerekli talimatların verileceğini söylemişti ${ }^{85}$. Anlaşılacağı üzere Makedonya'ya gönderilen uluslararası Maliye Komisyonu'nu tanıması için Osmanlı Devleti'ne fiili bir müdahalede bulunulması konusunda inisiyatif artık büyük devletlerin İstanbul'da bulunan sefirlerine birakılıyordu.

Sefirler, II. Abdülhamid ile toplu bir görüşmede bulunma taleplerini resmen Osmanlı Devleti'ne iletmeden önce, taleplerinin reddedilmesi ihtimalini de değerlendirmişlerdi. Yapılan toplantıda Avusturya ve Rusya sefirleri padişahın direnmeye devam etmesi karşısında meslektaşlarına bir bahriye nümayişi yapılmasını açıkça ortaya attılar. Onlar da acil koduyla bu tekliften kendi dışişlerini haberdar ederek, görüş sordular. Bahriye nümayişi konusundaki teklifin kabul edilmesi ilk etapta iki sonuç doğuracaktı. Birincisi Büyük Güçler artık sefirlerini Osmanlı Devleti'ne karşı kullanacakları dil konusunda serbest bırakacaklar, ikincisi ise olası bir donanma gösterisinin detaylarının belirlenmesi için harekete geçilecekti. O sırada Madrid'de bulunan Fransa Dışişleri Bakanı Rouvier 24 Ekim tarihinde, İngiltere katılırsa Fransa'nın böyle bir nümayişte yer almasına onay verdi ${ }^{86}$.

Londra'daki Avusturya ve Rusya sefirleri bahriye nümayişi konusunda İngiltere hükümetinin görüşünü öğrenmek için harekete geçmişlerdi. Fransa'nın Londra sefiri Paul Cambon burada önemli bir noktanın altını çizmişti. Buna göre esasında Avusturya ve Rusya hükümetleri daha önce İngiltere Dışişleri Bakanı Lord Lansdowne'un gündeme getirdiği bir öneriyi yenilemekteydiler. Cambon, Lansdowne'un bu önerisinden Rouvier'i daha 18 Ekim'de haberdar etmişti. Dolayısıyla İngiliz hariciyesi aslında daha önce kendisinin gündeme getirdiği bir teklifi kabul ediyor, her türlü nümayişe katılacağı cevabını veriyordu. Fransız diplomatik yazışmalarında Avusturya ve Rusya’yı Osmanlı Devleti'ne baskı uygulamak konusunda sıkıştıranın Lord Lansdowne olduğu açıkça belirtilmişti. Bu baskı, Rusya’nın Karadeniz’de müstakil bir hareketinin önüne geçmek için sadece tek bir noktada,

85 Lansdowne'dan Sir C. Hardinge'e, 23 Ekim 1905; Further Correspondence Respecting the Affairs of Southeastern Europe, nr. 98, s. 68.

86 Documents Diplomatiques Français (1871-1914), 2. Série (1901-1911), s. 103. 
Midilli'de icra edilecekti. O’Conor'a 24 Ekim'de gönderdiği bir telgrafta Lansdowne ayrıca Limni’nin de işgal edilebileceğini bildirdi ${ }^{87}$.

Gerçekten de Avusturya sefiri Calice olası bir bahriye nümayişine İngiltere'nin öncülük etmesinden ve planın genel hatlarını belirlemesinden endişe etmekteydi. Zira en başından beri Avusturya ve müttefiki Rusya Makedonya konusunda uzun süredir sahip oldukları ayrıcalığı kaybetmek istemiyorlardı. Bu nedenle Baron Calice Gołuchowski'den bahriye nümayişi konusunda hızlı davranarak, İngiltere'nin önünü kesmesini istedi ${ }^{88}$.

Sultan II. Abdülhamid ise Üsküp'e kadar gitmiş olan maliye memurlarının hangi yollarla ülkelerine iade edilebileceklerinin üzerinde düşünülmesi için Meclis-i Vükela’ya talimat vermiştir. Bu konuda uygun bir yöntem göstermeleri konusunda büyük devletlerin İstanbul'daki sefirlerine başvurulması gündeme gelmişti. Bununla birlikte sefirler bu aşamada memurların görev süreleri ve içeriklerini müzakere etmeye kalkarlarsa bu kesin bir dille reddedilecek, görüşmeler yalnızca söz konusu maliye memurlarının ülkelerine iadelerinin bir yolunu bulmaya münhasır kılınacaktı. Sefirlere herhangi bir müracaatları olmadan cevap verilmesinin devleti zayıf göstereceği ve tekliflerinde 1srar etmelerine neden olacağı gerekçesiyle Meclis-i Vükela bu yola başvurulmamasını önermiştir. Zaten memuriyetleri tasdik olunmadığı sürece orada kalmalarının kendilerine bir faydası olmayacağını anlayacaklardı. Dolayısıyla Sultan II. Abdülhamid ve Osmanlı hükümeti zoraki bir şekilde Üsküp'e gönderilmiş olan yabancı maliye memurlarının tanınmamaları ve reddedilmeleri konusunda bir kez daha kesin tavır göstermişti ${ }^{89}$.

Osmanlı Devleti bu tarihte artık, ret cevabında ısrar etmesi karşısında sefirlerin alınacağını söyledikleri tedbirlerin içeriği hakkında bilgi toplamaya başlanmıştır. Nitekim yurt dışındaki Osmanlı diplomatları görev bölgelerinde konu hakkında çıkan haberleri tüm detayıyla Hariciye Nezareti'ne iletiyorlardı. Peşte Başşehbenderinin Ekim sonunda gönderdiği, Osmanlı Devleti suçlandığı bir gazete haberinde, reformların yeterince uygulanmadığı ileri sürülüyordu. Büyük devletlerin taleplerinin kabul edilmesi için İzmir ve Selanik limanlarına gerektiği durumda birkaç gemi göndermelerinin yeterli olacağından bahsediliyordu ${ }^{90}$.

Osmanlı Devleti'nin Makedonya'daki reformların hayata geçmesini istemediği ve bu nedenle başarısız olunduğu yönündeki bu tavır aslında yeni değildi. Bir yıl öncesinden, yani 1904 yılı yazından itibaren Avrupa basınında benzer haberler yayınlanmaktaydı. Osmanlı hariciyesine göre Bulgar kaynaklarına dayanan bu tür haberlerin maksadı, Osmanlı hükümetinin Rumeli vilayetindeki çalışmaları hakkında şüphe oluşturmaktı. Islahat programını başarısız

87 Cambon'dan Rouvier'e, 25 Ekim 1905: Documents Diplomatiques Français (1871-1914), 2. Série (19011911), s. 115-116.

88 Steven W. Sowards, Austria's Policy of Macedonian Reform, s. 61.

89 BOA, YEE, 50/74, Lef 2. 1 Ramazan 1323 (30 Ekim 1905) tarihli Sadaret tezkiresi; BOA, Y.A.RES, 133/47.

90 BOA, Y.A.HUS, 495/45, Lef 3. 
kılmak amacıyla Osmanlı Devleti'nin, Müslüman eşkıyadan oluşan çeteler kurduğu dahi iddia olunmaktaydı. İddiaları Hariciye Nezareti'ne ileten Viyana Sefareti zaten Osmanlı Devleti'ne pek teveccüh göstermeyen ${ }^{91}$ bu alg1 operasyonu karşısında Avrupa kamuoyunu doğru bilgilendirmek için karşı haberler ve açıklamalar yayımlatmaktaydı. Diğer taraftan İngiliz gazetelerinde çıkan benzer haberlerde Avusturya ve Rusya'nın gerçek manada bir ıslahat istemediklerinden, sadece zaman kazanmaya çalıştıklarından, durumun hiç de iç açıcı olmadığından Rumeli'de 1905 yılı baharında büyük bir ayaklanma çıkacağından bahsedilmekteydi' ${ }^{92}$. Bölgede yeni bir ayaklanma çıkacağına dair iddiaların İngilizlerin öncülük ettiği malî kontrol fikrini desteklemek için başvurulan bir argüman olduğu anlaşılmaktadır.

Diğer taraftan Lord Lansdowne, Londra'da Almanya sefiri Kont Metternich ile görüşerek Maliye Komisyonu meselesinde Alman Hükümeti'nin tutumunu anlamaya çalışmıştır. Görüşmede Almanya'nın Sultan ile ortak mülakat konusunda Rus-Avusturya teklifini kabul ederek İstanbul'daki sefirine de bu yönde talimat verdiği, ancak bir donanma gösterisi yoluyla Babıali'nin Büyük Güçlerin taleplerini kabule zorlanmasının gerekliliği noktasında şu an için bir sonuca ulaşamadığg ortaya çıkmışt $1^{93}$.

Osmanlı Devleti’nin itirazlarına rağmen yabancı maliye memurları Üsküp'e gitmiş, orada Avusturya ve Rusya devleti adına çalışmakta olan ajan sivillerle toplantılar yaparak, bölgenin malî meseleleri üzerinde çalışmaya başlamıştır. Aralarından Rus ajan sivil Demeric'i başkan seçen heyet bir taraftan da kendileri için bir nizamname (reglement) hazırlamaya başlamıştır ${ }^{94}$. Bunun üzerine Osmanlı hariciyesi altı büyük devletin sefirlerini temsil eden AvusturyaMacaristan sefiri Baron Calice'e 20 Ekim'de verdiği yeni bir nota ile durumu protesto etmiştir $^{95}$. Notada devletin tanımadığı yabancı birtakım kimselerin iç işlerine karışmasının

91 "Gerçi butlanı vehle-i ulâda göze çarpmakta ise de telmîhât-ı mezkûrenin tekrar edile edile zaten bize pek de müteveccih olmayan efkâr-l umûmiyeyi taglît edebileceği derkârdır." Viyana Sefareti'nden Hariciye Nezaretine 19 Temmuz 1904 tarihli tahrirat: BOA, Y.A.HUS, 476/99, Lef 3. Bilhassa Rumeli'de genel bir müfettişlik kurmasından sonra Avrupa ve özellikle İngiltere basınında Osmanlı Devleti aleyhindeki olumsuz yayınlar ve buna karşı verilen mücadele için bkz. Zeynep İskifyeli - Özgür Tilbe, "Makedonya Meselesinde Osmanlı Devleti'nin Dış Basındaki Sesi: Rumeli Umumî Müfettişi Hüseyin Hilmi Paşa”, Çeşm-i Cihan: Tarih Kültür ve Sanat Araştırmaları E-Dergisi, IV/2 (2017), s. 27-48.

9230 Eylül 1904 tarihli Morning Post Gazetesi'nde yayınlanan bu haberin kaynağı gazetenin İtalya muhabirinin gönderdiği bir telgraftı. Osmanlı makamları bu tür haberleri dikkatli ve detaylı bir analize tâbi tutuyordu. Nitekim bahis konusu haberde özellikle İngiltere'nin Rumeli meselesinde Avusturya ve Rusya'nın toprak elde etmek veya aşırı teklif ve müdahaleleri karşısında İtalya ile birlikte hareket edeceğine dair ifadelerin, ilgili muhabirin İtalyan resmi çevreleriyle olan yakın ilişkisi düşünülerek dikkate alınması gerektiğine işaret olunmuştur. BOA, Y.A.HUS, 480/93, Lef 2.

93 Lansdowne'dan Sir F. Lascelles'a, 24 Ekim 1905; Further Correspondence Respecting the Affairs of Southeastern Europe, nr. 100, s. 68-69.

94 The Times, 18 October 1905, s. 3.

95 İkinci Katip İzzet Paşa günlüklerinde protesto kararının alınmasında Sadrazam Ferid Paşa'nın tereddüt gösterdiğini, kendisinin kararlı duruşta devam edilmesi gerektiğini söylemesi üzerine II. Abdülhamid'in protesto emir verdiğini yazmaktadır: Abdülhamid'in Kara Kutusu Arap İzzet Holo Paşa 'nın Günlükleri, I, Eski yazıdan aktaran ve yayına hazırlayan İbrahim Küreli, İş Bankası Kültür Yayınları, İstanbul 2019, s. 420. 
kabul edilmediği bir kez daha vurgulanmıştır. Bunun mevcut anlaşmalara aykırı ve saldırı olduğu, devletin çıkarlarına ve hukukuna uymadığı vurgulanarak, adaletin ruhuna uygun bir şekilde konuya son vermeleri büyük devlet sefirlerinden bir kez daha rica olunmuştur ${ }^{96}$.

Atılacak diplomatik adımları kendi aralarında planlayan büyük devletlerin İstanbul'daki temsilcileri malî kontrol meselesini, doğrudan II. Abdülhamid'e iletmek için harekete geçmişlerdir. Rusya Dışişleri Bakanı kendisiyle görüşen St. Petersburg'daki Fransa maslahatgüzarına, tamamen yeni olan bu yönteme bir itirazının olmadığını, ancak Sultan yine ret cevabı verirse derhal bir silahlı bahriye nümayişinde bulunulması gerektiğini ifade etmiştir. Görüşmede Rusya Dışişleri Bakanı dikkat çekici bir notu da paylaşmıştı. Kendisine gelen bilgilere göre bahriye nümayişi konusundan pek hoşlanmayan Almanya, Sultan üzerinde etkili bir baskı uygulamaktaydı, bu şartlar altında herkesin beklentisinin aksine yakında tatmin edici bir çözüm olabilirdi ${ }^{97}$. Paris basınında çıkan Londra kaynaklı bazı haberler de bahriye nümayişi seçeneğinden önce Almanya'nın Osmanlı hükümeti üzerindeki etkisini kullanmak için son bir teşebbüste bulunacağına işaret ediyordu ${ }^{98}$. Osmanlı Devleti'ne karşı bahriye nümayişi uygulanması ihtimali güçlendikçe, Almanya'nın İstanbul sefiri Bieberstein II. Abdülhamid'i büyük devletlerin taleplerini kabule ikna etmek için gösterdiği çabayı ciddi şekilde artırıyordu. Bieberstein'ın bu tavrı II. Abdülhamid'in bu dönemde en yakınında bulunanlardan İzzet Paşa'yı hayal kırıklığına uğratmış, hatta zaman zaman kızdırmıştır99.

Nihayet altı büyük devletin İstanbul'daki sefirleri 26 Ekim'de Hariciye Nezareti'ne bir nota vererek Rumeli'deki üç vilayetin malî işlerine dair birtakım konuları iletmek üzere ertesi cuma günü selamlık resminden sonra II. Abdülhamid ile toplu bir görüşme istemişlerdir ${ }^{100}$. Osmanlı Devleti daha önce hiçbir örneği bulunmayan sefirlerin bu toplu görüşme talebine çok hızlı bir şekilde olumsuz cevap vermiştir. II. Abdülhamid, daha ciddi birtakım adımlar atılarak böyle bir görüşmeye gelmelerinin gereksiz olduğuna sefirlerin bizzat kanaat getirmelerinin sağlanmasını istemiştir ${ }^{101}$.

\section{Osmanlı Devleti’nin Sefirlerin Toplu Görüşme Talebini Reddetmesi}

Osmanlı hariciyesi büyük devlet sefirlerinin taleplerini yenilemelerinin veya telgraf yoluyla sultana ulaşmalarının önüne geçmek için Hariciye Nezareti Tahrirat Katibi Nuri Bey vasitasıyla, bu isteğin uygunsuzluğunu şifahen de bildirmiştir. Burada altı çizilen hususlar,

96 Documents Diplomatiques Français (1871-1914), 2. Série (1901-1911), s. 99-100. İstanbul'daki Fransa Maslahatgüzarı Boppe’tan Dışişleri Bakanı Rouvier'e, 21 Ekim 1905; O’Conor'dan Lansdowne'a; Further Correspondence Respecting the Affairs of South-eastern Europe, nr. 105, s. 71.

97 Documents Diplomatiques Français (1871-1914), 2. Série (1901-1911), s. 118.

98 BOA, YEE, 50/73, Lef 1. Paris Sefareti Maslahatgüzarından Hariciye Nezaretine gönderilen 26 Ekim 1905 tarihli telgrafin tercümesi.

99 Arap İzzet Holo Paşa'nın Günlükleri, I, s. 417.

100 Kırmızı, Avlonyalı Ferid Paşa, s. 262.

101 BOA, YEE, 49/87. 
padişah ile tek tek görüşmenin her zaman mümkün olduğu, Rumeli' deki vilayetlerin maliyesine dair kararların Babıali tarafından alındığı, dolayısıyla bu konuların Babıali ile görüşülmesi gerektiği, bu nedenle Hariciye Nezareti'nin kendisine iletilen toplu görüşme talebini padişaha arzının mümkün olmayacağıydı. Avusturya Sefïri Baron Calice ise verdiği cevapta sürekli reddedilmekte olan tekliflerinin Babıali tarafından kabul edilmesi gerektiğini ifade etmek üzere padişahla görüşmek istediklerini, Osmanlı hükümetinin bu işten kaçınmasının birtakım elim neticeler doğuracağını, bu bakımdan büyük devletlerin sefirleri aracılığıyla konuya padişahın dikkatini çekmekte kendilerini serbest gördüklerini belirtmiştir ${ }^{102}$.

Hariciye Nazırı Tevfik Paşa sefirlere bir yandan diplomatik kaideler ve nezaket kurallarını hatırlatırken, diğer taraftan konunun bir iç mesele, devletin içişlerine ait bir husus olduğunu, bu nedenle de sadece Babıali ile görüşülebileceğini ifade etmiştir. Osmanlı hükümeti içişlerini ilgilendiren bir konuda malî delegeler tayinini, ülke idaresine bir müdahale olarak gördüğü için, bir kez daha reddetmiştir. Osmanlı Devleti’nin hızlı cevabı ve kullandığı terminolojinin açıklığı karşısında yaşadığı şaşkınlığı gizleyemeyen İstanbul'daki Fransız maslahatgüzarı Boppe'a bakılırsa az da olsa II. Abdülhamid'in bir toplu mülakat talebini kabul edeceğini ve direnmekten vazgeçeceğini düşünen sefirler vard1 ${ }^{103}$.

Bu cevap ile aynı zamanda konu özelinde Babıli ve Meclis-i Vükela yani Osmanlı hükümeti ile II. Abdülhamid'in rolleri bilinçli bir şekilde ayrıştırılmış, bütün sorumluluğun Babıali'de olduğuna dair güçlü bir vurgu yapılmıştır. Böylece mutlak hükümran olarak Osmanlı padişahının iradesinin ve kararlarının sorgulamaya açılmasının önüne geçilmeye çalışılmıştır.

Osmanlı Hariciyesi büyük devletlere, Rumeli' de uygulanan reform programına ve bunların dayanağı olan anlaşmalara sadık olduğunu bir kez daha hatırlatıyor, yükümlülüklerini yerine getirmekte olduğunu, planlananın dışında hiçbir talebi meşru kabul etmeyeceğini, zira bunun herkes tarafından arzulanan çözümü engelleyeceğini bildiriyordu ${ }^{104}$.

Rumeli'nin malî işlerine müdahale hakkı elde etmeye yönelik haksız fikir ve maksatlarını kabul ettirmek için büyük devletlerin bazı "vesâil-i tehdîdiyeye" teşebbüs etmelerini bu aşamada muhtemel gören Osmanlı devlet adamları, alınan kararın arkasında durmaktan başka yapacak bir şey olmadığına inanarak, bundan sonra bütün stratejilerini kararın savunulması üzerine kurmuşlardır ${ }^{105}$.

102 BOA, YEE, 50/73, Lef 4. Hariciye Nezareti'nden Mabeyn Başkitabetine 27 Şaban 1323 (27 Ekim 1905) tarihli hususi tezkire.

103 Boppe’tan Rouvier'e, 27 Ekim 1905, Documents Diplomatiques Français (1871-1914), 2. Série (1901-1911), s. $120-122$.

104 O'Conor'dan Lansdowne'a; Further Correspondence Respecting the Affairs of South-eastern Europe, nr. 107, s. $72-73$.

105 Sadrazam ve Hariciye Nazırının ortak arizaları: BOA, YEE, 50/73, Lef 2; Kırmızı, Avlonyalı Ferid Paşa, s. 262. 
Avusturya sefiri Baron Calice diğer meslektaşları adına verdiği, yukarıda bahsedilen karşı cevabında konunun tamamen Babıli'nin sorumluluğunda bulunduğunu kabul ettiklerini, bununla birlikte padişah ile görüşmek istemelerinin, halihazırda reddedilen tekliflerinin kabulünün fazlasıyla gerektiğini Babıali’ye göstermeye yönelik olduğunu söylüyordu. Baron Calice, verilen ret cevabının padişahın hükümetine yönelik acı sonuçlar doğuracağını söyleyerek tehditlerini bir kez daha yeniliyordu. Bu arada Rus sefir Zinovieff, aynı gün Dışişleri Bakanı Lamsdorf'a padişahı ikna etmek için yalnızca bir bahriye nümayişinin yeterli olmayacağını, daha ciddi önlemlerin alınması gerektiğini iletmişti ${ }^{106}$.

$\mathrm{Bu}$ karardan birkaç gün sonra II. Abdülhamid konunun Encümen-i Vükela'da görüşülmesini istemiştir. Büyük devletlerce birbiri ardına yapılan tekliflerinin reddedilmesi karşısında sefirlerin tehditvârî beyanlarını dikkate alan padişah, devletlerin atabileceği adımların müzakere edilmesini istemiştir. Meclis-i Mahsus, Hariciye Nezareti'nin konu hakkında yaptığı değerlendirmelerden hareketle sefirlerin ne gibi tedbirlere başvurabileceğine dair çıkarımlarda bulunmuştur. Buna göre büyük devletler arasında bir ortak kararın varlığ hissedilemiyordu. Dolayısıyla gösterecekleri hareket tarzının içeriği ve şeklinin şimdiden bilinmesi mümkün değildi. Yapmak istedikleri şey üç vilayetin maliyesine müdahale etmek olup, bu durum gelecekte ciddi sonuçlar doğurabilirdi. Bu nedenle devletin tavrı mutlaka muhafaza edilmeli, kararlı duruştan vazgeçilmemeliydi. Bunun haricinde görüşmelerde büyük devlet sefirlerinin onurlarını kırmadan, söz konusu maliye memurlarının geldikleri ülkelere iadesini sağlanmak üzere İstanbul'a davet edilerek, Hariciye Nezareti tarafindan üç vilayetin gelir-gider bilançosunun kendilerine gösterilmesi fikri gündeme gelmiş ${ }^{107}$; ancak bunu memuriyetlerinin tasdiki şeklinde değerlendirerek müzakereye girişebilecekleri düşünülmüştü. Sonuç itibariyle, devletin mahallî malî işleri idare etme konusundaki hareket serbestisinin hiçbir vakit kısıtlanamayacağına dayanılarak, önce Hariciye Nazırı tarafından sefirlerin bir ikisinin kazanılması, böylece gerçekleşmekte olan bir ortak hareketin etkilerinin sınırlandırılmasına çalışılması, bu mümkün olmazsa Osmanlı hükümetinin aldığı kararın muhafazasında sebat edilerek bahsi geçen maliye memurlarının iadelerine yönelik uygun bir tedbir gösterilmesinin sefirlere tebliğ olunmasında, ikinci olarak Osmanlı devletine karşı alınacağını sefirlerin beyan ettikleri tedbirlerin içeriği hakkında çeşitli yollarla bilgi edinilmesinde karar kılınmışt ${ }^{108}$. Bu değerlendirme ve kararların dayanağı yukarıda bahsedilen yabancı siyasetçinin mütalaasındakilerle örtüşmektedir. Devletler arasında konuya dair tam bir uyum bulunmadığı, malî kontrol taleplerinin uzun vadede çok ciddi sonuçlarının görüleceği, bu nedenle devletin kararlı duruşunun sürdürülmesi, eğer bir baskı veya müdahale söz konusu olacaksa bunun etkilerinin sınırlandırılmasına çalışılması değerlendirilmiştir.

106 Documents Diplomatiques Français (1871-1914), 2. Série (1901-1911), s. 121.

107 Bu arada maliye delegelerine nişan verilmesi de düşünülmüştür: Arap İzzet Holo Paşa'nın Günlükleri, I, s. 424.

108 BOA, YEE, 49/27. 29 Şaban 1323 (29 Ekim 1905) tarihli Encümen-i Mahsus mazbatas1. 


\section{Osmanlı Devleti Üzerindeki Diplomatik Baskıların En Üst Seviyeye Çıkarılması}

Kasım ayı başlarında Avrupa'daki çeşitli gazetelerde artık Osmanlı Devleti'ne yönelik bir bahrî nümayiş yapılacağına dair açık haberler çıkmaya başlamıştı. Peşte'de yayınlanan Lloyd Gazetesi büyük devletlerin konu hakkında bir anlaşmaya vardıklarını, sadece Osmanlı Devleti'ne verdiği kararın sonuçlarını düşünmek için zaman tanımak amacıyla müzakereleri uzattıklarını bildiriyordu ${ }^{109}$. Haberin detaylarında Avrupa kamuoyunu bahriye nümayişine hazırlamaya yönelik ifadelerin izleri belirgin olarak görülmektedir. Malî komisyon uygulamasının padişahın hükümranlık hakkına hiçbir şekilde zarar vermeyeceği ifade edilmişti. Bunun Osmanlı padişahının vakar, haysiyet ve menfaatini ihlal edecek tazyik tedbirlerine tercih edilmesi gerektiği, durumu incelemek ve tartmak için Osmanlı padişahına zaman tanındığı, o nedenle üzerinde ittifak sağlanmasına rağmen bahriye nümayişinin şu anda hayata geçirilmediği haberde detaylıca anlatılmıştı. Bahriye nümayişinin gidebileceği son nokta ve bazı radikal önerilere de yer verilen haberin aşağıdaki bölümü dikkate alınırsa, Osmanlı yönetimini korkutarak, tedirgin etmeyi amaçladığı açıktır.

"Hadd-i zatında bir nümâyiş-i bahrî hangi devlete karşı icrâ olunursa o devlet için oldukça vahim bir şeydir zira nümâyişten matlûb olan maksat istihsâl edilemediği takdîrde bu tedbîr nâ-kabil-i tayîn ve tahmîn netâyîc tevlîd edebilir. Şimdiden İzmir gümrüğ̈̈nün veyahut arazi-i Devlet-i Aliyye'den daha mühim bir parçasının zabtından bahsolunuyor. Dersaadet'te bulunan ecnebi sefirlerden bazlları nümayiş-i bahrî yerine daha müessir bir tazyîk icrâ etmiş olmak için düvel-i muazzamanın jandarma tensikâtındaki devâir-i aidelerine göre vilâyat-ı selâse nevâhisini işgal ve idâre etmeleri icâb edeceği fikrinde bulunuyorlar."

Yukarıdaki ifadelerde verilen mesaj, eğer büyük devletler yapılacak bahriye nümayişinden istediklerini elde edemezlerse meselenin sonuçları tahmin edilemeyecek bir şekilde gelişebileceği, İzmir gümrüğü veya başka bir Osmanlı toprağının işgal olunabileceğiydi. Haberin sonunda, bu süreçte sıkça gündeme getirilen bir hususa bir kez daha atıf yapılmıştır. Eğer Makedonya’ya dair bir 1slahat yapılmazsa Bulgarlar ayaklanacaklar, bunun üzerine böyle bir isyanı bastırmakta çok zorlanacak olan Osmanlı Devleti şimdi kendi rızasıyla kabul etmediği birtakım uygulamaları o zaman zorla ve ağır bir bedel ödedikten sonra kabul etmek zorunda kalacakt1 ${ }^{110}$.

Toplu görüşme taleplerine olumsuz cevap almaları üzerine hükümetlerinin bilgisi dahilinde Rusya sefiri Zinovieff ve Avusturya-Macaristan sefiri Baron Calice, atılacak adımlar konusunda birkaç gün birlikte çalışarak, bazı öneriler kaleme almışlardır. Bu noktada

109 BOA, Y.A.HUS, 495/58, Lef 2. Hariciye Nazırı Tevfik Paşa’nın Sadarete gönderdiği 11 Şaban 1323 (9 Kasım 1905) tarihli tezkire.

110 BOA, Y.A.HUS, 495/58, Lef 3. Peşte Şehbenderinin takriri ve ekinde 3 Kasım 1905 tarihli Peşte Lloyd Gazetesi'ndeki haberin tercümesi. 
gündeme yeni talepler de gelmiştir. Bu şekilde daha sonra Osmanlı Devleti ile sorun olacağ 1 düşünülen konu başlıklarının tek bir paket şeklinde kabul ettirilmesi, zorlayıcı diplomasinin bir enstrümanı olarak uygulanacak bahriye nümayişinin amacını oluşturacaktı.

İki ülke sefirinin Petersburg ve Viyana'daki hükümetlerine sundukları söz konusu kararlara göre yapılacak bahriye nümayişi etkili olmak zorundaydı. Dolayısıyla büyük devletlerden her biri bir savaş gemi göndermeliydi. Gemiler Anadolu veya Avrupa kıyılarına gönderilmeyecekti; zira bu bir isyanı ya da fanatik bazı davranışları tetikleyebilirdi. Bunun yerine Ege'de bir veya birkaç ada hedef alınacaktı. Limni, Rodos ve Midilli adaları ismen zikredilmişti. Nümayişi icra edecek kumandanlara verilen talimatta gümrüklerin ele geçirilmesi ve telgrafhanelerin işgaline izin verilirken, ticaretin güvenli bir şekilde devam etmesinin sağlanması istenmişti. Babıali’ den sadece malî kontrolü kabul etmesi değil, Rumeli umumi müfettişi, ajan siviller ve sözleşmeli jandarma zabitlerinin görev sürelerini uzatması da istenilecekti ${ }^{111}$. Bu öneriler kısa bir süre sonra Rus ve Avusturya hükümetleri tarafindan diğer büyük devletlere sunulmuştur.

Ekim 1905 sonları itibariyle artık Osmanlı Devleti’nin Akdeniz'deki adalarına yönelik bir bahriye nümayişi önemli bir gündem maddesiydi. Yapılacak bir donanma gösterisinin içeriği de hızlıca şekilleniyordu. Rus ve Avusturya sefirleri hükümetlerine donanma gösterisine katılacak gemilerin önce Pire'de buluşmasını, iki gün kaldıktan sonra Midilli’ye hareket etmesini teklif etmişlerdi. Midilli Adası işgal edilebilir, eğer istenilen sonuç elde edilemezse gemiler daha sonra İmroz ve Limni adalarına gönderilebilirdi ${ }^{112}$. İngiltere Dışişleri Bakanı Lansdowne, "Büyük Güçler zorlayıcı tedbirler almaya sürüklenmeleri durumunda taleplerini yeniden düşünmelidirler. $\mathrm{Bu}$ yapılmadan Babıali bundan sonra ortaya çıkması muhtemel herhangi bir zorluk durumunda, son dakikaya kadar engellemede bulunmakta israr etme cesareti gösterecektir” diyerek O'Conor'dan bu görüşü mevkidaşlarına benimsetmesini istemekteydi. İngiltere için önemli olan Maliye Komisyonunun görev ve çalışma usullerinin düzenlendiği Nizamnamenin (Reglement) ve Büyük Güçlerin adlî yönetime nezaret etmesinin kabul ettirilmesiydi ${ }^{113}$.

Yapılacak bahriye nümayişine Büyük Güçlerin tamamının katılması çok önemli görülüyordu. Rus ve Avusturya sefirleri yine de bir “ortak girişim” mümkün olmazsa alternatif bir plan hazırlamışlardı. Detayları hakkında bilgi verilmeyen bu alternatif plan önerisine Paris ve Londra prensipte onay vermişlerdi ${ }^{114}$.

111 Documents Diplomatiques Français (1871-1914), 2. Série (1901-1911), s. 122.

112 O’Conor'dan Lansdowne'a, 2 Kasim 1905: Further Correspondence Respecting the Affairs of South-eastern Europe, nr. 109, s. 73-74.

113 Further Correspondence Respecting the Affairs of South-eastern Europe, nr. 110, s. 74.

114 Rouvier'den İstanbul ve Petersburg'daki Fransa elçiliklerine, 28 Ekim 1905: Documents Diplomatiques Français (1871-1914), 2. Série (1901-1911), s. 127. 
Üzerindeki baskı giderek artan Osmanlı Devleti, diplomatik temsilcileri aracılığı ile büyük devletlerin tekil olarak pozisyonlarını öğrenmeye çalışıyordu. Kasım başında Fransa'daki Osmanlı maslahatgüzarlığı güvenilir bir kaynaktan aldığı bazı bilgileri paylaşmıştı. Buna göre Fransa kabinesi maliye delegeleri meselesi gündeme ilk geldiğinde bu fikre sıcak bakmayarak, Osmanlı Devleti'nin bölgenin malî işlerine yönelik hazırlamış olduğu nizamnamenin uygulanmasının, devletten birtakım teminat alınması şartıyla yeterli olacağı kanaatindeydi. Diğer büyük devletlere bildirdiğinde öncelikle İtalya ve İngiltere, Fransa'nın bu mütalaasına katılmamış, maliye delegelerinin tayin edilmesi gerektiğinde ısrar etmişlerdir. $\mathrm{Bu}$ arada Almanya'nın oluşturulan ekibe bir delege göndermesi üzerine yalnız kalmak istemeyen Fransa da bu yolu takibe mecbur kalmıştır. Konuyu gündemin en önemli maddesine getiren Osmanlı maslahatgüzarı, Osmanlı hükümeti tayin olunan maliye delegelerini tanımamakta direnirse bir bahriye nümayişi yapılacağına dair bazı rivayetler dolanıyorsa da henüz Fransa kabinesine böyle bir teklif getirilmediğini haber veriyordu. Fransa hükümeti sorunun "tedâbîr-i zecriyeye" başvurulmaksızın halledilmesini içeren bir çözümü ciddi olarak arzu etmekteydi. Bununla birlikte yaptığg ilk teklifin kabul edilmediğini gören Fransa böyle bir çözüm üretilmesi konusunda öncülük etmeyecek olup, Avusturya ve Rusya'nın izlediği politikayı takip edecekti1 ${ }^{115}$.

Fransa'nın pozisyonuna dair Osmanlı hariciyesinin yukarıdaki analizinde iki husus öne çıkmaktadır. Bunlardan birisi Fransa zecrî tedbirlere başvurulmasını istememekte ancak bu konuda İngiltere ve İtalya'yı ikna edemiyordu. Dolayısıyla konu hakkında Avusturya ve Rusya'ya yakın bir çizgide idi. İkinci husus, bir bahriye nümayişi yapılması konusunda Fransız kabinesinin gündemine gelmiş bir teklif ve bu yönde alınmış bir karar yoktu. Ancak bu ikinci husus yukarıda bahsedilen Fransız diplomatik yazışmalarıyla örtüşmemektedir. Fransa Dışişleri Bakanı Rouvier kendisine sorulması üzerine, 24 Ekim'de İngiltere'nin katıldı̆̆ bir bahriye nümayişine olumlu cevap vermişti.

Diplomatik baskının giderek artan ağırlığ yaptıkları müzakerelerdeki tavır ve ifadelere de yansımıştır. Yakın zamanda yayınlanmış olan günlüklerinde Mabeyn İkinci Katibi İzzet Holo Paşa devlet adamlarının Maliye Komisyonu konusunda ve uygulanan baskı karşısındaki reaksiyonlarına dair kendi penceresinden birçok bilgi ve değerlendirmeye yer vermiştir. Öncelikle Almanya sefiri Bieberstein ve öteden beri onun himayesinde hareket eden Sadrazam Ferid Paşa'nın maliye memurlarının kabul edilmesinden yana olduklarına, Ferid Paşa'nın II. Abdülhamid'i birtakım vahim sonuçların ortaya çıkabileceği şeklindeki tehditler üzerinden korkutarak, yapılan teklifi kabul etmeye yönlendirdiğine, bu konuda Almanya ve Avusturya sefirlerine söz verdiğine inanan İzzet Holo Paşa bunu günlüklerinde sıkça vurgulamıştır. Hariciye Nazırı Tevfik Paşa ve İzzet Holo Paşa devlete baskıyla kabul ettirilmek istenilen teklifler karşısında kararlı bir duruş sergilenmesi

115 BOA, Y.A.HUS, 495/57, Lef 3. Paris Sefareti maslahatgüzarından Hariciye Nezareti'ne 1 Kasım 1905 'te gönderilen mahremane tahriratın tercümesi. 
taraftarıyd. İzzet Holo Paşa konu hakkında yapılan Encümen-i Vükela müzakerelerinde, özellikle devletlerin verdikleri notalarda bir tehdit ifadesi olarak geçen "vak'a-i elîme" tabirinin II. Abdülhamid'i korkuttuğunu açıkça ifade ettiğini söylemektedir. Ferid Paşa'yı malî kontrol teklifini kabul etmek için sürekli firsat kollamakla suçlamıştır. Ferid ve eski sadrazam Said paşalar maliye delegeleri teklifinin kabul edilmesi gerektiğini söyleyince onlara karşı çok sert ve saldırgan bir üslupla cevaplar vermişti ${ }^{116}$.

İzzet Holo Paşa'nın mevzubahis düşünceleri ve davranışları onun uygulanan diplomatik baskı karşısında sonuna kadar direnme taraftarı olduğunu açıkça göstermektedir. Bununla birlikte, diğer bazı devlet adamlarına ve özellikle Sadrazam Ferid Paşa'ya yönelik ağır eleştirilerin dile getirilme şekli bazı başka şahsî hesapların olabileceğini akla getiriyor. Öte yandan aşağıda görüleceği üzere Alman sefiri Bieberstein'ın takip ettiği politikaya dair değerlendirmelerinin konjonktürel gelişmeleri iyi okumamasından ve aşırı duygusallıktan kaynaklandığını söylemek yanlış olmayacaktır. Asıl önemlisi Osmanlı devlet adamları arasında diplomatik baskılara sonuna kadar dayanılması gerektiğini savunan Mabeyn İkinci Katibi İzzet Holo ve Hariciye Nazırı Tevfik paşaların başını çektiği bir grubun varlığıdır. $\mathrm{Bu}$ grup meselenin başından itibaren sağlam bir duruş gösterilmesi gerektiğini savunan II. Abdülhamid'in destekçileri olarak, zaman zaman onu ikna ve motive ederek geri adım atılmasını çok uzun süre önleyebilmişti.

\section{Almanya'nın Pozisyonu}

Almanya, Osmanlı Makedonya'sında bir Avrupa malî kontrolü kurulması konusunda dönemin diğer Büyük Güçleriyle fikir birliği içinde olmasına rağmen bunun kabul ettirilmesi için Osmanlı Devleti'ne yönelik bir bahriye nümayişi yapılması düşüncesine, konunun gündeme geldiği ilk andan itibaren soğuk bakıyordu. Yukarıda bahsedildiği üzere, Almanya'nın söz konusu çekimser pozisyonu diğer büyük devletler tarafından fark edilmiş ve diplomatik çevrelerde bahis konusu olmuştu. Osmanlı devlet adamlarının ise Almanya'dan ciddi beklentileri vardı. Almanya'nın lehte alacağı pozisyonun büyük devletlerin ortak bir deniz operasyonunu engelleyebileceğini düşünüyorlardı. Bu düşünce diğer devletlerin diplomatlarının çeşitli ifadelerinde de teyit edilebilmektedir.

İstanbul'daki Alman sefiri Baron Marschall von Bieberstein, Osmanlı Devleti’ne karşı yapılan ortak diplomatik girişimlere destek verirken, konunun bahriye nümayişine doğru evrilmesiyle daha farklı bir tavır almaya başlamıştı. Bu tavır aslında Osmanlı devlet adamları ve bizzat II. Abdülhamid üzerinde şahsî etkisini kullanarak, bahriye nümayişine gerek kalmadan Osmanlı Devleti'nin ikna edilmesiydi. Hatta Rus diplomatlar bunun mümkün olabileceğine bir ara inanmışlardi ${ }^{117}$.

116 Arap İzzet Holo Paşa'nın Günlükleri, I, s. 424-427.

117 St. Petersburg'daki Fransiz maslahatgüzar Boutiron'dan Rouvier'e, 26 Ekim 1905: Documents Diplomatiques Français (1871-1914), 2. Série (1901-1911), s. 118. 
Osmanlı yüksek bürokratları ise Bieberstein'ın giderek tırmanan krizdeki tavrından çok memnun değillerdi. Özellikle İkinci Katip İzzet Holo Paşa açıç̧a Almanya’yı ve Alman sefirini Osmanlı Devleti'ni yeterince ve gerektiği gibi müdafaa etmemekle suçlamışt1 ${ }^{118}$. Sadrazam Ferid Paşa ile Bieberstein arasında Ekim ayında gerçekleşen bir görüşmenin içeriği her iki tarafin beklentilerini anlamak için dikkate değer veriler sunmaktadır. Görüşmede Bieberstein Ferid Paşa’ya maliye memurlarına müsaade edilmesi gerektiğini bir kez daha ifade etmişti. Bieberstein maliye memurlarının üç vilayetin bütçesini düzenlemelerinin ve gelirlerini toplayıp harcamada bulunmalarının Osmanlı saltanatının hukukunu ihlal etmeyeceğini savunuyordu. Bu şekilde sadece Osmanlı Bankası ile yapılan sözleşmenin uygulanması sağlanacaktı. Devletin hukuk ve istiklali herhangi bir şekilde zarar görmeyecekti. Düşüncelerini güçlendirmek için yaklaşık yirmi beş sene önce kurulan Düyûn-1 Umûmiye'nin kesinlikle devletin hukukuna aykırı olmadığını, yine Rumeli'deki üç vilayete daha önce tayin olunan ecnebi memurların devlet ve memlekete maddi hiçbir zarar vermediğini bilakis yabancı görevlilerin bölgede bulunmasının Osmanlı Devleti'nin askerî operasyonlarının dış tenkitlerden kurtulması gibi bir fayda sağladığını savunmuştu. Ferid Paşa karşılık olarak, bütçe denkliğinin sağlanmasının ve mahalli gelir gider idaresinin devlet ve hükümetin hukukunun temel konularından olduğunu söyleyerek, konunun tabiatının ve teferruatının bu şekilde mahzursuz gösterilmesinin de aslında bir baskı olduğunu dile getirmiştir.

Ferid Paşa ise Düyûn-1 Umûmiye idaresinde çalışan ve hiçbir resmî sıfatı bulunmayan memurların konumunun farklı olduğuna ve sınırlı müdahale hakları bulunduğuna, keza ajan siviller ile diğer yabancı memurların görev süreleri ve yetki sınırlarının tespit edildiğine dikkat çekmiştir. Bunların, hiçbir sınırlamaya tâbi olmayan maliye memurları ile kıyas edilmesi mümkün değildi. Birbiri ardına yapılan tekliflerle Osmanlı Devleti'nin şeref ve istiklalinin bahis konu yapılmasının gereksizliğini ve bu yola sürüklenmesine sadık dostu olan Almanya'nın rıza gösteremeyeceğini tüm çıplaklığıyla ifade etmişti. Bunun üzerine Almanya sefiri Osmanlı Devleti'ne uzlaşma önermiştir. Avrupalı Büyük Güçler ile kesin bir şekilde ters düşülerek meçhul bir yola girmektense pazarlık yapılarak bahsi geçen maliye memurlarının görev sürelerinin sınırlanması ve görevlerinin kesin bir şekilde belirlenmesi ile bir uzlaşma zemini aranması gerektiği uyarısında bulunmuştur. Ferid Paşa’nın buna verdiği cevap aslında Osmanlı Devleti’nin konuya bakış açısının özeti gibidir: "hak-1 müdâhalenin tasdîki gibi bir esâsın kabûlü imkân haricinde"dirr"119.

Bahriye nümayişinin giderek somut bir şekle bürünmesi Bieberstein'ın bunu önlemeye yönelik faaliyetlerinin de artmasını beraberinde getirmişti. Fransa maslahatgüzarı Boppe,

118 Arap İzzet Holo Paşa'nın Günlükleri, I, s. 421, 430.

119 BOA, Y.A.HUS, 494/20. Sadrazam Ferid Paşa'dan Mabeyn'e, 10 Şaban 1323 (10 Ekim 1905); Kırmızı, Avlonyalı Ferid Paşa, s. 260-261. 
Kasım ayı başında Bieberstein'ın bahriye nümayişi konusunda ikna olduğunu bildiriyordu ${ }^{120}$. Gerçekte ise durum daha farklıydı. Bieberstein bundan sonraki aşamalarda da Osmanlı hükümetiyle görüşmeye devam ederek, bir uzlaşma sağlamaya çalışmıştı. Silahlı bir bahriye nümayişine katılmakta tereddüt gösteren Almanya, İstanbul'daki sefiri aracılığıyla II. Abdülhamid'in direncinin kırılmasını uzun süre beklemişti. II. Abdülhamid ise Almanya'dan yardım umuyordu. Nitekim Alman Şansölyesi von Bülow’un bahriye nümayişine katılma önerisi imparator II. Wilhelm tarafından kesin bir şekilde reddedilmiştir. Nümayişe katılma teklifleri karşısında Almanya, Akdeniz'de gemisi olmayan Büyük Güçlerin eylemine moral desteği verdiğini söyleyerek, oldukça diplomatik bir üslup kullanmışt1 ${ }^{121}$.

Büyük devletlerin İstanbul'daki sefirleri Babıali'ye son bir nota vererek, taleplerini bildirdikleri sırada Bieberstein hükümetine İstanbul'daki meslektaşlarını tekliflerinde bazı tadilatta bulunmaya ikna ettiğini, eğer Osmanlı Devleti yapılan teklifi kabul etmezse bir bahriye nümayişine maruz kalmasının bu aşamada kaçınılmaz olduğunu, "Devlet-i Aliyye'nin şan u şerefine mugayir şöyle bir halin zuhûruna meydan verilmemesi muvâfik-1 maslahat olacağını beyân" ederek, teklifi kabul etmesini Osmanlı hükümetine dostça tavsiye ve ihtar eylediğini haber vermiştir ${ }^{122}$. Buradan da anlaşıldı̆̆ 1 üzere Almanya bir taraftan büyük devletlerin ortaya koyduğu uyuma bağlı kalmaya çalışmış diğer taraftan ise bir bahriye nümayişine gerek kalmadan meselenin uzlaşmayla çözülmesi için önemli bir çaba içinde olmuştur. Aşağıda görüleceği üzere bu ara bulucu tavrını meselenin sonuna kadar sürdürmüştür. Bu Osmanlı hariciyesine büyük devletlerin İstanbul'daki sefirler arasında yapılan görüşmelerin ve alınan kararların içeriği üzerinde sınırlı da olsa bir etkide bulunma imkanı sağlamıştır.

\section{Bahriye Nümayişi Programı}

Babıali’yi zorlamak adına yapılması düşünülen bahriye nümayişinin, Ekim sonlarından itibaren çalışılmakta olan içeriği Viyana ve Petersburg kabineleri tarafından 8 Kasım itibariyle bütün büyük devletlere ulaştırılmışt1 ${ }^{123}$.

120 Boppe’tan Rouvier'ye, 1 Kasım 1905: Documents Diplomatiques Français (1871-1914), 2. Série (1901-1911), s. 138.

121 Berlin'deki Fransa sefiri Bihaurd'dan Rouvier'ye, 8 Kasım 1905: Documents Diplomatiques Français (18711914), 2. Série (1901-1911), s. 153-154.

122 Berlin'deki Osmanlı sefirinin 14 Kasım'da bildirdiğine göre Bieberstein'ın kabul ettirdiği tadilatlar şunlardı: (1) Rumeli'deki üç vilayeti denetleyecek Maliye Komisyonunun riyaseti daima Osmanlı memurlarında olacaktı, (2) Komisyon hiçbir icra yetkisine sahip olmayacaktı, (3) Yeni bir vergi konulmasında Osmanlı padişahının kanunî hakları ile Osmanlı memurlarının azil ve tebdili hususundaki hükümranlık hukukuna zarar verecek hiçbir maddeye Nizamnamede yer verilmemesi: BOA, Y.A.HUS, 495/95, Lef 2.

123 Londra'daki Fransa maslahatgüzarı Geoffray'dan Rouvier'e, 8 Kasım 1905: Documents Diplomatiques Français (1871-1914), 2. Série (1901-1911), s. 152-153. Bu arada Paris Sefaretinden Hariciye Nezareti'ne gelen 7 Kasım tarihli habere göre başvurulacak zorlayıcı tedbirlere dair program Paris'e ulaşmıştı. Fransız gazeteleri bahriye nümayişine Charlemagne zırhlısı ve Kléber kruvazörünün katılacağına dair haberler yayınlıyordu: BOA, Y.A.HUS, 495/59, Lef 3. 
Plana göre gösteriye katılan her ülke bir savaş gemisi gönderecekti. Daha küçük ölçekte ancak yüksek hıza sahip birçok gemi de keşif ve kurye hizmetlerini yerine getirmek üzere ortak donanmaya dahil edilecekti. Pire Limanı toplanma noktası olacaktı. Bu merkez ayrıca operasyonun sonuna kadar hükümetler, sefirler ve donanma kaptanları arasında gerçekleşecek telgraf iletişimi için de bir merkez görevi görecekti. Böyle bir donanmanın toplanmış olma gerçeği bile tek başına İstanbul'da ciddi bir izlenim bırakma ihtimaline sahipti. Donanma Pire'de üç gün kalacak, geçen zaman içinde Babıali'nin geri adım atmadığı haberi gelmezse Midilli'ye hareket edecekti.

Donanma Midilli'ye ulaştıktan ve ada idaresine resmen haber verildikten sonra, gümrük ve telgrafhane işgal, ticarî faaliyetlerin baltalanmamasına dikkat edilecekti. Midilli'de sekiz günlük bekleme süresinden sonra eğer bir netice alınamazsa bir büyük, bir küçük gemi bırakılarak önce Limni’ye, en sonunda ise Bozcaada’ya gidilip gümrük ve telgrafhanelere el konulacaktı.

$\mathrm{Bu}$ programın birinci ve ikinci kısımlarının hayata geçirilmesinde bahriye komutanları konseyi (Council of Naval Commanders) yetkiliydi. Konsey en yüksek rütbeli komutan tarafından idare edilecek, nümayiş de aynı şahıs tarafından yönetilecekti. Kıdemli ofiçiyalin Babıali ile anlaşmaya varıldığına yönelik haber almasıyla nümayiş sona erdirilecekti.

Nümayişi yapacak ortak donanmanın kumandanlığı Avusturya-Macaristan'a teklif edilmiştir. Gösteriye St. Georg ve Szigetwar gemileri ile katılma kararı alan AvusturyaMacaristan yapılan teklifi memnuniyetle karşılamışt1 ${ }^{124}$.

Rus ve Avusturya hükümetleri gösteriye katılacak ülkelerden, İstanbul'daki sefirlerini bu yönde bilgilendirerek, gemilerin Pire'de buluşma tarihi üzerinde anlaşmaları için talimat vermelerini istemiştir. Nitekim bahriye nümayişine katılacak gemilerin Pire Limanı'nda toplanması için 22 Kasım tarihi belirlenmişti. Bu arada Avusturya sefiri Baron Calice, Fransa maslahatgüzarı Boppe’tan Fransa'nın 1901 yılında Osmanlı Devleti’ne karşı gerçekleştirmiş olduğu bahriye nümayişinin detaylarını anlatmasını istemişti. Ayrıca diğer sefirler Boppe’tan nümayişi gerçekleştirecek kumandanlar için kısa bilgi notları hazırlanmasını istemişlerdir. Kumandanlara nümayişin bütün aşamalarının yer aldığı bir program ve hizmetlerine de birer dragoman verilmişti ${ }^{125}$.

Bu aşamada artık Almanya'nın yapılacak bahriye nümayişine bir gemi göndermeyeceği kesinleşmişti. Konu hakkındaki sorulara Alman diplomatlar, II. Wilhelm'in formüle ettiği gibi, ülkelerinin Akdeniz'de gemisinin bulunmadığı cevabını vermekteydiler. Fransa'nın Londra maslahatgüzarı Geoffray’a göre Almanya yapılacak bir bahriye nümayişine katılmamakla Rus Çarı II. Nikolay’1, katılmakla ise II. Abdülhamid'i memnun etmeyecekti.

124 Lansdowne'dan E. Goschen'e, 15 Kasım 1905, Further Correspondence Respecting the Affairs of Southeastern Europe, nr. 118, s. 78.

125 Documents Diplomatiques Français (1871-1914), 2. Série (1901-1911), s. 181. 
İngiltere Dışişleri Bakanı Lansdowne donanma gösterisi yapmakla malî bir külfete maruz bırakılan Büyük Güçlerin sırf Maliye Komisyonu'nun onaylanmasıyla yetinmemesi gerektiğini düşünüyordu. İngiliz Hükümeti II. Abdülhamid'e komisyonun çalışma usullerine dair Nizamnamenin (reglement) yanında Komisyon tarafindan belirlenecek reform planının Makedonya mahkemelerinin yeniden organizasyonunu içermesinin de kabul ettirilmesi gerektiği görüşündeydi. Bu görüşünü başta Rusya ve Fransa sefirleri olmak üzere büyük devletlerin Londra' daki diplomatik temsilcileriyle paylaşmışt1 ${ }^{126}$.

İngilizlere göre en önemlisi II. Abdülhamid'i takip ettiği engelleyici taktiklerin sadece kendi maksadını alt ettiğine ikna etmekti. Eğer II. Abdülhamid haftalar, aylar süren engellemelerinden sonra işin en başında ileri sürülen şartlarla "paçayı kurtarmasına" Büyük Güçler tarafından müsaade edildiğinin farkına varırsa, bundan sonraki vakıalarda da benzer taktiklere başvurmaya cesaret edebilecekti1 ${ }^{127}$. İngiltere'nin bir donanma gösterisi sonucunda Osmanlı Devleti'ne kabul ettirilecek şartların genişletilmesini gerekli görmesine karşılık Fransa hükümeti Makedonya'da yapılacak bir adlî ıslahatın da listeye dahil edilmesi şeklindeki İngiliz yaklaşımına pek sıcak bakmıyordu ${ }^{128}$.

\section{Bahriye Nümayişine Konu Olan Tekliflerin Osmanlı Devleti’ne İletilmesi}

Yukarıda bahsedildiği üzere, Maliye Komisyonu dört devlet tarafından tayin edilen maliye delegeleri ve Avusturya ve Rusya'nın daha önce atadıkları ajan sivillerden müteşekkil olarak Üsküp'te çalışmalarına başlamıştı. Bir süre kendi işleyişi ve vazifelerine ait bir nizamname hazırlanmakla meşgul olan Komisyon çalışmalarını tamamlayarak, hazırladığı nizamnameyi büyük devletlerin İstanbul'daki sefirlerine sunmuştu. Sefirler Baron Calice'in konağında toplanarak nizamnameyi incelemişlerdir. Bu toplantıda Alman sefir Baron Marschall von Bieberstein yazılı olarak çeşitli şartlar sunmuştur. İçerik olarak maliye delegelerinin yetki ve güçlerinin sınırlandırılmasını isteyen bu belge üzerinde uzun bir tartışma yapılmış, nihayet diğer sefirlerin özellikle de İngiliz sefirinin belge üzerinde bazı müdahalelerde bulunmasına müsaade edilmiştir. Sonuç itibariyle üzerinde bütün sefirlerin mutabık kaldığı metin, Maliye Komisyonu'na Makedonya'da Büyük Güçlerin amaçladıkları reformları hayata geçirebilmek için gerekli yetkiyi sağlıyordu. Aynı toplantıda ertesi gün Babıali’ye, Maliye Komisyonunun kurulmasını ve hazırlanan ve büyük devletlerin sefirlerince onaylanmış bulunan Nizamnameyi kabul etmesini isteyen son bir nota verilmesinde uzlaşılmıştır. Notada ayrıca Avusturya

126 Documents Diplomatiques Français (1871-1914), 2. Série (1901-1911), s. 152.

127 Landsdowne'dan Mr. Sprig Rice'a, 6 Kasim 1905, Further Correspondence Respecting the Affairs of Southeastern Europe, nr. 113, s. 76-77. Avusturya-Macaristan maslahatgüzarı ile İngiltere Dışişleri Bakanı arasında, gösteriye katılacak İngiliz gemilerinin belirlenip belirlenmediği konusunda yapılan görüşmede İngiltere yeniden Maliye Komisyonu haricinde, II. Abdülhamid'e Nizamname ve mahkemelerde reform yapılmasının da kabul ettirilmesi gerektiği yönünde ısrarcı olduğu ve hareketten önce bu konuya diğer devletlerin dikkatini çekmeye çalıştı̆̆ anlaşılmaktadır: aynı belge, nr. 114, s. 77.

128 BOA, Y.A.HUS, 495/89, Lef 1. 
ve Rusya hükümetlerinin, ajan sivillerin görev sürelerinin iki sene daha uzatmaya karar verdikleri, aynı şekilde Rumeli genel müfettişi ile jandarmanın yeniden düzenlenmesiyle görevli subayların yetkilerinin de iki sene için uzatıldığı bilgisi yer alacaktı ${ }^{129}$.

Büyük devlet sefirleri üzerinde uzlaştıkları notayı, ekinde Maliye Komisyonu'nun görev ve çalışma usullerini düzenleyen Nizamname olduğu halde 15 Kasım 1905'te Osmanlı Hariciye Nezareti'ne göndermişlerdi. Bu, konu hakkında Osmanlı Devleti'ne sunulmuş yedinci nota idi. Osmanlı Devleti bir kez daha Maliye Komisyonu'nun kurulmasını kabule davet edilmişti. Yukarıda bahsedilen kararları da Babıali'ye tebliğ eden sefirler, bu arada Hüseyin Hilmi Paşa'ya Mürzsteg Programı'nın öngördüğü düzenlemeleri tamamen tatbik etmek üzere tayin olunan görev süresinin yeterli olmamasından, altı büyük devletin taleplerine sürekli muhalefette bulunduğunu iddia ettikleri Babıali’yi suçlamışlardır. Bu yüzden de adı geçenin görev süresinin aynı süre için uzatılmasını istemişlerdi ${ }^{130}$. Osmanlı Devleti'nden vakar ve haysiyetini muhafaza etmek adına notadaki kararları kabul etmesini istemişler, aksi halde daha önce bildirdikleri tedbirleri hayata geçirmenin elim mecburiyetine başvuracakları tehdidini tekrarlamışlardı ${ }^{131}$.

Diğer taraftan büyük devletler Osmanlı hükümetinin yapılan teklifleri reddetmesi halinde nasıl bir zorlayıcı diplomasi takip edeceklerine dair planlarını tamamlamışlardı. Osmanlı devlet adamları sürekli gündeme getirilen bu tehdidin mahiyeti ve detayları hakkında bilgi sahibi değillerdi. Osmanlı belgelerinde bu konu uzun süre devletlerin önceden başvurulacağını ima (işrab) ettikleri tedbirler ifadesiyle, oldukça soyut bir biçimde yansımıştı.

Osmanlı Devleti bu son notaya hemen bir cevap vermemiştir. Bunun nedeni Osmanlı sefirlerinden bulundukları devletler nezdinde birtakım diplomatik girişimlerde bulunmaları ve Avrupa ve Amerika basınında lehte bir kamuoyu oluşturulmak istenmiş olmasıdır. Bu hususlara aşağıda değinilecektir. Bununla birlikte bahriye nümayişine katılacak devletlerin donanmalarını Pire Limanı'nda topladıkları gün verilecek cevap konusunda Babıali'de bir hareketlilik yaşandığı anlaşılıyor. Nitekim II. Abdülhamid 22 Kasım akşamı saat sekizde Sadrazam Ferid ve Hariciye Nazırı Tevfik paşalardan Almanya sefiri Bieberstein ile görüşmelerini istemiştir. Sefir bu sırada Tarabya'daki yazlık sefarette bulunduğundan bu görüşme ertesi sabaha kalmıştır ${ }^{132}$. Ertesi sabah Tevfik Paşa'nın konağında bir görüşme gerçekleştirilmiştir.

129 Boppe'tan Rouvier'ye, 14 Kasım 1905: Documents Diplomatiques Français (1871-1914), 2. Série (19011911), s. 180-181.

130 Büyük devletlerin Rumeli genel müfettişi olarak Hüseyin Hilmi Paşa’nın görev süresinin uzatılmasını talep etmelerinin arkasında Makedonya için öngörülen reformların hayata geçirilmesinde kendisinin önemli bir kefil olarak görülmesi bulunuyordu. Bir ara istifa ettiğine dair söylentiler çıkan Hüseyin Hilmi Paşa'nın istifasının kabulünün Osmanlı Devleti'nce maliye kontrolü konusunun reddedileceğine kesin bir şekilde karar verildiği gibi yorumlanarak, bu takdirde hemen tedâbîr-i zecriye ittihâzına ve işe bahriye nümayişiyle başlanacağına dair Peşte Başşehbenderi tarafından 24 Ekim tarihinde bir gazete haberi iletilmiştir: BOA, Y.A.HUS, 495/109, Lef 3.

131 BOA, Y.A.HUS, 495/88, Lef 4; YEE, 50/76, 19 Ramazan 1323 (17 Kasım 1905) tarihli hususî tezkire; Sowards, Austria's Policy of Macedonian Reform, s. 59.

132 BOA, Y.A.HUS, 495/115. 
Altı devletin teklifini henüz kabul etmemesini esef duyulacak bir husus olarak niteleyen Bieberstein, bunu Osmanlı Devleti'nin konunun ehemmiyetini ve vahametini anlayamamış olmasına bağlamıştı. Konuya fazlasıyla önem atfeden büyük devletler ise tekliflerini bir an önce Osmanlı Devleti'ne kabul ettirmek için ne gerekiyorsa yapılmasına karar vermişlerdi. Bunların başvuracakları "tedâbîr-i tazyikiye" sadece bahrî nümayiş ile sınırlı kalmayıp Osmanlı adalarından bazılarını ortak kuvvet ile işgal etmeye kadar varacaktı. İşin bu noktaya getirilmiş olması Osmanlı Devleti açısından oldukça zararlı ve vahimdir. Almanya'nın pozisyonuna da değinen Bieberstein, ülkesinin ne maliye delegesi ne de sair hususlarla ilgilendiğini, itilafa sadece konuyu Osmanlı Devleti lehine idare edebilmek için dahil olduğunu, yapılması planlanan bahriye nümayişine de gemi ve asker göndermediğini vurgulamıştı. Almanya'nın bu tutumunun diğer devletlerce kararlaştırılmış olan tedbirlerin uygulanmasını önleyemeyeceğini açıkça belirmiştir.

Tevfik Paşa ise Maliye Komisyonunu lüzumsuz görmekte olan Osmanlı Devleti'nin ajan sivillerin görev sürelerinin iki sene için uzatılmasını kabul etmesinin büyük bir uzlaşma olacağını ve büyük devletlerin bununla yetinmeleri gerektiğini etraflıca izah etmişti. Bu cevaptan tatmin olmayan Bieberstein konuşmanın başındaki sert üslubunu sürdürerek, kesin ifadelerle ortadaki tehlikenin ciddi olduğunu, Osmanlı Devleti'ni bir felaket yaşanmadan önce ikaz etmeyi görev bildiğini söyleyerek, uyarısının padişaha arz edilmesini istemişti. Görüşmenin sonunda Bieberstein, Maliye Komisyonu hakkında ikna edici bazı görüşleri dile getirmiştir. Buna göre, iki seneliğine kurulan Maliye Komisyonuna sürenin bitiminde tamamen son verileceğini beyan etmiş olan büyük devletlerin sözü bir senet olarak kabul edilmeliydi. Bu süre zarfinda Osmanlı hükümetinin bölgedeki menfaatlerinin korunması ve savunulması Rumeli Genel Müfettişinin dirayeti ve basiretine bağlı olacaktı. Bölgedeki Osmanlı hükümranlığı ise asla zarar göremeyecekti, zira Maliye Komisyonu askerî masraflara ve devletin icraatlarına hiçbir şekilde müdahale etmeyecekti. Ret cevabında devam edilmesi ise gayet vahim ve hükümetin şerefine dokunur sonuçlar doğuracakt $1^{133}$.

Osmanlı Devleti sunulan teklifleri 23 Kasım öğleden sonra verdiği bir nota ile reddetmiştir ${ }^{134}$. İstanbul'daki sefirler adına Baron Calice'e iletilen cevapta Berlin Antlaşması'nda bölgeye yönelik belirlenen maddelerin neredeyse tamamının Osmanlı Devleti tarafından yerine getirdiği ifade edilip, bunlar başlıklar halinde sayıldıktan sonra, bunun tek bir nedeni olduğu vurgulanmıştır. $\mathrm{Bu}$ neden Osmanlı hükümetinin bağımsızlığının ve bütünlüğünün hiçbir zarar ve ziyan görmesinin istenmemesiydi. Dolayısıyla Osmanlı Devleti, Rumeli'deki üç vilayette meydana gelen olaylardan mesul tutulmamalıydı. Olaylar Hristiyan unsurların kendi aralarındaki nefret ve dışarıdan yapılan müdahalelerden kaynaklanmaktaydı. Büyük Güçler de

133 BOA, Y.A.HUS, 495/115, Lef 2. Hariciye Nazırı Tevfik Paşa’nın 25 Ramazan 1323 (23 Kasım 1905) tarihli takriri; Kırmızı, Avlonyalı Ferid Paşa, s. 263.

134 O'Conor'dan Lansdowne'a telgraf, Further Correspondence Respecting the Affairs of South-eastern Europe, nr. 124 , s. 93. 
bunun farkındaydılar. Babıali kabul ettiği önlemleri en kısa sürede yerine getirmeye çabalamıştı. Osmanlı Devleti bundan dolayı, bağımsızlık ve bütünlüğünü garanti eden antlaşmalara aykırı olarak, maliye delegelerinin göreve başlamasında ısrar edilmesini anlamsız bulmakta, bu konudaki ısrarı bağımsızlığına aykırı görmekteydi. Yine de ajan sivillerin görev sürelerinin iki sene daha uzatılmasına, kendilerine tanınan yetkileri aşmamak kaydıyla, razı olacaktı. Babıali verdiği cevabın sonunda, Büyük Devletler olayları istedikleri gibi görmekte 1srar edip daha fazla baskı yaparlarsa doğacak sonuçlardan, aynı şekilde Osmanlı ahalisinde oluşacak memnuniyetsizlikten sorumlu tutulamayacağını bildirmişti ${ }^{135}$. Anlaşılacağı üzere bu cevap, Tevfik Paşa'nın Almanya sefiri Baron Marschall von Bieberstein'a kısa süre önce yaptıkları görüşmede söyledikleriyle birebir aynı idi.

Babıali'nin kararlı duruşu ve sefirlere bir kez daha ret cevabı vermesi Avrupa'daki siyasî mahfillerde heyecana neden olmuştu. Fransa'nın Viyana'daki sefiri Reverseaux'nun bildirdiğine göre Dışişleri Bakanı Kont Gołuchowski bu direnişi Almanya'nın bahriye nümayişi konusunda çekimser kalmasına bağlamış, yine de dört büyük devletin istekleri karşısında Babıali’nin geri adım atacağından şüphe duymamışt ${ }^{136}$.

\section{Osmanlı Devleti’nin Yurt Dışında Kamuoyu Oluşturma Çabaları}

Osmanlı Devleti yoğun diplomatik baskılar ve uluslararası arenada basın aracılığı ile oluşturulan aleyhteki kamuoyu algısına karşılık vererek, hukuk ve bağımsızlığına yönelik bir müdahale olduğunu anlatmaya çalışmıştır. Bu konuda Avrupa ve ABD'nin saygın gazetelerinde haberler yayınlatmak şeklinde bir strateji takip edilmiştir. Yurt dişındaki Osmanlı diplomatları süreç içinde özellikle Bulgaristan menşeli haberleri takip ve tekzip etmekteydiler. Bunların dışında, son dönem Osmanlı bürokratik kadrosunda bilhassa geniş hukuk ve diplomasi bilgisiyle öne çıkmış Grigor Aristarki (Aristarchi) Bey’in kaleme aldığı, Osmanlı Devleti'nin durumunu hukukî zeminde ortaya koyan makaleler yurtdışında saygın gazetelerde yayınlatılmıştır.

Aristarki Bey, Rum asıllı olup idarî ve bürokratik geçmişe sahip bir ailenin çocuğu olarak dünyaya gelmiş, Avrupa'da hukuk eğitimi almış, diğer bazı diller yanında iyi derecede Fransızca ve İtalyanca bilen, çok çeşitli mülkî ve bilhassa diplomatik görevlerde bulunmuş, kalemi kuvvetli, hukuk alanında önemli eserler vermiş bir kişiydi ${ }^{137}$.

Hariciye Nazırı Tevfik Paşa, Kasım 1905'in ilk günlerinde Aristarki Bey’den Paris Sefareti'nde bulunan evrak ve delilleri kullanarak Osmanlı Devleti'nin kendisine zorla kabul

135 Documents Diplomatiques Français (1871-1914), 2. Série (1901-1911), s. 213-214.

136 Viyana'daki Fransa Sefiri Reverseaux'dan Rouvier'ye, 25 Kasım 1905: Documents Diplomatiques Français (1871-1914), 2. Série (1901-1911), s. 220.

137 Taceddin Kayaoğlu, Osmanlı Hâriciyesinde Gayr-i Müslimler (1852-1925), Türk Tarih Kurumu Yayınları, Ankara 2013, s. 112-114. 
ettirilmek istenilen Maliye Komisyonu'nun kurulmasına karşı haklı itirazını konu edinen birkaç makale yazmasını istemişti ${ }^{138}$. Bu tarihte yaşı itibariyle bazı sağlık sorunları olduğu anlaşılan Aristarki Bey, konu hakkında Osmanlı hukuku ve menfaatlerini savunan makaleler kaleme alarak, bunları Fransa, İngiltere ve ABD’nin önemli gazetelerinde yayınlatmıştır.

Aristarki Bey'in kaleme aldığı ilk makale, yayınlanmak üzere Paris sefareti maslahatgüzarı Nabi Bey tarafından 3 Kasım'da Paris’te Deba (Journal des Débats) gazetesine gönderilmiştir ${ }^{139}$. Aristarki Bey tarafindan ortaya konulan görüşlerden memnun olan II. Abdülhamid' in isteğiyle makale Avrupa'nın diğer gazetelerine de gönderilmiştir ${ }^{140}$.

Uygulanan diplomatik baskı ve muameleye, hukukî ve tarihî argümanlar ortaya koyarak Osmanlı Devleti'nin verdiği cevap olan bu yazı, konuya resmî bakışı ve yaklaşımı sunmaktadır. Öneminden dolayı bu çalışmanın ekinde tam transkripsiyonu verilen makalenin girişinde büyük devletlerin Osmanlı hükümeti tarafından ihlal edilmiş birtakım hukuku müdafaa için zorlayıcı tedbirler alacaklarından bahsedildiği ifade edilerek, böyle bir yola başvurulmadan önce her devlete düşen sorumluluğun neler olduğunun belirlenmesi gerektiğine dikkat çekilmiştir.

Osmanlı Devleti, Aristarki Bey'in kalemiyle ortaya koyduğu temel argümanını 1878'de imzalanan Berlin Antlaşması'ndan belirlenen şartlar dahilinde bağımsızlığının ve bütünlügüünun devam etmesi ve korunması gerektiği üzerine kurmuştur. Bahsi geçen antlaşmalardan doğan yükümlülüklerini yerine getirmiş olmasına rağmen, Avrupa'nın taraflı bakışı, uygulamaları ve baskılarına maruz kalmaktadır. Antlaşma maddelerini yerine getirmeyen Balkan devletleri ise Avrupa tarafından hoşgörüyle karşılanmaktadır. Uygulamalardan, özellikle de Şark Meselesi'ne dair olanlarda fikir birliği 1870'ten beri genel bir kaide olarak Avrupa tarafından kabul edilmiş ve daima uygulanmış olmasına rağmen, 1878 tarihinden beri Osmanlı Devleti'ne fayda ve çıkar sağlayabilecek durumlarda değişmez şekilde dikkate alınmamıştır. En son kabul ettirilmek istenilen malî kontrol konusu da hukuk dışı ve gayri meşru, keyfi bir uygulamadır. Padişahın hukuk ve haysiyetini ihlal etmektedir. Babıali buna boyun eğmediği takdirde bazı zorlayıcı tedbirlere maruz bırakılacağı açıklanmaktadır. Çünkü Avrupa devletleri nüfuz ve iktidarlarına bu derece zarar gelmesine rıza göstermemektedirler. Berlin Antlaşmasına aykırı olan malî kontrol konusu Osmanlı Devleti tarafindan bid'at olarak görülmektedir. Herhangi bir ihtiyaca ve lüzuma dayanmamakta olup Osmanlı Devleti Mürzsteg Programı'nın gerektirdiği bütün uygulamaları iyi niyetle yerine getirmiş ve idarî masrafların tamamını karşılamış olmasına rağmen bu dayatmada ısrar edilmesi anlaşılmaz bir durumdur. Aristarki Bey mütalaasına, Avrupa diplomasisinin Osmanlı Devleti ile olan ilişkisinde artık bir kaide halini almış gibi görünen keyfi harekete karşı hiçbir hükmü olmayacağını söyleyerek bitirmiştir.

138 Y.A.HUS, 495/121, Lef 1; Kayaoğlu, Osmanl Hâriciyesinde Gayr-i Müslimler, s. 115.

139 BOA, Y.A.HUS, 495/121, Lef 4.

140 BOA, Y.A.HUS, 495/121, Lef 3; BOA, Y.A.HUS, 495/65, Lef 1. 


\section{Diplomatik Baskı Altında Yürütülen Pazarlık}

Rus hükümetinin gözlemlerine göre, baskılar karşısında II. Abdülhamid, Büyük Güçleri bölebileceği umuduyla, karar verdikleri eylemi ortadan kaldırana kadar mücadele etmeyi sürdürecekti ${ }^{141}$. Nitekim nümayiş için Pire'de toplanmış gemilerin limandan ayrılacağı gün Hariciye Nazırı İstanbul'daki Avusturya ve İngiltere sefaretlerini ziyaret edip, şahsî ancak sultanın tüm yetkilerine sahip olarak uluslararası bahrî nümayişin durdurulmasını talep etmiştir. Tevfik Paşa Avusturya sefiri Baron Calice'e ve İngiliz Sefiri O'Conor'a Osmanlı hükümetinin Büyük Güçlerin önerilerini bazı şartlar dahilinde kabul ettiğini bildirmiştir. Böylece büyük devletlerin ortak donanmalarının fiili baskısı altındaki Osmanlı Devleti açısından bir pazarlık süreci başlamıştır. Nitekim bahriye nümayişi başladıktan sonra da taraflar arasında diplomatik görüşmeler devam etmiştir.

Osmanlı Devleti'nin şartları şunlardı: (a) Maliye delegeleri yerine malî danışman sıfatı kullanılacaktı, (b) maaşları Osmanlı hükümetince ödenecekti, (c) sunulan Nizamnamenin 10. maddesinde bahsi geçen müfettişler Osmanlı hükümetince atanacaktı. Bu şekilde bir uzlaşmaya gitmek mümkün olabilecekti. Tevfik Paşa, çözümde bu yönde bir kolaylaştırma sağlanması durumunda Babıali'nin büyük devletlerin diğer taleplerini kabul etmesinin daha kolay olacağını söylemişti.

Baron Calice söz konusu şartların değerlendirilmesi için artık çok geç olduğunu ifade etmiş, Büyük Güçlerin tam manasıyla tatmin edilmeleri söz konusu olmadan bahriye nümayişinin durdurulması için bir şey yapılamayacağını belirtmişti. Teklifi diğer meslektaşlarıyla paylaşacağını ve en kısa zamanda üzerinde mutabık kalınmış bir cevabı ileteceğini de söylemişti ${ }^{142}$.

O’Conor ise şahsî görüşü olmak kaydıyla verdiği cevapta bir uzlaşma için zamanın geçtiğini, Babıali'nin Büyük Güçleri bir donanma gösterisinde bulunmaya zorladığını, bu gösterinin muhtemelen onların taleplerini azaltıcı değil artırıcı bir etki yapacağını söylemiştir. O'Conor, hâlâ ortada sonraki gelişmelerden kurtulmak için zaman olduğunu, eğer mevcut şartlara rıza gösterirse Babıali'nin akıllıca hareket etmiş olacağını düşünmektedir ${ }^{143}$.

Osmanlı Devleti'nin büyük devletlerin İstanbul'daki sefaretleri adına hareket eden ve görüşmeleri yürütmekte olan Avusturya Sefiri Baron Calice yanında, İngiliz sefiri O'Conor'a aynı şartlarla müracaat etmesi dikkatlerden kaçmamalıdır. Bu hareket Osmanlı Devleti’nin kendisine karşı yürütülmekte olan diplomatik baskıda İngiltere'nin rolünü iyi okuduğunu göstermektedir.

141 Documents Diplomatiques Français (1871-1914), 2. Série (1901-1911), s. 153-154.

142 Boppe'dan Rouvier'e, 25 Kasım 1905: Documents Diplomatiques Français (1871-1914), 2. Série (19011911), s. 221-222.

143 O'Conor'dan Lansdowne'a telgraf, 25 Kasım 1905: Further Correspondence Respecting the Affairs of Southeastern Europe, nr. 128, s. 95. 
Artık bu aşamada, yapılacak bahriye nümayişi tamamen büyük devletlerin İstanbul'daki diplomatik temsilcilerinin kontrolündeydi. Sefirler Babıali’nin son dakika teklifini kendi aralarında değerlendirmişlerdi ${ }^{144}$. Nitekim altı büyük devlet adına Baron Calice, 26 Kasım 1905 tarihinde Babıali’ye maliye delegesi unvanının malî danışmana çevrileceğini ve eğer Osmanlı hükümeti bu akşam sekize kadar, tüm taleplerin kabul edildiğini yazılı olarak bildirirse Midilli'deki operasyonların durdurulacağını bildirmişti.

Hariciye Nazırı Tevfik Paşa saat 18:00'de bir katip vasıtasıyla, Baron Calice'e haber göndererek, konunun Meclis-i Vükela'da ele alındıktan sonra yayınlanacak bir irade ile onaylanması gerektiğinden, sefirlerden iki ya da üç günlük bir öteleme istemişti. Sefirler ise müttefik donanmanın planlarının değiştirilmesi için hiçbir sebep görmemişlerdi ${ }^{145}$.

Aşağıda bahsedileceği üzere, ortak donanmanın 26 Kasım'da Midilli Adası'na asker çıkarmasından sonra Osmanlı Devleti diplomatik girişimlerini artırmıştır. Sadrazam Ferid Paşa iki defa Rusya sefiri Zinovieff'i, Hariciye Nazırı Tevfik Paşa İtalya Sefiri Imperiali’yi ve İkinci Katip İzzet Paşa Almanya sefíri Bieberstein'1 ziyaret etmiştir. Görüşmelerin hepsinde benzer cevaplar alınmıştır. Olayların geldiği noktada artık müzakere imkanının bulunmadığı ve Babıali'nin direnmeye son vermesi gerektiği söylenmişti. Bu olmaksızın hiçbir sefir nümayişi durdurma ya da mevcut talepleri tadil etme girişiminde bulunamazd. Osmanlı Devleti'nin Londra ve Viyana'daki sefïleri de iki ülkenin dışişleri bakanlarıyla birer görüşme gerçekleştirmiştir. Viyana'da kendisiyle görülen Osmanlı sefirine karşı ciddi bir lisan kullanan Dışişleri Bakanı Gołuchowski’ye göre, Babıali'nin iddia ettiği gibi teklif olunan reformlar, Makedonya'nın Osmanlı Devleti'nden ayrılmasını değil, tam tersine bölgenin Osmanlı Devleti hakimiyetinde kalmaya devam etmesini amaçlamaktaydı. Osmanlı sultanının da bunu anlaması gerekiyordu. Eğer sultan bu tavrını sürdürmeye devam ederse, Avusturya ve Rusya devletleri diğer büyük devletlerin politikasını uygulamak, Makedonya için özerklik talep etmek zorunda kalacaktı ${ }^{146}$. Kont Gołuchowski'nin bu cevabı daha önce İngiliz diplomatik çevrelerince şikâyet edildiğinden bahsedilen, Osmanlı Devleti'ni İngiltere'nin radikal istekleriyle korkutarak, Avusturya-Rusya çizgisine razı etme çabasının diğer bir örneğidir.

144 Boppe'tan Rouvier'ye, 25 Kasım 1905: Documents Diplomatiques Français (1871-1914), 2. Série (19011911), s. 221-222.

145 O'Conor'dan Lansdowne'a telgraf, 26 Kasım 1905: Further Correspondence Respecting the Affairs of Southeastern Europe, nr. 131, s. 96; Documents Diplomatiques Français (1871-1914), 2. Série (1901-1911), s. 226227.

146 Konuyu 27 Kasım tarihli telgraf ile Dışişleri Bakanı Rouvier’ye aktaran maslahatgüzar Boppe, Baron Calice'in kendisiyle paylaştığı Gołuchowski'nin çok gizli ibareli telgrafındaki bilgileri başkasıla paylaşmaması ricasında bulunduğunun altını çizmiştir: Documents Diplomatiques Français (1871-1914), 2. Série (19011911), s. 226-227. 


\section{Bahriye Nümayişinin Başlaması}

Osmanlı Devleti son dakika gerçekleştirdiği diplomatik girişimlerden netice elde edememiş ve beş büyük devletin gemilerinden oluşan donanma, planlandığ 1 üzere 26 Kasım 1905 tarihinde Midilli Adası'na asker çıkarmıştır. Böylece Osmanlı Devleti’ni dize getirmek isteyen devletlerin 17 Aralık'a kadar sürecek olan, Midilli ve ardından Limni adalarının işgal edileceği donanma gösterileri başlamışt1 ${ }^{147}$.

Midilli'ye çıkarılan askerler telgrafhane ve gümrük binasını işgal etmişlerdi. Mutasarrıf Galib Paşa, işgali derhal protesto etmişti ${ }^{148}$. Midilli Mutasarrıflığından işgali haber veren telgraflar gelmesi üzerine "hukuk-1 düvel kavâidine külliyen mugāyir olan ve hiçbir hak ve salâhiyete müstenid bulunmayan hareket-i vakı'aya karşı tekrar protesto edilmesi mutasarrıflığa derhal iş'âr" olunmuş ve Babıali tarafından da gereği gibi protesto edilmesi Hariciye Nezareti'nden istenmişti. Asıl adım ise konu hakkında Meclis-i Vükela' da verilecek karardan sonra atılacakt ${ }^{149}$.

Midilli'deki işgal ve müttefik donanmasının hareketleri hakkında bilgi alabilmek için Erkan-1 Harbiye-i Bahriye Mülazım-1 Evvellerinden Vahid Efendi Yunan posta vapuruyla adaya gönderilmiştir. Vahid Efendi İngiliz, Avusturya, Fransa, İtalya ve Rusya devletlerine ait zırhlı ve torpidolardan meydana gelen 10 savaş gemisinin "abluka tertibinde" ada yakınında demirlemiş olduklarını görmüştür. Bulunduğu posta vapuru da teftişe tâbi tutulan Vahid Efendi bir fırsatını bularak adaya sızmıştır.

Vahid Efendi'nin verdiği malumata göre müttefik filo Pire'den gelerek önce limanın farklı noktalarından sahile 700 asker çıkarmıştı. Ardından yerel hükümete bazı mevkilerin işgal edileceğini resmen bildirmiş, bunun üzerine protesto olunmuştu. Gümrük ve telgrafhaneyi işgal eden askerler, gümrük hasılatına da el koymuştu. Her devlet askeri 24 saatte bir diğer devlete karakol nöbetini devrediyordu. Haberleşmek için limanın sahilinde kumandan gemisi

147 İşgale katılan devletlerin kaptanları, P. Kolionpanof, N. Gozo, A. Cros, H. Loftus Tottenham, J. De Ripper idi. Sekreterlik ise İngiliz sefaretinden görevlendirilen Winterhalder tarafından yapılıyordu. İngilizler, Lancaster ve Sentinel gemileri ile katılmışlardır. İngiliz güçleri Kaptan H. Loftus Tottenham'ın kumandası altındadır. Uluslararası operasyonun idaresi Avusturyalı Amiral Von Ripper tarafından gerçekleştirilmiştir. Kaptan Tottenham ve von Rippen müttefik donanmanın en yüksek rütbelileridir. İngilizlerin bu donanma gösterisine verdikleri gemiler Vice-Admiral Lord Charles Beresford'un idaresi altında bulunan Akdeniz Filosu'ndan ayrılmışlardı. TNA, FO, 371-145, No. 2181.

148 Midilli'nin müttefik devletlerin donanmaları tarafından işgal edilmesi üzerine durumu protesto eden Mutasarrıf Galip Paşa'nın tavrından memnun olan II. Abdülhamid, “Bâbıâlî’nin işgal karşısında devletleri protesto etmesi gerekmez mi idi (?)” diye sorarak açıklama istemiştir: BOA, İ.HUS, 136/1323 L-1; 29 Kasım 1905.

149 Bunun yanında Babıali'nin de ayrıca devletleri protesto etmesi gerekip gerekmeyeceği Padişah tarafından yeniden sorulmuştur. Verilen cevapta, büyük devletlerin böyle bir harekette bulunacağı haber alınmasıyla, Galip Paşa’ya Babıali tarafından önceden gerekli talimat verilmiştir. Paşa'nın protestosu söz konusu talimat uyarınca gerçekleşmiştir. Bunun dışında son verilen notanın son maddesi zaten protestoyu muhtevi bulunmakta olduğu belirtilmiştir: BOA, YEE, 50/78; 29 Kasım 1905. 
olan İngiliz zırhlısına telgraf kablosu uzatılmıştı ${ }^{150}$. Bir süre sonra Midilli' de dört yüz kadar asker bırakan müttefik donanması Bozcaada ve Limni istikametine hareket etmiştir ${ }^{151}$.

\section{Osmanlı Devleti'nin Yeni Teklifleri}

Maliye Komisyonu konusu, beş devletin gemilerinden oluşan ortak filonun bahriye nümayişine başlamasıyla farklı bir aşamaya girmiştir. Rumeli ıslahatını bir iç mesele olarak görmekte 1srar ederek, kendisini bu şekilde müdafaa etmeye çalışan Osmanlı Devleti, uygulanan diplomatik baskı ve şiddet karşısında bazı yeni adımlar atmak zorunda kalacaktı. Bir taraftan tayin edilen delegelerin Osmanlı hizmetine girmelerini teklif ederken, diğer taraftan ilgili devletlerin başkentlerinde bulunan diplomatik temsilcilerine dayatılan taleplerin tadil edilmesi için çalışmaları talimatı verilmişti.

$\mathrm{Bu}$ aşamada Osmanlı hükümeti dört devlete, tayin etmek istedikleri maliye delegeleri yerine, Avusturya ve Rusya tarafından daha önce atanmış ajan sivil unvanlı, birebir aynı yetkilere sahip görevliler istihdam edilmesini kabul ettirmeye çalışmıştı. İngiliz sefiri O’Conor sadrazam adına görüşmeye gelen Hariciye Nazırı Tevfik Paşa'ya İngiltere'nin neden Maliye Komisyonu kurulmasını gerekli gördüğüne dair bazı açıklamalarda bulunmuştu. O’Conor'a göre, Mürzsteg Programı kapsamında planlanmış reformları atadıkları ajan siviller aracılığıyla hayata geçirmeye çalışan Avusturya ve Rusya iki senenin sonunda başarısız olmuştu. Bunun üzerine adı geçen iki ülke, Makedonya maliyesinin yeniden düzenlenmesi konusundaki çalışmaları birlikte yürütmek üzere Avrupa'nın diğer devletlerinden yardım istemişti. Sonrasında atılan adımlar tamamen Türkiye'nin çıkarlarına uygundu, bu aşamada İngiliz hükümetinin daha önce gerekli gördüğü malî yeniden yapılandırmadan feragat etmesi söz konusu olamazdı. O’Conor şahsen görevlilerin unvanının ajan sivile çevrilmesini tek bir şartla mümkün görmekteydi. Eğer daha önce sefirler tarafindan maliye delegeleri için belirlenen yetkilerin aynısına sahip olacaklarsa, unvanları değiştirilebilirdi. İngiliz sefirinin ifadesinden, Rumeli vilayetlerinin maliyesine dair takip etmekte oldukları maksada ulaşılmasına hizmet etmeyen bir çözüme yanaşmayacakları anlaşılmıştı.

O’Conor bu görüşmeden Dışişleri Bakanı Lansdowne'u haberdar ettiği gibi teklifi derhal Rus meslektaşı Zinovieff'e aktarmıştır. O'Conor Rus meslektaşını teklifi kabule yatkın bulmuştu. Zira Zinovieff daha önce birçok defa sadece Avusturya ve Rusya'nın Makedonya'da düzenin sağlanmasında başarılı olamayacağını, bundan dolayı diğer dört büyük devletin desteğinin istenmesi gerektiğini ifade etmişti. Dolayısıyla Zinovieff yeni ajan siviller atanmasını avantaj olarak görüyordu. Bununla birlikte Avusturyalı meslektaşının bu teklife ciddi şekilde karşı çıkacağını düşünmekteydi.

150 Bahr-i sefid Umum Filosu Kumandanı Hasan Rami Paşa'dan Mabeyn'e; BOA, Y.PRK.ASK, 235/12, Lef 9-10, 4 Aralık 1905.

151 BOA, Y.PRK.ASK, 234/80; 1 Aralık 1905. 
Beklendiği üzere konudan haberdar olan Baron Calice ajan sivil unvanıyla diğer dört devlet tarafından yeni görevliler tayin edilmesi fikrine itiraz etmişti. Hatta Dışişleri Bakanı Kont Gołuchowski aksi durumda ülkesinin Makedonya reformlarındaki görevini bırakıp, sahadan çekileceği tehdidinde bulunmuştu ${ }^{152}$.

II. Abdülhamid'in isteği üzerine aynı gün Fransız maslahatgüzar Boppe ile görüşen Selim Melhame Paşa, Dışişleri Bakanı Rouvier'ye iletilmek üzere bir mesaj getirmişti. Mesajda uzlaşmak istediğini bildiren II. Abdülhamid, Mürzsteg Programı'nın uygulanmasında Avusturya ve Rusya ile birlikte çalışmak üzere diğer büyük devletlerce ajan siviller görevlendirilmesini kabul ettiğini haber vermiştir. Bu ajan siviller de Avusturya ve Rusya tarafından atanmış halihazırdaki ajan sivillerle aynı görev ve yetkilere sahip olacaktı. Fransız Dışişleri Bakanı Rouvier'nin kendisine karşı olan iyi duygularından haberdar olduğunu söyleyen II. Abdülhamid, iki ülke ilişkilerinin devlet seviyesinde de iyi olduğuna inanıyordu. Mesajda Fransa Dışişleri Bakanından teklifini kabul ederse, diğer devletlere de tavsiye etmesini ve ilişkilerin geldiği düğümün çözümü için arabuluculuk yapmasını istemişti. Altı büyük devletin sahip olacakları ajan siviller ve Osmanlı Bankası'nın yapacağı organizasyon sayesinde reformların Makedonya'da uygulanabilmesi için büyük devletlerin bütün garantilere sahip olacağını ifade etmişti. II. Abdülhamid Makedonya'da şerefine zarar veren bir Maliye Komisyonunun kurulmasına izin vermeyeceğini belirterek, daha fazlasını yapmayı reddetmiştir ${ }^{153}$.

Osmanlı Devleti'nin artık tek ümidinin, Almanya'nın desteğini sağlamak olduğu anlaş1lıyor. Almanya sefiri ise bu konuda hükümetince yapılacak her türlü teşebbüsün diğer devletler karşısında fayda sağlamayacağını söylemiştir. Babıali’nin teklifinin Alman hükümetince kabul edilmesinin diğer devletler tarafından iyi karşılanmayacağına vurgu yapan Bieberstein'ın bu tutumu aslında, Prens Bülow'un daha önce Berlin Sefareti'ne verdiği “Almanya'nın beş devlete karşı ittihaz ettiği meslekten inhirâf edemeyeceği” cevabiyla paralellik arz ediyordu ${ }^{154}$. Bununla birlikte Osmanlı Devleti İstanbul'da sefirlerin gerçekleştirdiği toplantılarda aldıkları kararlardan Alman sefiri vasıtasıyla haberdar olmaya devam ediyordu.

II. Abdülhamid'in teklifini değerlendiren Dışişleri Bakanı Rouvier, sefirler tarafından hazırlanmış olan Nizamnamenin aynen korunması kaydıyla Fransa Hükümetinin bu fikre hemen uyum sağlayabileceğini bildirdiği Boppe'a, bunu diğer meslektaşlarına ifade etmesini emretmiştir. Mevcut şartlar altında daha önemlisinin Büyük Güçlerin aralarındaki ittifakı devam ettirmeleri olduğunu vurgulamasını ayrıca istemişti.

152 Boppe'tan Rouvier'ye, 30 Kasım 1905: Documents Diplomatiques Français (1871-1914), 2. Série (19011911), s. 238-239.

153 Ayni belge.

154 BOA, YEE, 50/79; BOA, Y.A.HUS, 496/5. Sadrazam Ferid Paşa’nın 2 Şevval 1323 (30 Kasım 1905) tarihli arz1. 
Bu arada Rouvier gizli kaydıyla paylaştı̆ğ bilgide, Babıali’ye hoş görünmek isteyen Paris sefareti maslahatgüzarı Nabi Bey'in Fransa'nın devletlerle olan uyumundan (Concert des Puissances) ayrılabileceği umudunu paylaştığına dair izlenimleri olduğunu ifade ederek, ilgili hükümetlerin tamamının onaylamadığı hiçbir öneriyi kabul etmeyeceklerini Babıali’ye yeniden bildirmesi için Boppe'a talimat vermişti ${ }^{155}$.

$\mathrm{Bu}$ dönemde büyük devletlerin İstanbul'daki sefirleri sürekli istişare halindeydiler. Daha önce de bahsedildiği üzere, bahriye nümayişi bu aşamada sefirlerin ortaklaşa aldıkları kararlara göre yönetiliyordu. Osmanlı Devleti ise bir taraftan yaptığı son teklifin büyük devletlerin başkentlerinde nasıl karşılandığını anlamaya çalışıyor, diğer taraftan ise İstanbul'daki sefirlerin faaliyetlerini yakından takip ediyordu. Anlaşıldığı kadarıyla İngiltere hükümeti bu teklifi görüşmek üzere gündeme almıştı. Benzer şekilde Roma'daki Osmanlı sefiri de konu hakkında İtalyan hükümeti nezdinde girişimlerini sürdürüyordu. Hariciye Nazırı Tevfik Paşa’nın Alman Sefiri Bieberstein'a teyit ettirdiğine göre sefirler bir araya gelerek Maliye Komisyonu konusunda devletler arasındaki uzlaşma ve birliğin korunmasını görüşmüşlerdi ${ }^{156}$.

Bieberstein ise Osmanlı Devleti'ni ikna çabalarına devam ediyordu. Tevfik Paşa'ya, Osmanlı Devleti Maliye Komisyonu hakkında sunulan nizamnameyi esastan kabul ederse, maddelerin tadiline dair isteklerinin diğer devletlerce kabul edilebileceğini haber vermiştir. Bunun için yapılacak tadil ve tashihlerin konunun aslından çok uzaklaşmadan hızlıca gerçekleştirilerek, resmen ve acilen sefaretlere gönderilmesini önermiştir. Bu gerçekleşirse sorunun çözümü hızlanacaktı. Kendisi de sefirlerin bu konuda yapacakları müzakerede Osmanlı Devleti lehine davranarak, önerileri meslektaşlarına kabul ettirme gayretinde olacaktı. Bieberstein'a göre dört devletin tayin edeceği memurlara verilecek unvan işin aslına pek etki etmeyeceğinden, sefirler bunu kabulde tereddüt göstermeyeceklerdir. Büyük devletler Nizamnamenin esasının korunmasına kesin olarak karar verdiklerinden mesele çok kapsamlı değişiklikler yapmaya müsait değildi ${ }^{157}$.

Osmanlı Devleti sorunun çözülmesi konusunda hem İstanbul'daki büyük devletlerin sefirleri nezdinde hem de başkentlerinde yoğun bir diplomatik faaliyet yürütüyordu. Diğer dört büyük devletin maliye delegeleri yerine Avusturya ve Rusya'nın ajan sivilleriyle aynı unvan, yetki ve haklara sahip görevliler tayin edilmesi teklifi her ne kadar Fransa, İngiltere, Rusya ve İtalya tarafindan kabul edilebilir bulunmuş olsa da Avusturya buna şiddetle karşı çıkmış, böyle bir ihtimalde müşterek filodan çekilme tehdidinde bulunmuştur. Rus sefir Zinovieff kişisel olarak unvan değişikliği konusuna itiraz etmemekle birlikte, Mürzsteg

155 Rouvier'den, Boppe'a, 1 Aralık 1905: Documents Diplomatiques Français (1871-1914), 2. Série (1901-1911), s. 245-246.

156 BOA, Y.A.HUS, 496/15, Lef 3: Hariciye Nazırı Tevfik Paşa'dan Sadaret'e, 4 Şevval 1323 (2 Aralık 1905).

157 BOA, Y.A.HUS, 496/15, Lef 3. 
Programı'na uygun bir şekilde Avusturya sefirini desteklemeyi sürdürmüştür. Aslında İngiltere ve Fransa sefirleri Osmanlı Devleti'nin yaptığı son teklif konusunda olumlu bir bakış açısına sahipken büyük devletler arasındaki ittifakın bozulmaması adına konuşmaktan kaçınmışlardır ${ }^{158}$. Devletlerin söz konusu tutumu karşısında Osmanlı Devleti için artık Bieberstein’ın tavsiyesine uymaktan başka bir seçenek kalmamış gibiydi.

$\mathrm{Bu}$ arada gazetelerde konu hakkında herhangi bir haber yapılmasinı istemeyen II. Abdülhamid, gerekli tedbirlerin alınması talimatını da vermişti. İç kamuoyunun manipüle edilerek bir heyecan oluşmasının önüne geçmeyi amaçladığı düşünülebilecek bu kararın yanında, konu hakkında İstanbul'dan Avrupa'daki basın organlarına telgraf çeken yabancı kişilerin kimliğinin ve amacının anlaşılmasını da istemişti ${ }^{159}$.

\section{Osmanlı Devleti'nin Maliye Komisyonu Kurulması Teklifini Kabul Etmesi}

Bahriye nümayişi daha önce belirlenen program uyarınca devam etmekteydi. Yukarıda bahsedildiği üzere, önce Midilli’yi işgal eden müşterek fillo tanınan süre içinde Osmanlı Devleti'nden olumlu cevap alamayınca Limni’ye doğru harekete geçmişti. $\mathrm{Bu}$ arada beklenmedik bir gelişme yaşanmış, Babıali 5 Aralık 1905 gecesi Avusturya sefíri Baron Calice'e bir nota göndererek, maliye delegeleri atanmasını ve Maliye Komisyonu'nun çalışma usullerini düzenlemek üzere hazırlanmış Nizamnameyi, bazı tadilat yapılması şartıyla kabul etmiştir.

Osmanlı Devleti'nin bu adımının arka planını aynı günün tarihini taşıyan bir belgeden okumak mümkündür. Muteber bir ecnebinin ${ }^{160}$ verdiği habere göre, bir olay çıkmasını istemeyen, telaş içindeki sefirler, bu gece donanmayı Midilli' den daha ileri götürmeyeceklerdi. En son yapılan Meclis-i Vükela müzakerelerine Abdurrahman Paşa katılmamış, Maarif Nazırı karara muhalefet etmiş ve Serasker Paşa ise mazbatayı imzalamamıştır. Bu nedenle henüz vakit olduğunu düşünen Sadrazam Ferid Paşa, ileride herhangi bir tartışmaya mahal kalmaması için konunun bir kez daha Meclis-i Vükela'da etraflıca müzakere edilmesini ve bahsi geçen ecnebinin tavsiyesi uyarınca, Osmanlı Devleti’nin bakış açısını izah etmek amacıyla eski sadrazam Said Paşa'nın İngiltere sefiriyle görüşmesi önerilerini II. Abdülhamid'e arz etmişti.

II. Abdülhamid'in isteği üzerine Sadrazam Ferid Paşa ile Hariciye Nazırı Tevfik Paşa bir durum değerlendirmesinde bulundular. Tevfik Paşa iki görüşme yapmıştı. Bunlardan birinde Almanya Sefiri Baron Marschall von Bieberstein sefirlerin daha önceki ifadelerini

158 Boppe’tan Rouvier’ye, 2 Aralık 1905: Documents Diplomatiques Français (1871-1914), 2. Série (1901-1911), s. 246-247.

159 BOA, Y.A.HUS, 496/31.

160 İzzet Holo Paşa bu kişinin o sırada Düyûn-1 Umûmiye İdare Meclisi azasından Adam Block olduğunu belirterek, konuyu belgedeki şekliyle aktarıyor. Arap İzzet Holo Paşa’nın Günlükleri, I, s. 435-435. 
tekrarladıktan sonra, müşterek donanmanın hareketi o gece için ertelenmiş olsa da ertesi güne kadar bir cevap verilmezse Bozcaada ve Limni'nin işgal edilmesinin kesin olduğunu ve devletlerin tekliflerini artırma ihtimali bulunduğunu ifade etmişti. Osmanlı hükümetinin lehine bazı tadilat yapılması ve uygulanan baskıya son verilerek, müzakerelerin devam ettirilmesi için Rusya Sefareti Baştercümanından Rusya'nın aracılığı aranıldı. Baştercüman ise Bozcaada ve Limni'nin işgalinin daha önce karar verilmiş bir program kapsamında olduğu, Osmanlı hükümetinin maksat ve hedefinin belli olmaması gibi gerekçeler ileri sürmüştü. Diğer taraftan Rusya'da birtakım karışıklıklar söz konusu olduğundan, şartların bu konuda Rusya'dan yardımın teminine uygun olmadığı değerlendirildi. Bu ikisi dışında diğer devletlerin meylettirilmesi de mümkün görülmemişti.

Rumeli'deki üç vilayetin malî işleri konusunda en uygun çözümün daha önce Babiali'nin hazırladığı Talimatname olduğuna inanan Ferid Paşa, bu talimatnamenin sefirlere tebliğ edildiğinin ve Osmanlı saltanatının şeref ve vakarına aykırı bulunan baskılara son verilmesi için gerekli adımların atıldığının altını çizmiştir. Meselenin başladığı andan itibaren kendisi Osmanlı Devleti’nin menfaatinin muhafazası ve müdafaası için elinden gelen her türlü çabayı göstermişti. Bundan doğan her türlü maddi ve manevi tesir dayanılamaz bir seviyeye varmasına rağmen, sadakatinin ve bağlılığının bir gereği olarak yapılması gereken ne varsa yapmaktan bundan önce olduğu gibi sonra da geri durmayacakt ${ }^{161}$. Ferid Paşa'nın Almanya sefirinin tutumu ve Rusya'nın durumuna yönelik izahı, artık baskılara dayanacak şahsi gücünün kalmadığını açıkça ifade etmesi ve belki de daha önemli olarak bahriye nümayişinin Limni ve Bozcaada'ya doğru ilerlemesinin kesin olduğunu söylemesi II. Abdülhamid'in ikna olmasını ve Osmanlı Devleti’nin bazı tadilat kapsamında yapılan teklifleri kabul etmesini sağlamıştı.

İzzet Holo Paşa II. Abdülhamid'in büyük devletlerin taleplerini kabul etmesini farklı bir şekilde değerlendirmiştir. Buna geçmeden önce Osmanlı Devlet adamları arasında Maliye Komisyonu konusunda bir fikir birliği olmadığının altı çizilmelidir. Fransız ve İngiliz diplomatik yazışmalarında da devlet adamları arasında Büyük Güçlerin teklifleri karşısında kararlı bir duruşu veya uzlaşmayı savunan iki grubun varlığına atıf yapılmaktadır. Daha önce bahsedildiği üzere, devletlerin tavrını ayak patırtıs1 ${ }^{162}$ olarak niteleyen İzzet Holo Paşa, baskılar karşısında son noktaya kadar direnilmesi gerektiğini savunuyordu. Savaşla kaybedilmeyen Rumeli topraklarının, eğer bölge yabancı memurların malî kontrolü altına girerse hiçbir şey yapılmadan düşmana teslim edilmiş olacağı görüşündeydi. Günlüklerine bakılırsa İzzet Holo Paşa konu hakkında oldukça kesin ve keskin olan görüşlerini ısrarla ve zaman zaman padişahın azarlamalarına muhatap olacak derecede bir açıklıkla ifade etmişti.

İzzet Holo Paşa, baskılar karşısında birçok defa talepleri kabul etmeye meyletmiş olan II. Abdülhamid'i, kimi zaman ikna kimi zaman tehdit ederek kararından vazgeçirdiğini iddia

161 BAO, Y.A.HUS, 496/29, 7 Şevval 1323 (5 Aralık 1905); Kırmızı, Avlonyalı Ferid Paşa, s. 264-265.

162 Arap İzzet Holo Paşa'nın Günlükleri, I, s. 423. 
etmektedir. Devam eden baskılar karşısında II. Abdülhamid' in direnci bir süre sonra düşmüştür. Bir süre sonra devletlerin tekliflerini kabul etmeye karar vererek İzzet Holo Paşa’ya, "bundan ziyâde sebât beni mehâlike ilkā eder ve düvel-i müttehide donanmaları İstanbul Limanı'na gelip Zengibar Hâkimi hakkında edilen muâmele vechile sarayımı topa tutarlar. Binâenaleyh, teklifât-1 vâk1'ayı kabûlden başka çare yoktur. Sadrazam[a] benim şu irâdemi teblî̆g ve hemen Encümen-i Vükelâ'yı davetle bu yolda karâr arz ettirmesini selâmla beraber ihtâr ediniz" şeklinde emir verir ${ }^{163}$. İzzet Holo Paşa bu durumdan doğacak vahameti ifade etmesine rağmen padişahı vazgeçiremediğini, bunun üzerine emredildiği üzere Sadrazam'a gerekli tebligatta bulunduğunu bildirmektedir. Sadrazam ise 2 Aralık (19 Teşrinisani) Cumartesi Babıli'de Encümen-i Vükela'yı toplamıştır. Adliye Nazırı Abdurrahman Paşa mükerrer emirlere rağmen hasta olduğu bahanesiyle toplantıya katılmamış, yapılan müzakerelerde Padişahın iradesine uygun bir karar alınamamıştı.

Encümende konu hakkında büyük devletler nezdindeki Osmanlı sefirlerinden gelen haberler değerlendirilmiş, bu ülkelere yapılan müracaatlardan henüz tam bir cevap alınamadığı ifade edilmişti. İzzet Holo Paşa bu aşamada İngiltere, Fransa ve İtalya'nın, Osmanlı Devleti'nin detaylarından yukarıda bahsedilen maliye delegeleri yerine ajan siviller atanması teklifine sıcak baktıkları, dolayısıyla malî kontrol yerine Rumeli Genel Müfettişi nezdinde bulunan Avusturyalı ve Rus ajan siviller gibi iç işlerine müdahale etmeyecek memurlar görevlendirilmesini kabul edecekleri görüşündeydi. Her ne kadar konudan haberdar olsa da bunu yeniden II. Abdülhamid'e hatırlatması üzerine, ilginç bir tepki görmüştü. Padişah, "Teklîfât-1 vâkı'aya cihet-i askeriyenin isrâfâtı ve haydutlar gibi mal sandıklarına tehâcüm ederek para nehb ü gāret yolundaki harekâtı sebebiyet vermiş idiğünden şimdi israr ve inada mahal yoktur. Eğer irâdâtıma muhâlif müdafaa ve taallülat devam edecek olur ise benim medhâlim olmadığını ve muhâvelatın anâsır ve vükelâ-yı devlet taraflarından ikā olunmakta bulunduğunu sûret-i hafiyyede süferâya ihbâr ederim" demişti ${ }^{164}$. İzzet Holo Paşa buna rağmen padişahı vazgeçirmeye çalıştığını ancak başarılı olamadığını söylemektedir.

Yine İzzet Holo Paşa'nın günlüklerinde yazdığına göre, verilen emir üzerine Sadrazam Ferid Paşa ertesi gün Meclis-i Vükela’yı tekrar toplamış, gerekli kararı aldırmak için çabalamıştır. Manzara bir önceki toplantıdan pek de farklı değildi. Abdurrahman Paşa yine toplantıya katılmamış, Maarif Nazırı Haşim Paşa da daha önceki ret kararının savunulması gerektiği görüşünü bildirmişti. Serasker ise mazbatayı mühürlemekten kaçınmıştı. 4 Aralık'ta II. Abdülhamid'in huzuruna çağrılan İzzet Holo Paşa'dan, son Meclis-i Vükela mazbatasını mütalaa etmesi istenmiştir. İkinci katip, yaptığı değerlendirmede mazbatanın

163 Arap İzet Holo Paşa'nın Günlükleri, I, s. 432.

164 İzzet Holo Paşa günlügüne çok ağır bir ifadeyle böyle bir davranışın hiçbir Müslüman tarafından gerçekleştirilemeyeceğini yazmıştır. Arap İzet Holo Paşa ’nın Günlükleri, I, s. 433. 
onaylanmasının Osmanlı Devleti’nin bekasına son verilmesi demek olacağını açıkça ifade eder. Bu değerlendirme karşısında II. Abdülhamid daha öncekine yakın bir cevap vererek, devletlerin düşmanlığını kendisine çekemeyeceğini belirtir. Buna karşılık İzzet Holo Paşa da sefirlerin padişaha karşı hiçbir şey yapamayacaklarını, müttefik filonun Çanakkale Boğazı'nı geçerek Şark ve Boğazlar Meselesini açmak istemeyeceklerini ifade eder ${ }^{165}$. II. Abdülhamid'in mazbatayı tasdik etmesi bu görüşmeden sonra gerçekleşmişti.

Ferid Paşa'nın muteber bir ecnebi deyip ismini vermediği Adam Block tam da İzzet Holo Paşa II. Abdülhamid'in huzurundan çıktığı sırada Yıldız Sarayı'na gelmişti. İzzet Paşa'ya göre her ne kadar Block'un getirdiği haberler Sadrazam Ferid Paşa'nın takip ettiği politikaya uygun değilse de bu türden önemli bir bilgiyi saklamaktan korkmuş ve bu meseleden doğacak töhmeti padişaha atmak isterken kendisi yüklenmiş olacağından, durumu kendisine bildirmek zorunda kalmıştı. İzzet Holo Paşa bir kez daha II. Abdülhamid'i kararından vazgeçirmek niyetiyle harekete geçer. Kendisine sadrazamın maruzatı arz edilince II. Abdülhamid, başına bir iş getirmek isteyen İngiltere sefaretinin bu haberi kasten yolladığını ve bu tertibin arkasında Said Paşa'nın olduğunu söyleyip, böyle melanetlerle iğfal edilemeyeceği karşılığını vermiştir. Bu şekilde II. Abdülhamid tarafından tasdik olunan mazbata Babıali’ye iade edilmişti. Aynı gece Sadrazam ve Hariciye nazırları sefirlere yazılacak cevap üzerinde çalışmaya başlamışlardı. Bu sırada Abdülhamid'in evhamı artmış ve sefirlere gerekli tebligatın derhal yapılmasını istemişti. İzzet Holo Paşa kabul cevabını almaları üzerine sefirlerin kendi aralarında yaptıkları toplantının da kendi aleyhinde olduğundan şüphelenen II. Abdülhamid'in bu nedenle gece vakti Necib Melhame'yi çağırarak İngiltere sefaretine gönderdiğini ve aldığı cevapla işin sona erdiğini anlayarak rahatladığını anlatmaktadır ${ }^{166}$.

Sefirler krizin bu kadar hızlı çözüme ulaşacağını beklemiyorlardı. Baron Calice'in ilk izlenimi Nizamnamede çeşitli tadilat öngören Babıali’den gelen metnin kabul edilebilir olduğuydu. Boppe'a göre Sultanın boyun eğmesi (la soumission du Sultan) şüphesiz uluslararası filonun Limni’ye ulaştığı haberini almasından kaynaklanıyordu ${ }^{167}$.

165 İzzet Holo Paşa konuşmanın devamında “(...) Lakin cülûs-ı hümâyûnunuzda beri türlü mihen ve mezâlime giriftâr olan ve âbâ vü ecdâd kanlartyla fetholunan memâlikin çoğunu işte bu makūle hayalât ve tevehhümât eseri olarak zayi eden milletin heyecanından ihtiraz etmek ve bir Kanûn-ı Esâsi ilân ettirilmesi için elyevm komşumuz olan Rusya'da hüküm-fermâ olan ihtilalât-ı dahiliyeyi feramuş eylemek menfaât-i şahanenize muhaliftir" dediğini yazmaktadır (Arap İzzet Holo Paşa'nın Günlükleri, I, s. 434). İzzet Holo Paşa'nın II. Abdülhamid ile konuşmalarında söylediğinden bahsettiği bu ve benzeri ağır ifadeleri gerçekten padişaha söylemiş mi yoksa aklından geçirerek, günlüklerine bu şekilde yazmış mı olduğu üzerinde düşünülmesi gereken önemli bir konudur.

166 Arap İzet Holo Paşa'nın Günlükleri, I, s. 435.

167 Boppe'tan Rouvier’ye, 5 Aralık 1905: Documents Diplomatiques Français (1871-1914), 2. Série (1901-1911), s. 256. 
Gerçekten de uluslararası filo bahriye nümayişine devam ederek, Limni Adası'na asker çıkarmıştı (6 Aralık 1905) ${ }^{168}$. Teklifleri Osmanlı Devleti tarafından resmen kabul edilmesine rağmen Limni Adası'nın işgaline anlam veremeyen II. Abdülhamid, biraz endişe duymuştu. Endişesi müşterek fillonun Boğazlara yaklaşmış olmasından kaynaklanıyordu. Bu nedenle söz konusu filonun daha ileri gitmesine izin verilmemesi için gerekli önlemlerin alınmasını istemişti ${ }^{169}$. Ayrıca sefirlerin henüz bildirmedikleri başka birtakım isteklerinin olup olmadığını sormuştu ${ }^{170}$.

II. Abdülhamid Rumeli'deki üç vilayet hakkında devletler tarafından verilen karar dışında, İstanbul'daki sefirlerin yapacakları her türlü teklifin hiçbir şekilde kabul edilmemesini emretmişti. $\mathrm{Bu}$ sırada toplantı halinde bulunan sefirler, hükümetlerinin vereceği cevabı bekliyorlardı. Gelişmeleri Osmanlı Hariciye Nezareti'ne aktarmayı sürdüren Alman Sefiri henüz bir karar alınmadığını, sadece Limni'de bulunan işgal filosunun başındaki amirale statükonun devamı talimatı verildiğini; görüşmelere ertesi gün de devam edileceğini ifade etmişti. Babıali teklif ettiği tadilat önerisinin kabul edilmesinde Almanya sefirinin lehteki desteğine güveniyordu ${ }^{171}$.

Böylece, büyük devletler 15 Kasım tarihinde verdikleri notada, tekliflerinin kabul edilmemesi durumunda zorlayıcı birtakım uygulamalara başvurulacaklarına dair tehditlerini 26 Kasım'da Midilli, 6 Aralık’ta da Limni’nin işgaliyle uygulamaya koymuşlardı. Osmanlı hükümeti uzun süredir kendisine kabul ettirilmeye çalışılan şartları resmen kabul etmiş olsa da bahriye nümayişi planlandığı şekilde devam ettirilmiştir. Bununla birlikte 5 Aralık sonrasında, Maliye Komisyonu'nun çalışma usulleri, görev ve yetkilerinin belirlendiği Nizamname maddeleri üzerinde Osmanlı hükümeti ile büyük devletlerin sefirleri arasında oldukça detaylı bir müzakere süreci ve nota teatisi başlamıştı. Osmanlı Devleti, etraflıca incelenerek Meclis-i Vükela'da müzakere edilen Nizamnamenin, bağımsızlığına, hukukuna ve mevcut antlaşmalara aykırı gördüğü bazı maddelerin ve cümlelerin tadil edilmesi için yoğun bir çaba sarf etmiştir ${ }^{172}$.

168 Limni’ye çıkan askerler; telgrafhaneye memur göndererek, şifreli yazışmayı yasaklamışlardır. Akdeniz Boğaz Muhafızlığı müşterek filonun Boğaza yönelmeleri ve taarruzda bulunmaları halinde ne şekilde hareket edilmesi gerekeceğini sormuştur. Müşterek donanmanın, resmî cevabın sefirlere tebliğinden önce Midilli' den harekete geçip, Limni’ye geldiği anlaşılmıştır: BOA, YEE, 50/80; BOA, Y.PRK.UM, 77/87, Lef 5.

169 BOA, YEE, 49/88, Serkatib Tahsin imzalı 8 Şevval 1323 (6 Aralık 1905) tarihli irade.

170 Sadrazam Ferid Paşa'ya göre Limni’nin işgalinden dolayı bir endişe ve tereddüde gerek yoktur. Babıali tarafından küçük bir telaş gösterilmesi durumunda irade gereği tebliğ olunan cevabın etkisi azalacaktır, devletlerin tutumunun şiddetlenmesine sebep olacaktır. Sefirlerin konu hakkında bildirmedikleri bir talepleri kalmamıştı. Padişahın bu anlamda müsterih olması için derinleştirilen tahkikat bir saate kadar arz edilecekti. BOA, YEE, 50/80.

171 Bu arada Alman Sefiri “dostluğu icabınca elden gelen gayreti sarfta kusur etmediği”ni belirtiyordu. Büyük devletlerle birlikte hareket etmek zorunda kalan Almanya, önemli ticari ve ekonomik çıkarlarının bulunduğu Osmanlı Devleti’ni bu tavrı ile gücendirdiğinin farkında olarak, telafi peşindedir.

Sadaretin, konunun devamında, "ihdas-1 gavailden ictinab etmek isteyen bazı Avrupa devletlerinin 1srarı üzerine tadilat ve teklifat-1 vakıamızın mazhar-1 hüsn-i kabul olması kaviyyen memul olmakla” ifadesi Almanya'dan beklenen yardımının boyutunu gösteriyor: BOA, YEE, 50/83, 7 Aralık 1905.

172 Osmanlı Devleti'nin istediği tadilatın detaylı için: BOA, Y.A.HUS, 496/68, Lef 2, Sadrazam Ferid Paşa'nın 12 Şevval 1323 (10 Aralık 1905) tarihli arzı. 


\section{Bahriye Nümayişinin Sona Ermesi}

Bahriye nümayişi ve işgallerin bir an önce sona erdirilmesini isteyen II. Abdülhamid, Nizamnamede yapılacak tadilat konusunda hızl hareket edilmesini istiyordu. Nitekim 7 Aralık’ta Osmanlı Hariciyesi üzerinde yapılmasını talep ettiği değişikliklerin olduğu nüshayı Avusturya sefiri Baron Calice'e göndermişti ${ }^{173}$. Sefirler bahriye nümayişinin ve bu kapsamda gerçekleştirilen işgallerin sona erdirilmesi talebine ise Nizamname dahil olmak üzere daha önce Babıali'ye sunulan tüm şartların kabul edildiğinin bildirilmesiyle son vereceklerine dair bir notayla karşıllı vermişlerdi ${ }^{174}$.

Osmanlı Devleti’nin tashih ve tadil talep ettiği on noktanın görüşüldüğü sefirler toplantısında bazı hususlar yeniden düzenlenmiş, bazı teklifler ise tamamen reddedilmişti ${ }^{175}$. Mesela İngiliz sefiri O'Conor Nizamname yerine önerilen talimatlar sözüne ve Maliye Komisyonu'nun süresinin 2 yıl ile sınırlandırılmasına karşı çıkmıştı176.

Osmanlı Devleti Nizamname üzerindeki son tashihlerini 14 Aralık'taki notasıyla sefirlerle paylaşmıştı. Bu sırada Osmanlı Devleti tarafından daha önce de teklif olunan, Makedonya'daki reformların finansmanında kullanılmak üzere gümrük vergilerinde \%3 artışa gidilmesi bir kez daha gündeme gelmişti ${ }^{177}$. Sefirler karmaşık birtakım çıkarları ilgilendiren bu konuya cevap vermeye yetkili olmadıklarını, konu hakkında hükümetlerine başvuracaklarını söylemişlerdi ${ }^{178}$. Sunulan bütün isteklerin Osmanlı hükümeti tarafından kabul edildiğini söyleyen Fransa maslahatgüzarı Boppe’a göre büyük devletler tüm taleplerini elde etmişlerdi. Bunlar; Maliye Komisyonu'nun kurulması, ajan sivillerin görev sürelerinin uzatılması, Rumeli Genel Müfettişinin görev süresinin uzatılarak yetkilerinin artırılması, Jandarma reformuyla görevli General Giorgis'in ve bu işte çalışan yabancı subayların sözleşmelerinin aynı süre için yenilenmesi ve görüşmeler neticesinde üzerinde uzlaşılan Nizamname idi. Bahriye nümayişi artık amacına ulaşmıştı. Uluslararası filonun Midilli ve Limni'de daha fazla tutulması bir otorite kaybına yol açabilirdi ${ }^{179}$.

173 BOA, Y.A.HUS, 496/47, Lef 5.

174 BOA, Y.A.HUS, 496/47, Lef 4.

175 Boppe'tan Rouvier'ye, 12 Aralı 1905: Documents Diplomatiques Français (1871-1914), 2. Série (19011911), s. 285-286.

176 Further Correspondence Respecting the Affairs of South-eastern Europe, nr. 158, s. 114.

177 BOA, Y.A.HUS, 497/1.

178 Osmanlı Devleti'nin Ocak 1905’te gündeme getirdiği \%3 gümrük artışı konusunda en ciddi itirazı gösteren İngiltere'ydi. Fransızlar Ekim 1905'ten itibaren daha olumlu bit tavır içindeydiler (Rouvier'den Londra'daki Fransa sefiri Geoffray'a, 17 Kasım 1905: Documents Diplomatiques Français (1871-1914), 2. Série (19011911), s. 191). Bu konuda diğer devletlerin pozisyonu ve özellikle İngiltere'nin itirazları hakkında bkz. Bayraktar, Makedonya Sorunu, s. 94-101.

179 Boppe'tan Rouvier'ye, 16 Aralık 1905: Documents Diplomatiques Français (1871-1914), 2. Série (19011911), s. 318. 
Sadrazam Ferid Paşa da istekleri kabul edilen devletlerin bahriye nümayişine son vererek, işgal ettikleri adaları tahliye etmelerinin an meselesi olduğu, programda olmasına rağmen filonun Bozcaada'ya yönelmemesinin buna işaret ettiği yorumunu yapmıştı. İngiliz sefirinin devam eden bazı itirazlarının ise Osmanlı Devleti’nin gümrük vergilerine \%3 zam yapılması talebinden kaynaklandığını düşünmekteydi ${ }^{180}$.

Son olarak 16 Aralık'ta Baron Calice'in konağında toplanan sefirler, Osmanlı Devleti'nin Nizamnameye dair tekliflerini değerlendirerek bazı maddelerin ifade şekillerinde değişiklikler yapmışlardır. Akabinde sefirlerin hazırladığı, Babıali’nin Büyük Güçlerin isteklerini yerine getirmiş bulunmasıyla uygulanmakta olan tedbirlere (mesures) son verildiğini ilan eden nota Osmanlı hariciyesine ulaştırılmıştır. Aynı gece Baron Calice, bahriye nümayişini gerçekleştiren müşterek filonun kumandanı Amiral Rippen'i durumdan haberdar etmişti ${ }^{181}$. Böylece beş büyük devletin ortak filosunun 22 Kasım'da Pire Limanı'nda toplanarak üç gün sonra başladığı, 26 Kasım'da Midilli ve 6 Aralık'ta Limni'nin işgal edildiği bahriye nümayişi 16 Aralık itibariyle sona ermiştir. Gerçekleştiren devletler bakımından nümayiş amacına ulaşmış, Osmanlı Devleti Makedonya'daki malî kontrol mekanizmasının kurulmasını kabul etmişti.

\section{Sonuç}

Büyük Güçlerin uzun bir süre Avusturya-Rusya ikilisinin yönlendirmesine bıraktıkları Osmanlı Makedonya'sında yapılacak reformların içeriği ve uygulama yöntemleri, özellikle İngiltere'de, baskı gruplarının yönlendirmelerinin de etkisiyle, 1904 yılı itibariyle yoğun bir şekilde sorgulanmaya başlanmıştı. Avusturya-Rusya reform projelerinin bu gruplar tarafından en çok eleştirilen yönü muhafazakar bir içeriğe sahip olmasıydı. İngiltere'nin savunduğu yeni bakış açısı ise, başarısız olan bu muhafazakar reform projelerinin yerine daha radikal uygulamaların hayata geçirilmesi gerektiğini söylüyordu. Uygulanan reformların başarısına etki ettiği tüm taraflarca kabul edilen bir husus bölgenin malî durumuydu. Avusturya ve Rusya tarafından bölgenin malî işleyişinin iyileştirilmesi adına ortaya atılan teklif, yeniden Makedonya'daki reformların hazırlanma sürecine dahil olabilmeleri adına diğer devletlerce bir firsat olarak görülerek, çok taraflı bir finansal kontrol mekanizması önerisi olarak Osmanlı Devleti'ne yapılan bir teklife dönüştürüldü. Osmanlı Devleti Rumeli'deki üç vilayetinde uygulanmak istenilen bu malî denetim mekanizmasına en başından itibaren karşı çıkmış ve bu konuda uzun süre güçlü bir duruş sergilemiştir. Osmanlı devlet adamlarının buradaki temel argümanları uygulanmak istenilen sistemin bağımsızlık, bütünlük ve hükümranlık haklarına zarar vereceği, ayrıca bütün bunları garanti eden başta Berlin Antlaşması olmak üzere devletin taraf olduğu hiçbir antlaşmaya uymadığıydı.

180 BOA, Y.A.HUS, 497/12.

181 Boppe'tan Rouvier'e, 16 Aralık 1905: Documents Diplomatiques Français (1871-1914), 2. Série (1901-1911), s. 324-325; BOA, YEE, 50/85. 
Teorik çerçevesi Soğuk Savaş döneminde Alexander L. George tarafından çizilmiş zorlayıcı diplomasinin temelinde tehdit ve sınırlı güç kullanımı yer almaktadır. Bu iki araç rakibin ikna edilmesinde, geri adım attırılmasında kullanılmaktadır. Esas olan tehdit olup, karşı tarafta bir korku, olayın daha büyük sonuçları olacağına dair bir endişe oluşturmak hedeflenmektedir. Başka bir ifadeyle, zorlayıcı diplomaside esas olan gücün kullanılması değil, kullanılabileceğinin gösterilmesi suretiyle oluşturulan tehditten yararlanarak, karşı tarafın ikna edilmesi önemlidir. George zorlayıcı diplomasinin devlet yönetiminde aslında çok uzun zamandır başvurulan bir strateji olduğuna dikkat çekmiştir.

Büyük Güçlerin Mayıs 1905'te Makedonya için bir Maliye Komisyonu kurularak, bölgenin malî işlerinin bu komisyonun kontrolüne verilmesi teklifine karşı çıkan Osmanlı Devleti'nin ikna edilmesinde takip edilen yöntem esas itibariyle bir zorlayıcı diplomasidir. Büyük Güçlerin bu süreçteki uygulamaları zorlayıcı diplomasinin George ve takipçileri tarafından ortaya konulan neredeyse bütün özelliklerini taşımaktadır. Kronolojik olarak sıralanacak olursa tekliflerini verdileri notalarla iletmişler, notalarda isteklerin kabul edilmemesi durumunda zorlayıcı birtakım tedbirlere başvuracaklarını ifade etmişlerdi. Nitekim Osmanlı Devleti'nin kararlı duruşu karşısında bahsettikleri tedbir olarak bir bahriye nümayişi yapmaya karar vermişlerdi. Diğer taraftan bahriye nümayişinin gündeme geldiği Ekim 1905 sonundan itibaren diplomatik kanalların kullanılması da devam etmişti. Bu da zorlayıcı diplomasinin önemli bir bileşenidir. Zira zorlayıcı diplomasi esas itibariyle askerî değil diplomatik bir yöntemdir. Bu yüzden rakip üzerinde baskı kurmak için diplomatik enstrümanları kullanmaktadır. Verdikleri notalarda malî kontrol mekanizmasının kabul edilmemesi halinde bazı elim sonuçların doğabileceği tehditlerine rağmen Osmanlı Devleti'ni ikna edemeyen Büyük Güçler, daha somut bir tehdit olarak bahriye nümayişi yapılmasını gündeme getirmişlerdi. Bu tehdidin etkisi sürecin oldukça somutlaştığı 26 Kasım 1905 'te beş devletin gemilerinden oluşan uluslararası filo Pire Limanı'nda toplandığında görülmüş, Osmanlı hükümeti istenilen adımı atmıştı.

Osmanlı Devleti ise maruz kaldığ 1 diplomatik baskıyla kabul ettirilmeye çalışılan teklifin içeriğinin, tarafı olduğu başta Berlin Antlaşması olmak üzere çeşitli siyasî ve ekonomik antlaşmalara uygun olmadığına inanıyordu. Bu nedenle kendisini haklı görmekte, bu da diplomatik pozisyonuna olumlu bir katkı sağlamaktaydı. Asıl güvendiği husus dönemin uluslararası sistemi ve devletlerarasındaki ilişkilerdeki dengeydi. Kabule zorlandığı malî kontrol konusunda bir yaptırıma maruz kalmasının dönemin Büyük Güçleri arasında tam bir uzlaşma sağlanmasına bağlı olduğunu düşünen Osmanlı Devleti, diplomatik yazışmalardaki bazı ifadelerden anlaşıldığı üzere devletlerden birini veya birkaçını kazanarak, bu uzlaşmanın gerçekleşmesini önlemeye çalışmıştı. Büyük Devletlerden Almanya en başından itibaren, en azından bahriye nümayişine sıcak bakmadığını hissettirmişti. Bu diğer devletler açısından uygulanmak istenilen baskıyı zora sokan bir tavır olmakla birlikte, Almanya yine de dönemin 
uluslararası ilişkiler denkleminde önemli bir belirleyici olan uyumdan (concert) kopmamak adına çok sert bir itirazda bulunmak yerine diplomatik bir çözümü sonuna kadar zorlamış ve üstlendiği arabuluculuk rolünü de en son noktaya kadar sürdürmüştü.

Osmanlı Devleti tüm çabalarına rağmen kendisini destekleyebilecek ikinci bir devlet bulamamıştır. Diplomatik yazışmalardan anlaşıldığı kadarıyla bir ara Fransa ve Rusya gündeme gelmiş ancak bir sonuç elde edilememişti. Maliye Komisyonu teklifine karşı sağlam hukukî ve siyasî argümanlar ortaya koymasına rağmen, uluslararası hukuk bu dönemde Osmanlı Devleti için güçlü bir koruma sağlayamamıştı. Esasında uluslararası hukuk bu dönemde bir yönüyle Büyük Güçlerin kendi aralarındaki ilişkileri düzenleme ve birbirleriyle olan muamelelerinde bir belirleyici görevi icra ettiği için, Osmanlı Devleti'nin başvurduğu bir savunma aracı olarak söylemden öte bir etkisi olmamıştı.

Yoğun baskılar ve tehditlere rağmen Osmanlı Devleti'nin süreci uzatmasının da bir anlamı ve pratik bir yönü bulunmaktaydı. Bu yaklaşımın temelinde öncelikle devletlerin kendi aralarındaki ittifakı bozmak, ayrıca pazarlık süreci de uzadığı için hukukuna ve bağımsızlığına aykırı bulduğu ilgili maddeleri, şartları olabildiğince yumuşatmak için uygun bir ortam sağlamak yer alıyordu. Her ne kadar bazı araştırmacılar bu tavrı, işlerin son ana kadar ertelenmesi ve çaresizlik içindeki devletin ciddi yaptırımlara katlanmak zorunda kalması şeklinde basite indirgeyerek değerlendiriyorlar ise de en azından Makedonya'da kurulmak istenilen Maliye Komisyonu konusunda 1905 yılındaki gelişmeler Osmanlı hariciyesi ve merkezdeki karar alma mekanizmalarının çok yönlü olarak, yoğun bir çalışma içinde olduklarını göstermektedir. Unutmamak gerekir ki dönemin dünyasını sömürgeleştirmiş ülkelerin tamamına karşı, bağlayıcı bir uluslararası hukuk ve düzenleyici uluslararası mekanizmalar olmadan yürütülen bir mücadelede, askerî ve ekonomik olarak ciddi bir çöküş içinde bulunan Osmanlı Devleti bakımından kullanılabilecek çok fazla yöntem ve seçenek bulunmamaktaydı. Bu nedenle Osmanlı devletinin karar alma mekanizmalarınca, yukarıda makalenin ilgili bölümünde değerlendirilmiş olan bir yabancının mütalaasında ortaya koyduğu yaklaşım benimsenmişe benziyor. Büyük Devletlerin herhangi bir hukuka dayanmayan teklifleri karşısında sürecin olabildiğince uzatılması, mukavemet gösterilmesi, sonraki olası teklifler açısından caydırıcı olabilirdi. Dolayısıyla devlet süreci olabildiğince uzatmaya çalışmıştır.

Zorlayıcı diplomasinin izlerini fazlasıyla taşıyan 1905'teki Makedonya örneğinden hareketle, 19. yüzyılın ikinci yarısından itibaren uluslararası ilişkilerde artan kutuplaşma ve gerilimin bir sonucu olarak daha büyük çatışmalardan kaçınmak adına giderek önem verilip dikkate alınan Avrupa uyumunun toplu olarak yapılan bir zorlayıcı diplomasi girişiminde bir belirleyici olarak dikkate alınması gerektiği söylenmelidir. Bu uyum takip edilen strateji üzerinde hem süre bakımından hem de başarı oranı bakımından önemli bir etkiye sahiptir. 
Netice itibariyle, Makedonya'da kurulmak istenilen Maliye Komisyonu'na karşı çıkan Osmanlı Devleti'nin ikna edilmesinde dönemin Büyük Güçleri tarafından uygulanan strateji zorlayıcı diplomasinin erken bir örneğidir. Bununla birlikte konunun birtakım diplomatik strateji ve yöntemler takip edilerek gündeme getirilmesi ve Osmanlı Devleti'ne kabul ettirilmiş olması, konunun tarafı olan Büyük Güçlerin taleplerinin haklı olduğu anlamına gelmez. Modern uluslararası sistemin ve hukukun ürettiği mekanizmaların her şeye rağmen ciddi bir belirleyici olduğu günümüz dünyasında zorlayıcı diplomaside konunun taraflarının elini güçlendiren en önemli husus hukuka uygunluktur. Bununla birlikte, makalede ele alınan dönemde kendilerini uluslararası düzenin belirleyicileri olarak gören Büyük Güçler bu tür stratejileri yaptıkları çeşitli hukuksuz girişimlere adeta bir meşruiyet kazandırma aracı olarak kullanmışlar, hukuk ve adalet kavramları konunun tamamen dışında kalmıştır.

Hakem Değerlendirmesi: Dış bağımsız.

Çıkar Çatışması: Yazar çıkar çatışması bildirmemiştir.

Finansal Destek: Yazar bu çalışma için finansal destek almadığını beyan etmiştir.

Peer-review: Externally peer-reviewed.

Conflict of Interest: The author has no conflict of interest to declare.

Grant Support: The author declared that this study has received no financial support.

\section{Kaynakça/References}

Türkiye Cumhuriyeti Cumhurbaşkanlığı Devlet Arşivleri Başkanlığı Osmanlı Arşivi (BOA)

İrade-Hususî (İ.HUS).

Yildız Tasnifi

Esas Evrakı (YEE).

Perakende Evrakı Askerî Maruzat (Y.PRK.ASK).

Perakende Evrak, Tahrirât-1 Ecnebiyye ve Mâbeyn Mütercimliği (Y.PRK.TKM).

Perakende Evrakı Başkitabet Dairesi Maruzatı (Y.PRK.BŞK).

Perakende Evrakı Umumî (Y.PRK.UM).

Sadaret Evrakı Resmî Maruzat (Y.A.RES).

Sadaret Hususî Maruzat (Y.A.HUS).

\section{İngiliz Milli Arşivleri (The National Archives)}

Foreign Office (FO) 371-145.

Yayımlanmış Belgeler

Documents Diplomatiques Français (1871-1914), 2. Série (1901-1911), Tome VIII (29 Septembre 190515 Janvier 1906), Paris: Ministère des Affaires Étrangères. Commission de Publication des Documents Relatifs aux Origines de la Guerre de 1914.

Turkey. No. 1 (1906). Further Correspondence Respecting the Affairs of South-eastern Europe, 1906 [Cd. 2816], nr. 96. 


\section{Kitap ve Makaleler}

Aarbakke, Vemund, Ethnic Rivalry and the Quest for Macedonia, 1870-1913, East European Monographs Distributed by Columbia University Press, New York 2003.

Abdülhamid'in Kara Kutusu Arap İzzet Holo Paşa'nın Günlükleri, I, Eski yazıdan aktaran ve yayına hazırlayan: İbrahim Küreli, İş Bankası Kültür Yayınları, İstanbul 2019.

Adanır, Fikret, Makedonya Sorunu, Tarih Vakfı Yurt Yayınları, İstanbul 1996.

Aksu, Fuat, Türk Dış Politikasında Zorlayıcı Diplomasi, Bağlam Yayınları, İstanbul 2008.

Altınkaya, Emin İsmail, Hüseyin Hilmi Paşa'nın Hayatı ve Devlet Adamlığ (1855-1923), Akdeniz Üniversitesi Sosyal Bilimler Enstitüsü Yayımlanmamış Doktora Tezi, Antalya 2018.

Aydın, Mahir, "Arşiv Belgeleriyle Makedonya'da Bulgar Çete Faaliyetleri”, Osmanlı Araştırmaları, IX, İstanbul 1989, s. 209-234.

"Makedonya Meselesi ve Amerikalı Rahibenin Kaçırılması", Osmanlı Araştırmaları, XIII, İstanbul 1998, s. 239-258. , Şarkî Rumeli Vilayeti, Türk Tarih Kurumu Yayınları, Ankara 1992.

“Bahrî Nümayişlerin Tarihçesi”, Tanin, nr. 1564, 3 Ca. 1331 (10 Nisan 1913), s. 3.

Bayraktar, Kaya, Makedonya Sorunu ve Uluslararası Malî Komisyon (1902-1909), Birleşik Yayınevi, Ankara 2011.

Berridge, G. R. - Alan James, A Dictionary of Diplomacy, Palgrave Macmillan, New York 2001 (2. Bask1).

Beydilli, Kemal, "II. Abdülhamid Devrinde Makedonya Meselesine Dair", Osmanlı Araştırmaları, IX, İstanbul 1989, s. 77-98.

Brooks, Julian, Managing Macedonia: British Statecraft, Intervention, and 'Proto-peacekeeping' in Ottoman Macedonia, 1902-1905, Simon Fraser University, Faculty of Arts and Social Sciences, Department of History, Yayımlanmamış Doktora Tezi, British Columbia (Kanada) 2014.

Dakin, Douglas, The Unification of Greece, 1770-1923, New York 1972.

Gülsoy, Ersin, Girit'in Fethi ve Osmanlı İdaresinin Kurulması (1645-1670), Tarih ve Tabiat Vakfı Yayınları, İstanbul 2004.

Hacısalihoğlu, Mehmet, Jön Türkler ve Makedonya Sorunu (1890-1918), Tarih Vakfi Yurt Yayınları, İstanbul 2008.

Halil Halid, “İngiltere'de Balkan Komitesi ve Meslek, Mazi ve Müstakbeli”, Sirat-ı Müstakim, nr. 99 (15 Temmuz 1326,) s. 360.

İskifyeli, Zeynep - Özgür Tilbe, "Makedonya Meselesinde Osmanlı Devleti’nin Dış Basındaki Sesi: Rumeli Umumî Müfettişi Hüseyin Hilmi Paşa”, Çeşm-i Cihan: Tarih Kültür ve Sanat Araştırmaları E-Dergisi, IV/2, 2017, s. 27-48.

Jönsson, Christer, "Coercive Diplomacy", The Encyclopedia of Empire, Online kullanım (https://onlinelibrary. wiley.com/doi/epdf/10.1002/9781118885154.dip10402)

Julian Brooks, "A “Tranquilizing" Influence? British "Proto-Peacekeeping” in Ottoman Macedonia 19041905”, Peace and Change, XXXVI/2 (2011), s. 172-190

Kayaoğlu, Taceddin, Osmanlı Hâriciyesinde Gayr-i Müslimler (1852-1925), Türk Tarih Kurumu Yayınları, Ankara 2013.

Kırmızı, Abdulhamit, Avlonyalı Ferid Paşa. Bir Ömür Devlet, Klasik Yayınları, İstanbul 2014. 
Kissenger, Henry, A World Restored: Metternich, Castlereagh, and the Problem of Peace, 1812-1822, Friedland Books 2017.

Levy, Jack S., "Deterremce and Coercive Diplomacy: The Contributions of Alexander George", Political Psychology, XXIX/4 (2008), s. 537-552.

Meyer, Cristopher, Getting Our Way, 500 Years of Adventure and Intrigue: the Inside Story of British Diplomacy, Weidenfeld and Nicolson, London 2009.

Mufassal Hukuk-ı Düvel, Merhum Ali Şehbaz Efendi Hazretlerinin Takrir-i Âlileridi, Naşiri Mehmed Arif, İstanbul 1324.

Mufassal Osmanlı Tarihi, VI, metin ve ilaveler: Midhat Sertoğlu, İstanbul 1972.

Otte, T. G., The Foreign Office Mind. The Making of British Foreign Office Policy, 1865-1914, Cambridge University Press 2011.

Pakalın, Mehmed Zeki, Sicill-i Osmanî Zeyli, yay. haz. Gülbadi Alan, TTK Yayınları, Ankara 2008.

Palabıyık, Mustafa Serdar, "The Emergence of the Idea of 'International Law' in the Ottoman Empire before the Treaty of Paris (1856)", Middle Eastern Studies, L/2 (2014), s. 233-251.

Ponsonby, Arthur, "The Execution of Reforms: A Plea for A British Policy", The Balkan Question. The Present Condition of the Balkans and of European Responsibilities by Various Writers, ed. Luigi Villari, London 1905, s. 331-350.

Samardjiev, Bozhidar, "On the Role of Public Opinion in Great Britain Regarding the Reforms in European Turkey and the Idea of Autonomy of Macedonia in British Middle East Policy (1903-1908)", Etudes Balkaniques, 2002/2, Sofia 2002, s. 15-30.

Sayg1l1, Hasip, "Rumeli Müfettişliği Döneminde (1902-1908) Makedonya'da Yunan Komitecileri ve Osmanlı Devleti”, Güvenlik Stratejileri, 21, İstanbul 2015, s. 147-183.

Shaw, Stanford J., Shaw, Ezel Kural, History of the Ottoman Empire and Modern Turkey, II, Cambridge University Press, London-New York-Melbourne 1977.

Sowards, Steven W., Austria's Policy of Macedonian Reform, Columbia University Press, New York 1989.

Stuart, Brain, Mcbeth, Gunboat, Corruption, and Claims: Foreign Intervention in Venezuela, 1899-1908, Greenwood Press, Connecticut-London 2001.

Sur, Melda, Uluslararası Hukukun Esasları, Beta, İstanbul 2014 (8. Baskı).

The Times, 18 October 1905, s. 3.

Tokay, Gül, Makedonya Sorunu. Jön Türk İhtilalinin Kökenleri (1903-1908), Afa Yayınları, İstanbul 1996.

Ünver, Metin - Murat Hülkiender, II. Abdülhamid Dönemi Osmanlı Fransız İlişkilerinde Krizler ve Çatışmalar 1901 Hadisesi (Lorando-Tubini Meselesi), İlgi Kültür Sanat Yayınları, İstanbul 2018.

Yeşil, Fatih, “İstanbul Önlerinde Bir İngiliz Filosu: Uluslararası Bir Krizin Siyasî ve Askerî Anatomisi”, Nizâm-l Kadîm'den Nizâm-ı Cedîd'e III. Selim ve Dönemi, ed. Seyfi Kenan, İSAM Yayınları, İstanbul 2010, s. 391-493.

Yosmaoğlu-Turner, İpek, The Priest's Robe and the Rebel's Rifle: Communal Conflict and the Construction of National Identity in Ottoman Macedonia 1878-1908, Princton Üniversitesi Yayımlanmamış Doktora Tezi, 2005. 


\section{EK}

\section{Aristarki Bey'in Paris'te Journal Des Débats'da Yayınlanan Fransızca Makalesinin Tercümesi $^{182}$}

Birkaç günden beri Devlet-i Aliyye aleyhinde hareket-i mütekaddimede bulunacak veya buna iştirâk edecek olan devletlerin güya canib-i Hükûmet-i Seniyyeden ihlâl edilmiş birtakım hukuku müdafaaya mecbur imiş gibi hükûmet-i müşarun-ileyhaya karşı tedâbîr-i zecriye ittihazından bahsolunuyor. Maheza Avrupa'nın bu mesleğe sülûka meyyâl gibi göründüğü şu sırada ne sıfatla hareket ettiği ve Devlet-i Aliyye'nin kendisine isnâd olunan kabahatin hakikaten kendisine ait olup olmadığı cây-1 sualdir. Tedâbîr-i zecriye ittihazından evvel her devlete terettüb eden mes'uliyeti tayin etmek lazım gelir. Hükûmet-i Seniyye'nin şiddet-i müfritaları cihetiyle sahaif-i tevarihte bir misline tesadüf olunmayan Ayestafanos ve Berlin muahadenameleri ahkamından bir çoğunu kemal-i sıdk u ihlas ile icra etmiş olduğu halkça pek o kadar malum değildir. İmdi Hükûmet-i Seniyye fedâkârlıklar ihtiyar ettikçe, devletlerin en basit kavaid-i hakkaniyet-perverane ile uhdelerine terettüb eden vazife iktizasınca hükûmât-1 Balkaniyeyi kendilerine terettüb edip yine Berlin Muahadenamesi ahkamına tevfikan hükümat-1 mezkûreye bahşolunan hukuk-1 mülkiye ve saireye müteferri taahhüdatı da ifaya icbâr etmeleri lazım gelir idi. Şurası şayan-1 teessüfdür ki düvel-i muazzama bu yolda bir şey yapmadıktan başka muahede-i mezkûrenin güya canib-i Babıali'den henüz tamamıyla icra olunmayan iki maddesinin icrası taleb(in)de ssrâr etmektedirler. Bir taraftan bu cebr ü şiddet ve diğer taraftan bu müsaade ve müsamaha-i bi’n-nefs muahedenamelerin ma'mûliyetine îras-1 halel etmiştir. Çünkü her mukavelenamenin olduğu gibi bir muahedenamenin dahi bi'l-cümle ahkâmına mürâat olunmak lazım gelir. Aksi takdirde o muahedename mefsûh olur. Binaen-aleyh Babiali badema her gûne taahhüdâttan azâde bulunduğunu beyan ve ilan etmek hakkını haizdir. İş burada da kalmamıştır, düvel-i muazzamanın ikisi, Avrupa devletlerinin vekâletini haiz bulunmaksızın yalnız bazı mesâlihi için Devlet-i Aliyye ile icra-yı müzâkerâta mezuniyet-bahş eden Berlin Muahedenamesi'nde asla musarrah olmayan Mürzsteg Programını tanzime kıyam etmişlerdir. Hükûmet-i Seniyye bu programı kabulden imtina etmiş ve imtina-1 vakiinin esbâb-1 mucibesini de şerh ü izah eylemiş olduğu halde mezkûr program tehdidât-1 şedîde tahtında olarak yine kendisine tahmil edilince bir sebeb-i mücbir hükmünde bulunan bu ahvâle karşı kuyûd-1 ihtiraziye-i kat'iyye dermiyan ederek mutavaat göstermiş ve hükümet-i Balkaniyeden bazılarının eser-i ifsâdâtı olarak tahaddüs eden birtakım müşkilât ve mevani-i takat-berendezâne arasında mezkûr programın en büyük ve en mühim kısmını mevki-i icrâya vaz etmiş iken düvel-i muazzama ne muahedâtta ne de mezkur programda zikr olunmayan bir rakabe-i maliye tesisine kalkışmışlardır. Babıali maliye delegelerinin Selanik'e muvasalatlarından evvel bu tasavvurlarından feragat etmelerini devletlerden rica eylemiş ise de bir faide hasıl olmamıştır. İttihad-1 fikr esâsı bi'l-cümle

182 BOA, Y.A.Hus. 495/121, Lef 3. 
muahedât-1 müşterekenin cümle-i ahkâmından bulunmuş ve bin sekiz yüz yetmiş senesinde İngiltere ve Berlin Konferansı'nda dahi Kont "Şuvalof” tarafından tervîç edilmiş ve Mesâil-i Şarkiyye hakkında ise daima tatbîk olunagelmiş iken bin sekiz yüz yetmiş sekiz tarihinden beri Devlet-i Aliyyece mucib-i fevâid ve muhsinât olabileceği ahvalde lâyetegayyer bir surette nazar-1 itibâra alınmamıştır. Maheza bu esası bugün birden bire hukuk ve vak' u haysiyet-i hazret-i padişahiyi muhill bir murakabe-i maliye suretinde ve gayr-i meşru ve binaen-aleyh keyfi bir mahiyette tekrar meydana çıkarıyor. Bir de Babıali buna mutavaat etmediği takdirde kendisini tedâbîr-i zecriyeye maruz bırakacağı beyan olunuyor. Çünkü Avrupa devletleri nüfuz ve iktidarlarına bu derece îras-ı halel edilmesini tecvîz edemeyecektir. Yani tabir-i aherle Hükûmet-i Seniyye yalnız ahkâm-1 muahedata mürâata mecbur olduğu halde bu muahedâta muhâlif olarak kararlaştırılan bu derece elîm bir şeyin ve tarafeyn-i âkideynden yalnız biri cânibinden ihdas olunan bid'atin netayicine duçar olacaktır. Murakabe-i maliye bir ihtiyaca, bir lüzuma mübteni olsaydı yine bir dereceye kadar ma'zûr tutulabilir idi. Lakin Bank-1 Osmani’nin Fransız olan müdürü Mösyö Deffés Tan Gazetesine gönderdiği bir mektupta Bank-1 Osmani’nin Mösyö Şeyg tarafından tavsiye ve Mürsteg programında tasrîh olunan müdahalesinin suret-i muntazamada icra edildiğini ve canib-i Hükûmet-i Seniyyeden ibrâz olunan hulus-1 niyyet ve müsâraat sayesinde kaffe-i masarif-i idarenin tesviye olunduğu ve hatta fazlalar bile zuhur ettiği erkâm ile isbat eylemiştir. Fakat bu mütalaanın Devlet-i Aliyye ile olan münasebâtında Avrupa diplomasisinin mesleğince bir kaide ittihaz olunmuş gibi görünen hareket-i keyfiyeye karşı ne hükmü olabilir. 